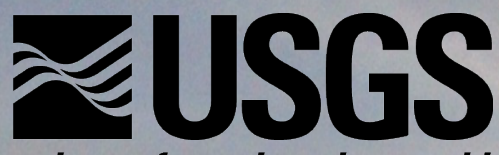

science for a changing world

\title{
U.S. Geological Survey Science for the Wyoming Landscape Conservation Initiative-2015 Annual Report
}

Open-File Report 2016-1141

U.S. Department of the interior U.S. Geological Survey 
Front cover photograph: Near the Jonah gas field at sunset. Photograph by Lindsey E. Sanders, University of Wyoming. Back cover Photograph by Jerrod Wheeler, U.S. Geological Survey, measures streamflow in the New Fork River as part of a study to evaluate changes along this segment of the river. Photo credit: Seth Davidson, U.S. Geological Survey. 


\section{U.S. Geological Survey Science for the Wyoming Landscape Conservation Initiative-2015 Annual Report}

By Zachary H. Bowen, Cameron L. Aldridge, Patrick J. Anderson, Timothy J. Assal, Timothy T. Bartos, Anna D. Chalfoun, Geneva W. Chong, Marie K. Dematatis, Cheryl A. Eddy-Miller, Steven L. Garman, Stephen S. Germaine, Collin G. Homer, Christopher C. Huber, Matthew J. Kauffman, Daniel J. Manier, Cynthia P. Melcher, Kirk A. Miller, Tamar Norkin, Lindsey E. Sanders, Annika W. Walters, Anna B. Wilson, Teal B. Wyckoff

Open-File Report 2016-1141

U.S. Department of the Interior

U.S. Geological Survey 


\section{U.S. Department of the Interior \\ SALLY JEWELL, Secretary}

\section{U.S. Geological Survey \\ Suzette M. Kimball, Acting Director}

U.S. Geological Survey, Reston, Virginia: 2016

For more information on the USGS—-the Federal source for science about the Earth,

its natural and living resources, natural hazards, and the environment-visit

http://www.usgs.gov/ or call 1-888-ASK-USGS (1-888-275-8747).

For an overview of USGS information products, including maps, imagery, and publications, visit http://store.usgs.gov/.

Any use of trade, firm, or product names is for descriptive purposes only and does not imply endorsement by the U.S. Government.

Although this information product, for the most part, is in the public domain, it also may contain copyrighted materials as noted in the text. Permission to reproduce copyrighted items must be secured from the copyright owner.

Suggested citation:

Bowen, Z.H., Aldridge, C.L., Anderson, P.J., Assal, T.J., Bartos, T.T., Chalfoun, A.D., Chong, G.W., Dematatis, M.K., Eddy-Miller, C.A., Garman, S.L., Germaine, S.S., Homer, C.G., Huber, C.C., Kauffman, M.J., Manier, D.J., Melcher, C.P., Miller, K.A., Norkin, Tamar, Sanders, L.E., Walters, A.W., Wilson, A.B., and Wyckoff, T.B., 2016, U.S. Geological Survey science for the Wyoming Landscape Conservation Initiative-2015 annual report: U.S. Geological Survey Open-File Report 2016-1141, 59 p., http://dx.doi.org/10.3133/ofr20161141.

ISSN 2331-1258 (online) 


\section{Contents}

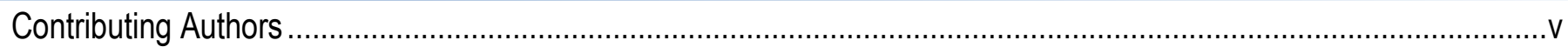

Conversion Factors............................................................................................................................. vii

Common and Scientific Names of Species in this Report.................................................................................. vii

Abbreviations Used in this Report...............................................................................................................iii

Acknowledgments.................................................................................................................................... vii

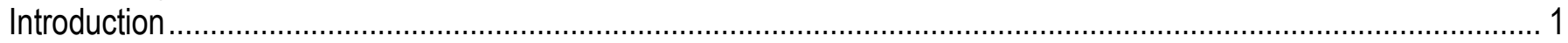

Towards Understanding and Mitigating Effects of Land-Use Changes in Southwestern Wyoming........................... 1

The U.S. Geological Survey: Scientific Arm of the Wyoming Landscape Conservation Initiative ............................... 5

A Landscape-Scale Initiative Requires a Multidisciplinary Team of Scientists.................................................. 5

Identifying and Prioritizing USGS Science and Technology Activities ........................................................... 6

Using a Three-Tiered Approach for Building a Solid Foundation for Management and Science ......................... 12

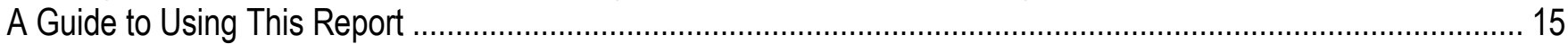

Icons Used to Identify Existing and Potential Applications of Individual USGS WLCI Science Projects............... 16

Highlights of FY2015 USGS WLCI Science Accomplishments..................................................................... 17

The 2015 Joint Science Conference: A Collaboration between the Wyoming Chapter of The Wildlife Society

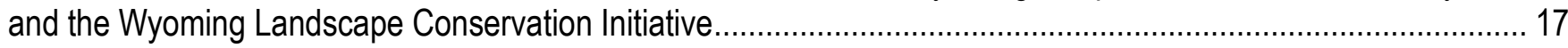

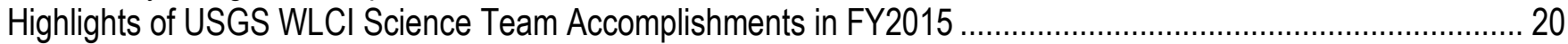

Highlights of FY2015 Baseline Synthesis Accomplishments: Supporting WLCI Planning and Decisionmaking with Data Compilation and Landscape-Scale Assessment Tools ................................................................. 20

Highlights of FY2015 Targeted Monitoring and Research Accomplishments: Assessing Status and Trends of Terrestrial and Aquatic Systems, Effectiveness of On-the-Ground Habitat Projects, and Wildlife

Responses to Energy Resource Development....................................................................................... 22

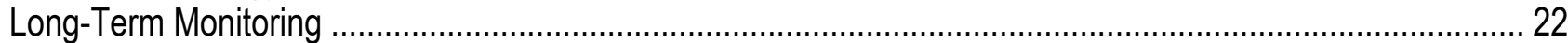

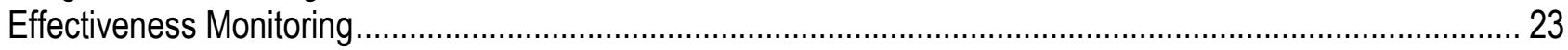

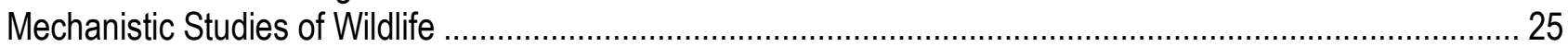

Data and Information Management Accomplishments: Providing a Web-Based Infrastructure for Managing

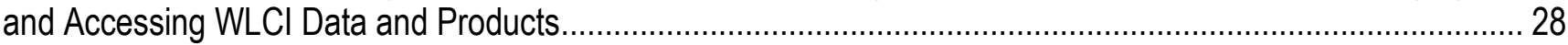

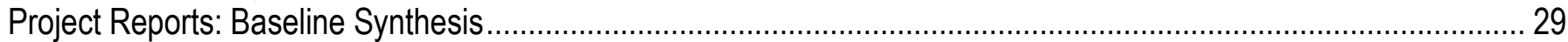

Application of Comprehensive Assessment to Support Decisionmaking and Conservation Actions ....................... 29

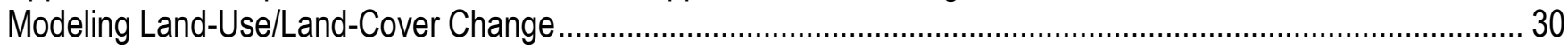

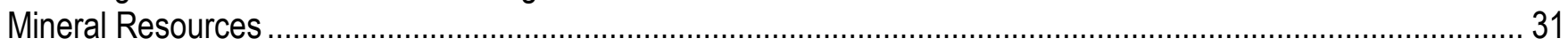

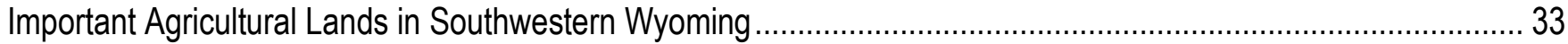

Project Reports: Long-Term Monitoring.................................................................................................. 34

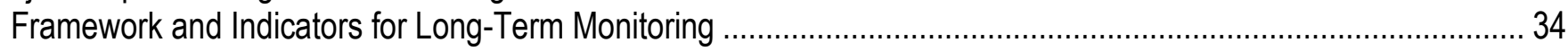

Time-Series Analysis of Multi-Resolution Imagery to Quantify Sagebrush Defoliation and Mortality in

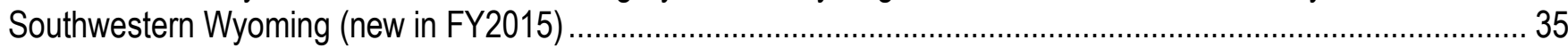

Remote Sensing and Vegetation Inventory and Monitoring ……................................................................ 37

Long-Term Monitoring of Surface Water, Groundwater, and Water Quality ...................................................... 38

Analysis of Long-term Groundwater Elevation Data and Geologic Description.................................................. 40

Evaluation of Groundwater Interaction with Small Streams in the Western Green River Basin to Enhance

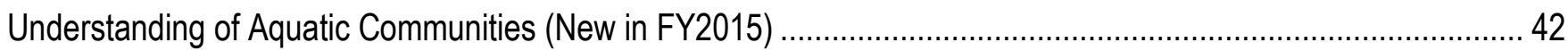

Project Reports: Effectiveness Monitoring ............................................................................................... 44

Applying Greenness Indices to Evaluate Sagebrush in the WLCI Region ........................................................ 44

Mapping Mixed Mountain Shrub Communities to Support WLCl Conservation Planning and Effectiveness

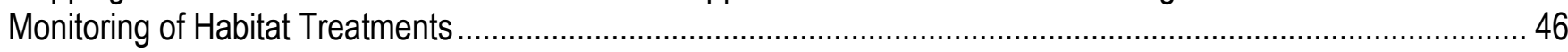




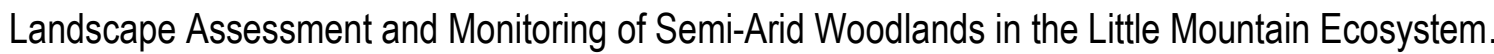

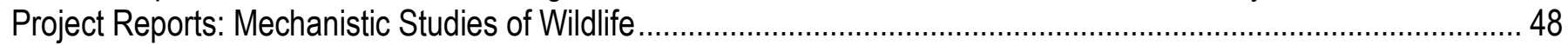

Modeling Habitat Associations and Distribution of Pygmy Rabbits ................................................................. 48

Modeling Greater Sage-Grouse Population Responses to Landscape Changes............................................. 49

Mechanistic Understanding of Energy Resource Development Effects on Songbirds .....................................5 50

Identifying Threshold Levels of Development that Impede Wyoming Mule Deer Migrations ................................. 51

Influence of Energy Resource Development on Native Fish Communities ...................................................5 52

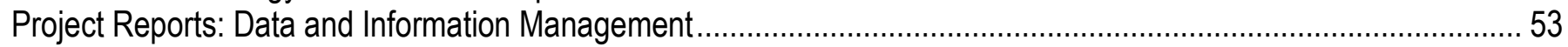

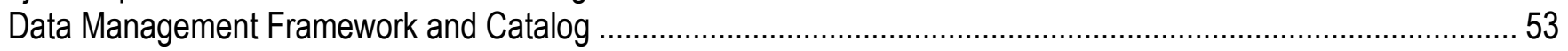

Outreach and Graphic Products: Web Application Development for Data Visualization ......................................5 54

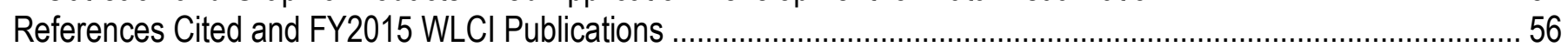

\section{Figures}

1. The boundary and major features of the Wyoming Landscape Conservation Initiative ................................... 2

2. The U.S. Geological Survey's framework for guiding assessment, monitoring, and research of ecosystem components .................................................................................................................................. 13

3. Locations of U.S. Geological Survey's study areas, including mineralized areas, associated with Baseline Synthesis activities in the Wyoming Landscape Conservation Initiative region .............................................. 31

4. Long-abandoned phosphate mine sites near Cokeville, Wyoming ............................................................... 32

5. Important agricultural lands index score results for the Wyoming Landscape Conservation Initiative ................ 33

6. The study area is centered on the western portion of Sweetwater County, southern Sublette County, and

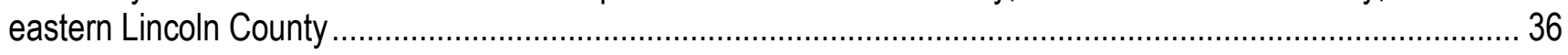

7. Change in percent cover of sagebrush across the Wyoming Landscape Conservation Initiative region from

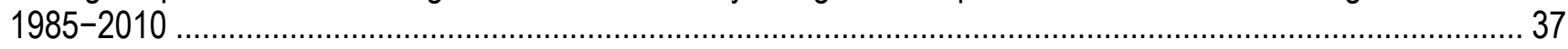

8. Locations of U.S. Geological Survey's field-based study areas associated with Long-Term Monitoring projects during FY2015 in the Wyoming Landscape Conservation Initiative region......................................... 38

9. Elevation of New Fork River and associated streambank well from April 1 to September 30, 2015..................39

10. Lines of equal water-level elevation and general direction of groundwater flow in the upper Tertiary Aquifer, in and near the Normally Pressured Lance project boundary

11. Study area and study streams for evaluating the influence of energy resource development on native fish communities

12. Locations of the U.S. Geological Survey's FY2015 field-based study areas associated with Effectiveness Monitoring activities and Mechanistic Studies of Wildlife in the Wyoming Landscape Conservation Initiative region.

13. The instantaneous rate of greenup is an indicator of forage quality...

14. Digitized mountain shrub patches in the Big Piney-La Barge area

15. Mule deer use of migration stopover sites before and after rapid increase in development of a natural gas field in southwestern Wyoming

16. Screenshot showing one of the interactive energy maps on the WLCl web site. 


\section{Tables}

1. Major management needs and objectives identified by partners of the Wyoming Landscape Conservation Initiative during workshops and meetings prior to initiative implementation....

2. Summary of U.S. Geological Survey science and technical development projects conducted in Fiscal Year 2015 for the Wyoming Landscape Conservation Initiative

3. Presentations and posters given at the December 2015 Wyoming Landscape Conservation Initiative Science Workshop by U.S. Geological Survey scientists involved with WLCl projects

4. Products of 2015 work on long-term monitoring or surface water, groundwater, and water quality

\section{Contributing Authors}

Cameron L. Aldridge

Colorado State University, Natural Resource Ecology Laboratory, contracted to U.S. Geological Survey, Fort Collins Science Center, Fort Collins, Colo.

Patrick J. Anderson

U.S. Geological Survey, Fort Collins Science Center, Fort Collins, Colo.

Timothy J. Assal

U.S. Geological Survey, Fort Collins Science Center, Fort Collins, Colo.

Timothy T. Bartos

U.S. Geological Survey, Wyoming-Montana Water Science Center, Cheyenne, Wyo.

Zachary H. Bowen

U.S. Geological Survey, Fort Collins Science Center, Fort Collins, Colo.

Anna D. Chalfoun

U.S. Geological Survey Wyoming Cooperative Fish and Wildlife Research Unit, Dept. of Zoology and Physiology, University of Wyoming, Laramie, Wyo.

Geneva W. Chong

U.S. Geological Survey, Northern Rocky Mountain Science Center, Jackson, Wyo.

Marie K. Dematatis

Cherokee Nations Technologies, contracted to U.S. Geological Survey, Fort Collins Science Center, Fort Collins, Colo.

Cheryl A. Eddy-Miller

U.S. Geological Survey, Wyoming-Montana Water Science Center, Cheyenne, Wyo. 
Steven L. Garman

U.S. Geological Survey, Geosciences and Environmental Change Science Center, Denver, Colo.

Stephen S. Germaine

U.S. Geological Survey, Fort Collins Science Center, Fort Collins, Colo.

Collin G. Homer

U.S. Geological Survey, Earth Resources Observation and Science Center, Sioux Falls, S.Dak.

Christopher C. Huber

U.S. Geological Survey, Fort Collins Science Center, Fort Collins, Colo.

Matthew J. Kauffman

U.S. Geological Survey, Wyoming Cooperative Fish and Wildlife Research Unit, Dept. of Zoology and Physiology, University of Wyoming, Laramie, Wyo.

Daniel J. Manier

U.S. Geological Survey, Fort Collins Science Center, Fort Collins, Colo.

Cynthia P. Melcher

U.S. Geological Survey, Fort Collins Science Center, Fort Collins, Colo.

Kirk A. Miller

U.S. Geological Survey, Wyoming-Montana Water Science Center, Cheyenne, Wyo.

Tamar Norkin

U.S. Geological Survey, Core Science Analytics and Synthesis and Libraries, Denver, Colo.

Lindsey E. Sanders

Wyoming Cooperative Fish and Wildlife Research Unit, Dept. of Zoology and Physiology, University of Wyoming, Laramie, Wyo.

Annika W. Walters

U.S. Geological Survey, Wyoming Cooperative Fish and Wildlife Research Unit, Dept. of Zoology and Physiology, University of Wyoming, Laramie, Wyo.

Anna B. Wilson

U.S. Geological Survey, Central Mineral and Environmental Resources Science Center, Denver, Colo.

Teal B. Wyckoff

Wyoming Cooperative Fish and Wildlife Research Unit, Dept. of Zoology and Physiology, University of Wyoming, Laramie, Wyo. 


\section{Conversion Factors}

International System of Units to Inch/Pound

\begin{tabular}{lcl}
\hline & \multicolumn{1}{c}{ Multiply } & \multicolumn{1}{c}{ To obtain } \\
\hline meter $(\mathrm{m})$ & Length & \\
kilometer $(\mathrm{km})$ & 3.281 & foot $(\mathrm{ft})$ \\
meter $(\mathrm{m})$ & 0.6214 & mile $(\mathrm{mi})$ \\
\hline & 1.094 & yard $(\mathrm{yd})$ \\
\hline cubic meter $\left(\mathrm{m}^{3}\right)$ & Area & \\
\hline square kilometer $\left(\mathrm{km}^{2}\right)$ & 35.31 & cubic foot $\left(\mathrm{ft}^{3}\right)$ \\
\hline
\end{tabular}

\section{Common and Scientific Names of Species in this Report}

\begin{tabular}{llll}
\hline Common name & Scientific name & Common name & Scientific name \\
\hline American badger & Taxidea taxus & Mountain sucker & Catostomus platyrhynchus \\
Antelope bitterbrush & Purshia tridentata & Mottled sculpin & Cottus bairdii \\
Aspen & Populus tremuloides & Mule deer & Odocoileus hemionus \\
Brewer's sparrow & Spizella breweri & Pronghorn & Antilocapra americana \\
Cheatgrass & Bromus tectorum & Pygmy rabbit & Brachylagus idahoensis \\
Chipmunk & Tamias minimus & Sage thrasher & Oreoscoptes montanus \\
Chokecherry & Prunus virginiana & Sagebrush sparrow & Artemisiospiza nevadensis \\
Currant species & Ribes spp. & Sagebrush species & Artemisia spp. \\
Cutthroat trout & Oncorhynchus clarki & Serviceberry & Amelanchier alnifolia \\
Curl-leaf mahogany & Cercocarpus ledifolius & Snowberry & Symphoricarpos spp. \\
Deer mouse & Peromyscus maniculatus & Sumac species & Rhus spp. \\
Elk & Cervus canadensis & Thirteen-lined ground squirrel & Ictidomys tridecemlineatus \\
Gooseberry species & Ribes spp. & Uinta ground squirrel & Urocitellus armatus \\
Greater sage-grouse & Centrocercus & Willow species & Salix spp. \\
& urophasianus & & \\
Mountain mahogany & Cercocarpus montanus & & \\
\hline
\end{tabular}




\section{Abbreviations Used in this Report}

$\begin{array}{ll}\text { BLM } & \text { U.S. Bureau of Land Management } \\ \text { FY } & \text { fiscal year (for example, Federal FY2014 was October 1, 2014 through September 30, 2015) } \\ \text { IA } & \text { Integrated Assessment (for the Wyoming Landscape Conservation Initiative) } \\ \text { IAMD } & \text { Interagency Monitoring Database } \\ \text { IAMT } & \text { Interagency Monitoring Team } \\ \text { LME } & \text { Little Mountain Ecosystem } \\ \text { LPDT } & \text { Local Project Development Team } \\ \text { NRCS } & \text { Natural Resources Conservation Service } \\ \text { USGS } & \text { U.S. Geological Survey } \\ \text { WGFD } & \text { Wyoming Game and Fish Department } \\ \text { WLCI } & \text { Wyoming Landscape Conservation Initiative }\end{array}$

\section{Acknowledgments}

The authors thank the Wyoming Landscape Conservation Initiative's Science and Technical Advisory Committee and the Coordination Team for their ideas and advice regarding this report, and the authors acknowledge the Wyoming Game and Fish Department and the U.S. Bureau of Land Management for supporting the U.S. Geological Survey's WLCI efforts by providing data and other information. The authors also wish to thank Chris Potter and Holly Miller, both U.S. Geological Survey, for their thorough reviews. Finally, the authors also wish to acknowledge Robert R. McDougal, 1955-2016, for his contributions to our collective knowledge of Muddy Creek and soils of the southwestern Wyoming

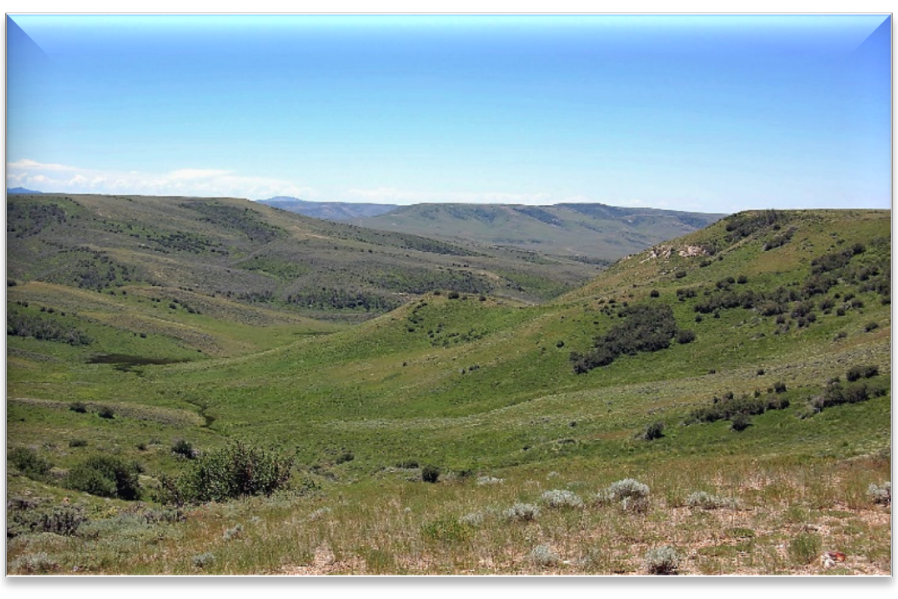

Muddy Creek headwaters. Photograph by Robert McDougal, U.S. Geological Survey.

Landscape. He will be missed. 


\title{
U.S. Geological Survey Science for the Wyoming Landscape Conservation Initiative-2015 Annual Report
}

\author{
By Zachary H. Bowen, Cameron L. Aldridge, Patrick J. Anderson, Timothy J. Assal, Timothy T. Bartos, Anna D. \\ Chalfoun, Geneva W. Chong, Marie Dematatis, Cheryl A. Eddy-Miller, Steven L. Garman, Stephen S. Germaine, \\ Collin G. Homer, Christopher Huber, Matthew J. Kauffman, Daniel J. Manier, Cynthia P. Melcher, Kirk A. Miller, \\ Tamar Norkin, Lindsey E. Sanders, Annika W. Walters, Anna B. Wilson, and Teal B. Wyckoff
}

\section{Introduction}

\section{Towards Understanding and Mitigating Effects of Land-Use Changes in Southwestern Wyoming}

Southwestern Wyoming is endowed with abundant wildlife, stunning landscapes, and important economies based on recreation, ranching, and farming. It is also a region of abundant energy resources, including oil, gas, coal, wind, and solar, which are helping to meet our Nation's increasing energy demands and contribute to the local economy. Energy resource development has been a significant component of land use in southwestern Wyoming for decades, but since the early 2000s it has been rapidly expanding and diversifying to include new technologies for extracting unconventional oil and gas and tapping renewable resources. Development to support the accompanying increase in human population also has been accelerating across the region.

With southwestern Wyoming's rapid land-use changes, concerns about potential negative effects on the region's wildlife populations, water and air resources, and agricultural- and recreation-based economies have intensified. To address these concerns, the Wyoming Landscape Conservation Initiative (WLCI) was established in 2007 by the U.S. Geological Survey (USGS) and public agencies with jurisdiction over land and (or) natural resources in southwestern Wyoming (fig. 1). The associated memorandum of understanding between WLCI partner agencies outlines the initiative's mission, objectives, organization, and partner roles (see https://www.wlci.gov/partners and https:/www.wlci.gov/content/management-documents for more information).

\section{Mission Statement of the Wyoming Landscape Conservation Initiative}

Implement a long-term, science-based program to assess and enhance the quality and quantity of aquatic and terrestrial habitats at a landscape scale in Southwest Wyoming while facilitating responsible development through local collaboration and partnerships. 


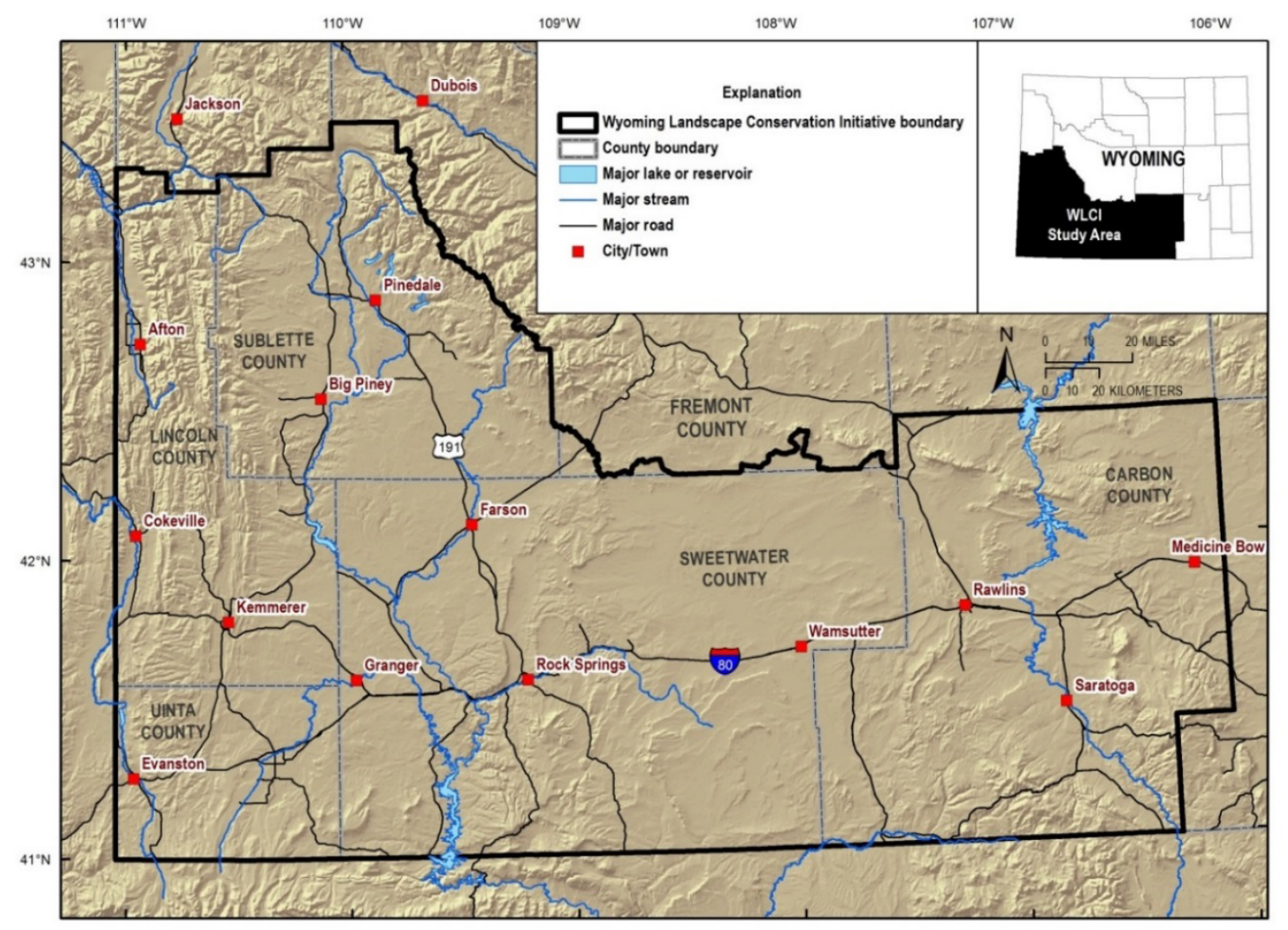

Figure 1. The boundary and major features of the Wyoming Landscape Conservation Initiative (WLCl).

Prior to WLCI implementation, a series of scoping meetings and workshops were held to identify potential WLCI partners, establish leadership teams, and identify major management needs and objectives for the WLCI region (table 1) (D'Erchia, 2008). Participants also identified five focal (priority) habitats and wildlife Species of Greatest Conservation Need (Wyoming Game and Fish Department, 2010) that would be central to WLCI-funded activities. The six management needs and objectives fell into four broad themes listed below.

- Identify and assess the cumulative environmental effects (current and future) associated with energy resource development and other major drivers of landscape change.

- Develop methods for efficient, effective monitoring of ecosystem conditions across a vast and heterogeneous landscape.

- Evaluate the efficacy of habitat enhancement and restoration projects in meeting objectives.

- Develop the tools for housing, displaying, and disseminating data and other information to support planning and decisionmaking for conserving ecosystem function and integrity in the WLCI region.

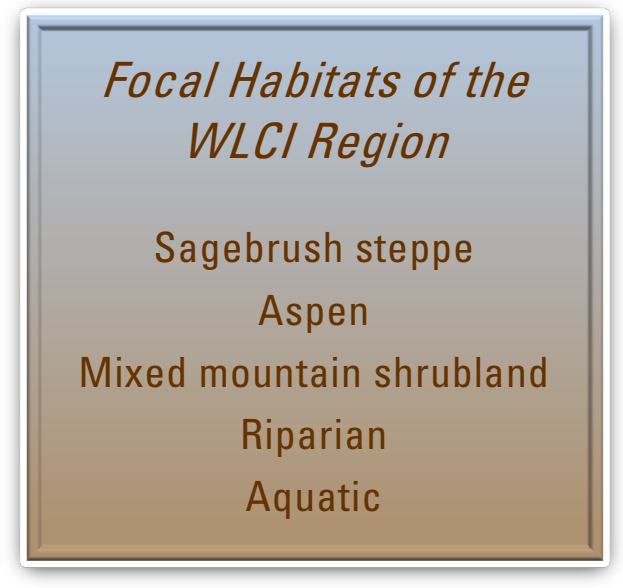


Table 1. Major management needs and objectives identified by partners of the Wyoming Landscape Conservation Initiative (WLCl) during workshops and meetings prior to initiative implementation.

\begin{tabular}{|c|c|}
\hline Management Need & Objectives \\
\hline $\begin{array}{l}\text { 1. Identify key } \\
\text { drivers of change }\end{array}$ & $\begin{array}{l}\text { A. Identify, quantify, and prioritize key drivers of change, including interactive drivers and those measured inadequately in the past, such } \\
\text { as energy-development footprints over time (including initial surficial disturbance and associated short-/long-term disturbances, fire, } \\
\text { invasive species, livestock grazing). } \\
\text { B. Develop new methods or improve/refine models for predicting potential changes in key drivers over time and projecting likely future } \\
\text { responses to them. } \\
\text { C. Improve predictive capabilities of future scenario models, update scientific understanding of the origin/occurrence of energy/mineral } \\
\text { resources based on most current information for viable deposit types/assessment units. } \\
\text { D. Develop methods to assess full costs (exploration, extraction, use) of energy/mineral development. }\end{array}$ \\
\hline $\begin{array}{l}\text { Identify } \\
\text { condition and } \\
\text { distribution of } \\
\text { key wildlife } \\
\text { species/habitats, } \\
\text { and species } \\
\text { habitat } \\
\text { requirements }\end{array}$ & $\begin{array}{l}\text { A. Identify key aquatic/terrestrial species or assemblages (including indicator, umbrella, socially/economically important, or special status } \\
\text { species). } \\
\text { B. Assess baseline conditions and determine landscape-level habitat requirements for important aquatic/terrestrial species (special status, } \\
\text { keystone, economically/socially important). } \\
\text { C. Use Wyoming Game and Fish Department's Strategic Habitat Plan as a foundation to delineate spatiotemporal habitat distribution, map } \\
\text { key/high-quality habitats for key species/assemblages. } \\
\text { D. Identify key areas of conservation concern/priority by mapping important, sensitive, and rare habitats, critical habitats (including } \\
\text { nesting, rearing, wintering, spawning, migration) required for long-term persistence of key wildlife species. } \\
\text { E. Identify vulnerability/sensitivity of key habitats/areas to key drivers of change. } \\
\text { F. Relate habitat characteristics to animal distribution/population dynamics (an index of habitat quality) to assess effects of key drivers of } \\
\text { change on aquatic/terrestrial wildlife/habitats. }\end{array}$ \\
\hline $\begin{array}{l}\text { 3. Evaluate wildlife } \\
\text { and livestock } \\
\text { responses to } \\
\text { development }\end{array}$ & $\begin{array}{l}\text { A. Evaluate direct effects of energy development and other major drivers on physiology/demographic performance of wildlife (individual } \\
\text { species and species groups) and livestock. } \\
\text { B. Evaluate indirect effects of habitat alteration on wildlife/livestock from invasive non-native plants, altered disturbance regimes, } \\
\text { increased susceptibility to disease, altered social dynamics, or other changes. } \\
\text { C. Assess different patch-size needs/edge effects that influence wildlife behavior and population structure/growth. } \\
\text { D. Develop methods to assess influence of energy development on livestock-management systems. }\end{array}$ \\
\hline
\end{tabular}

4. Evaluate the effectiveness of restoration, reclamation, and mitigation

A. Evaluate effectiveness of specific habitat improvement/restoration practices in different habitat types/precipitation zones.

B. Evaluate/guide refinement of Best Management Practices.

C. Evaluate relationships between observed resource responses and management activities (restoration, reclamation, and habitatimprovement projects).

activities

D. Design a framework for objectively developing the most effective restoration/enhancement projects on a landscape scale. 
Table 1. Major management needs and objectives identified by partners of the Wyoming Landscape Conservation Initiative (WLCl) during workshops and meetings prior to initiative implementation.-Continued

\begin{tabular}{|c|c|}
\hline Management Need & Objectives \\
\hline $\begin{array}{l}\text { 5. Develop an } \\
\text { integrated } \\
\text { inventory and } \\
\text { monitoring } \\
\text { strategy }\end{array}$ & $\begin{array}{l}\text { A. Develop inventory/monitoring approach designed to evaluate overall effectiveness of WLCI [on-the-ground habitat projects] and } \\
\text { support assessment of cumulative effects. } \\
\text { B. Coordinate with WLCI partners to establish landscape-scale monitoring strategies/protocols. } \\
\text { C. Integrate WLCI inventory/monitoring programs with other local, State, and Federal efforts. } \\
\text { D. Make inventory/monitoring information accessible to WLCI partners/resource managers through data-management framework/data } \\
\text { clearinghouse. } \\
\text { E. Integrate inventory/monitoring efforts into an adaptive management framework. }\end{array}$ \\
\hline $\begin{array}{l}\text { 6. Develop a data } \\
\text { clearinghouse } \\
\text { and information } \\
\text { management } \\
\text { framework }\end{array}$ & $\begin{array}{l}\text { A. Develop a Web-based WLCI information clearinghouse that can protect confidential, sensitive, and (or) proprietary information. } \\
\text { B. Develop/implement a project tracking/database system to provide summaries of habitat projects and associated spatial data. } \\
\text { C. Provide data-management, visualization (mapping), and decision-support tools for WLCI. } \\
\text { D. Provide public information/outreach on WLCI habitat improvement/science activities. }\end{array}$ \\
\hline
\end{tabular}




\section{The U.S. Geological Survey: Scientific Arm of the Wyoming Landscape Conservation Initiative}

\section{A Landscape-Scale Initiative Requires a Multidisciplinary Team of Scientists}

The U.S. Geological Survey (USGS) represents the science and technical support arm of the WLCI effort. As such, the USGS WLCI Science Team (hereafter Science Team) is responsible for building the scientifically defensible foundation of knowledge on which WLCI planners, decisionmakers, and resource managers may base their WLCI activities, including on-the-ground habitat restoration and enhancement projects, setting aside conservation lands, policymaking, and more. An effort of this scale demands expertise from a wide variety of disciplines. To meet these demands, we have assembled a Science Team composed of terrestrial and aquatic ecologists; energy and mineral geologists; hydrologists; socioeconomic scientists; geographers; specialists in remote sensing, geographic information systems, and geospatial analysis; and technologists.

\section{Roles of the U.S. Geological Survey for the WLCI}

- The USGS provides a multidisciplinary team composed of more than 25 scientists and technological experts (hereafter, "Science Team"). The Science Team conducts science and develops tools that help to inform and support WLCI partner planning, decisionmaking, and on-the-ground management actions. Results of USGS science also serve as building blocks for future science projects. The Science Team also leverages the value of its work by integrating the approaches and results of its many disciplines to enhance the scope and depth of its assessments, monitoring, and research capacities and products.

- The USGS provides leadership for the Interagency Monitoring Team.

- The USGS provides a liaison to the WLCI Coordination Team to

- facilitate coordination, communication, and activities among WLCI partners;

- help partners with integrating new information and technologies in their planning, decisionmaking, and management actions; and

- facilitate dissemination, interpretation, and use of U.S. Geological Survey findings, products, and tools.

The Science Team also provides leadership and guidance to the WLCI Interagency Monitoring Team (IAMT). This team is composed of WLCI partner representatives and is cochaired by two USGS scientists, Daniel Manier and Stephen Garman, who provide scientific expertise on monitoring issues, designs, methods, and emerging technologies. The IAMT was developed at the request of the WLCI Executive Committee and the Science and Technical Advisory Committee to gather information, 
provide summaries, and consult and coordinate with stakeholders on matters related to resource monitoring for the WLCI region. The primary foci of the IAMT have been to identify, mine/acquire, and organize data in a centralized Interagency Monitoring Database (IAMD); analyze data and other information from past and current WLCI monitoring activities; and communicate with WLCI leadership teams to share and incorporate results of data analyses and adapt the database framework as needed. The IAMT continuously gathers additional information and updates the IAMD through ongoing and new monitoring activities. Information on IAMT activity is accessible through the monitoring page of the WLCI Web site at https://www.wlci.gov/monitoring.

Finally, the Science Team includes a liaison to the WLCI Coordination Team. Our liaison, Patrick Anderson, helps to facilitate communications among and coordinate activities conducted by WLCI partners. He also helps to ensure that results and products of USGS science are taken into consideration or fully integrated into partner management actions and best management practices. Finally, the USGS liaison helps to ensure that USGS science addresses emerging management needs and priorities among WLCI partners.

\section{Identifying and Prioritizing USGS Science and Technology Activities}

The preimplementation scoping process for the WLCI culminated with a collaborative effort between the USGS and other WLCI partners to specify short- and long-term science activities for addressing each WLCI management objective. The management needs, with their objectives and proposed science activities, were published in the USGS Science Strategy for the WLCI (Bowen, Aldridge, Anderson, Chong, and others, 2009), which serves as a primary means of identifying and prioritizing USGS WLCI science and associated technological support activities. The direction of USGS science is evaluated annually and further refined or adjusted as needed through meetings with the WLCI leadership responsible for overseeing and guiding the WLCI effort, including the WLCI Executive Committee, Coordination Team, Science and Technical Advisory Committee, Steering Committee, Local Project Development Teams (LPDTs), and the IAMT. Each year, the Science and Technical Advisory Committee, Steering Committee, and LPDTs also meet to identify WLCI habitat enhancement and restoration priorities for the following year. Although the USGS does not conduct habitat enhancement projects, the Science Team tailors its effectiveness monitoring activities to ascertain the efficacy of these management actions. Overall, the iterative process of review and refinement helps to ensure that USGS science remains highly relevant to WLCI partner needs, changing conditions, and the implications of emerging knowledge and technologies.

The Science Team has made substantial progress on or completed a majority of the initially

proposed science activities (table 2). As new information is gained and new technologies are developed, some of the ongoing activities have benefited from retooling or a shift in emphasis, and new activities have been implemented to reflect emerging needs or priorities, and new lines of inquiry. Indeed, the Science Team has been highly successful at developing long-term, tiered research studies that first fill basic data gaps and (or) incorporate technological advances to maximize the scope, resolution, and accuracy of information gained. From the information gained in these earlier studies, new questions (hypotheses) have emerged and are being tested to answer increasingly fine-grained questions about exactly what drives changes on the landscape and exactly how and why species respond to those changes. By using this classic step-by-step scientific method, the Science Team is laying a solid and highly defensible foundation for management and future science, both within the WLCI and beyond. 
Table 2. Summary of U.S. Geological Survey science and technical development projects conducted in Fiscal Year (FY) 2015 for the Wyoming Landscape Conservation Initiative (WLCI). For each project, the WLCI management needs and objectives addressed (directly or indirectly) by the project are listed by alphanumeric codes that correspond to management needs and associated objectives listed in table 1 (for example, $1 \mathrm{~A}$ is Management Need 1, objective A). The summary also includes project status as of September 30, 2015, focal species and (or) habitats addressed by the project, and intended or potential applications of project outcomes (such as products, databases, models, or Web tools). Activity titles and page numbers are hypelinked so that users may go directly to the individual project reports for activities of particular interest.

\begin{tabular}{|c|c|c|c|c|c|}
\hline $\begin{array}{l}\text { Management } \\
\text { needs/objectives } \\
\text { addressed }\end{array}$ & Project title & $\begin{array}{l}\text { Status at } \\
\text { end of } \\
\text { FY2015 }\end{array}$ & $\begin{array}{l}\text { Focal species and (or) } \\
\text { habitat }\end{array}$ & $\begin{array}{l}\text { Intended and potential } \\
\text { applications of project outcomes }\end{array}$ & Page no. \\
\hline \multicolumn{6}{|c|}{ Baseline Synthesis activities } \\
\hline $\begin{array}{l}\text { 1A-C; } \\
2 \mathrm{~A}-\mathrm{F} ; 3 \mathrm{~A} ; 5 \mathrm{D}\end{array}$ & $\begin{array}{l}\text { Application of comprehensive } \\
\text { assessment to support decision- } \\
\text { making and conservation actions; } \\
\text { integrated assessment }\end{array}$ & Ongoing & $\begin{array}{l}\text { Any species and focal } \\
\text { habitat in WLCI study } \\
\text { area }\end{array}$ & $\begin{array}{l}\text { Status \& trends, science } \\
\text { foundation, policy/outreach }\end{array}$ & 29 \\
\hline$\underset{5 \mathrm{~A}}{1 \mathrm{~A}-\mathrm{C} ; 2 \mathrm{~A}-\mathrm{B}, \mathrm{F} ; 3 \mathrm{~A} ;}$ & Modeling land-use/land-cover change & Ongoing $^{1}$ & $\begin{array}{l}\text { Greater sage-grouse, } \\
\text { pygmy rabbit, mule deer; } \\
\text { all focal habitats }\end{array}$ & $\begin{array}{l}\text { Status \& trends, policy/outreach, } \\
\text { energy resource development }\end{array}$ & 30 \\
\hline $1 \mathrm{~A}-\mathrm{C} ; 2 \mathrm{~B}, \mathrm{~F}$ & Assessing energy resources & Ongoing $^{2}$ & N/A & $\begin{array}{l}\text { Science foundation, } \\
\text { policy/outreach, energy } \\
\text { resource development }\end{array}$ & \\
\hline $1 \mathrm{~A}-\mathrm{C} ; 2 \mathrm{~B}, \mathrm{~F}$ & Mineral resources & Ongoing & N/A & $\begin{array}{l}\text { Science foundation, } \\
\text { policy/outreach, energy } \\
\text { resource development }\end{array}$ & 31 \\
\hline $\begin{array}{l}\text { 1A, D; 2B; 3A-B,C; 4B } \\
5 \mathrm{~A}, \mathrm{C}-\mathrm{D}\end{array}$ & $\begin{array}{l}\text { Important agricultural lands in } \\
\text { southwestern Wyoming }\end{array}$ & Completed $^{3}$ & $\mathrm{~N} / \mathrm{A}$ & $\begin{array}{l}\text { Science foundation, } \\
\text { policy/outreach }\end{array}$ & 33 \\
\hline
\end{tabular}


Table 2. Summary of U.S. Geological Survey science and technical development projects conducted in Fiscal Year (FY) 2015 for the Wyoming Landscape Conservation Initiative (WLCl). For each project, the WLCl management needs and objectives addressed (directly or indirectly) by the project are listed by alphanumeric codes that correspond to management needs and associated objectives listed in table 1 (for example, $1 \mathrm{~A}$ is Management Need 1, objective A). The summary also includes project status as of September 30, 2015, focal species and (or) habitats addressed by the project, and intended or potential applications of project outcomes (such as products, databases, models, or Web tools). Activity titles and page numbers are hypelinked so that users may go directly to the individual project reports for activities of particular interest.-Continued

\begin{tabular}{|c|c|c|c|c|c|}
\hline $\begin{array}{l}\text { Management } \\
\text { needs/objectives } \\
\text { addressed }\end{array}$ & Project title & $\begin{array}{l}\text { Status at } \\
\text { end of } \\
\text { FY2015 }\end{array}$ & $\begin{array}{l}\text { Focal species and (or) } \\
\text { habitat }\end{array}$ & $\begin{array}{l}\text { Intended and potential } \\
\text { applications of project outcomes }\end{array}$ & Page no. \\
\hline \multicolumn{6}{|c|}{ Long-Term Monitoring activities } \\
\hline $\begin{array}{l}2 \mathrm{~A}-\mathrm{F} ; 2 \mathrm{~A}-\mathrm{B} ; 3 \mathrm{~A}-\mathrm{C} \\
4 \mathrm{~A}, \mathrm{C} ; 5 \mathrm{~A}-\mathrm{E}\end{array}$ & $\begin{array}{l}\text { Framework and indicators for long- } \\
\text { term monitoring (including leadership } \\
\text { and support for the Interagency Monitoring } \\
\text { Team) }\end{array}$ & Ongoing & All focal habitats & $\begin{array}{l}\text { Status \& trends, science } \\
\text { foundation, policy/outreach }\end{array}$ & 34 \\
\hline $1 \mathrm{~A}, \mathrm{~B} ; 2 \mathrm{~B}, \mathrm{E}$ & $\begin{array}{l}\text { Time-series analysis of multi- } \\
\text { resolution imagery to quantify } \\
\text { sagebrush defoliation and mortality } \\
\text { in southwestern Wyoming }\end{array}$ & New & Sagebrush & $\begin{array}{l}\text { Status \& trends, science } \\
\text { foundation }\end{array}$ & 35 \\
\hline $\begin{array}{l}1 \mathrm{~A}-\mathrm{B} ; 3 \mathrm{~B}-\mathrm{D} ; 4 \mathrm{C} \\
\quad 5 \mathrm{~B}, \mathrm{C}\end{array}$ & $\begin{array}{l}\text { Remote sensing and vegetation } \\
\text { inventory and monitoring }\end{array}$ & Ongoing & $\begin{array}{l}\text { Sagebrush species, } \\
\text { sagebrush steppe }\end{array}$ & $\begin{array}{l}\text { Status \& trends, science } \\
\text { foundation }\end{array}$ & 37 \\
\hline $1 \mathrm{~A}-\mathrm{B} ; 4 \mathrm{C} ; 5 \mathrm{~B}-\mathrm{D}$ & $\begin{array}{l}\text { Long-term monitoring of surface } \\
\text { water, groundwater, and water } \\
\text { quality }\end{array}$ & Ongoing & Riparian, aquatic & $\begin{array}{l}\text { Status \& trends, science } \\
\text { foundation }\end{array}$ & 38 \\
\hline $1 \mathrm{~A}-\mathrm{B} ; 4 \mathrm{C} ; 5 \mathrm{~B}-\mathrm{D}$ & $\begin{array}{l}\text { Analysis of long-term groundwater } \\
\text { elevation data and geologic } \\
\text { description }\end{array}$ & Ongoing $^{1}$ & Aquatic & $\begin{array}{l}\text { Status \& trends, science } \\
\text { foundation, energy resource } \\
\text { development }\end{array}$ & 40 \\
\hline $1 \mathrm{~A}-\mathrm{B} ; 4 \mathrm{C} ; 5 \mathrm{~B}-\mathrm{D}$ & $\begin{array}{l}\text { Evaluation of groundwater } \\
\text { interaction with small streams in } \\
\text { the western Green River Basin to } \\
\text { enhance understanding of aquatic } \\
\text { communities }\end{array}$ & New & Aquatic & $\begin{array}{l}\text { Status \& trends, science } \\
\text { foundation, energy resource } \\
\text { development }\end{array}$ & 42 \\
\hline
\end{tabular}


Table 2. Summary of U.S. Geological Survey science and technical development projects conducted in Fiscal Year (FY) 2015 for the Wyoming Landscape Conservation Initiative (WLCl). For each project, the WLCl management needs and objectives addressed (directly or indirectly) by the project are listed by alphanumeric codes that correspond to management needs and associated objectives listed in table 1 (for example, $1 \mathrm{~A}$ is Management Need 1, objective A). The summary also includes project status as of September 30, 2015, focal species and (or) habitats addressed by the project, and intended or potential applications of project outcomes (such as products, databases, models, or Web tools). Activity titles and page numbers are hypelinked so that users may go directly to the individual project reports for activities of particular interest.—Continued

\begin{tabular}{|c|c|c|c|c|c|}
\hline $\begin{array}{l}\text { Management } \\
\text { needs/objectives } \\
\text { addressed }\end{array}$ & Project title & $\begin{array}{l}\text { Status at } \\
\text { end of } \\
\text { FY2015 }\end{array}$ & $\begin{array}{l}\text { Focal species and (or) } \\
\text { habitat }\end{array}$ & $\begin{array}{l}\text { Intended and potential } \\
\text { applications of project outcomes }\end{array}$ & Page no. \\
\hline \multicolumn{6}{|c|}{ Effectiveness Monitoring activities } \\
\hline $\begin{array}{l}\text { 1A; } 2 \mathrm{~A}-\mathrm{C}, \mathrm{E}-\mathrm{F} ; 3 \mathrm{~A}-\mathrm{C} \\
\quad 4 \mathrm{~A}-\mathrm{D} ; 5 \mathrm{~A}-\mathrm{E}\end{array}$ & $\begin{array}{l}\text { Applying greenness indices to } \\
\text { evaluate sagebrush in the WLCI } \\
\text { region }\end{array}$ & Ongoing & $\begin{array}{l}\text { Sagebrush species, } \\
\text { sagebrush steppe }\end{array}$ & $\begin{array}{l}\text { Status \& trends, science } \\
\text { foundation, policy/outreach }\end{array}$ & 44 \\
\hline $\begin{array}{l}1 \mathrm{~A} ; 2 \mathrm{~A}-\mathrm{D}, \mathrm{F} ; 3 \mathrm{~A}-\mathrm{C} \\
\quad 4 \mathrm{~A}-\mathrm{D} ; 5 \mathrm{~A}-\mathrm{E}\end{array}$ & $\begin{array}{l}\text { Mapping mixed mountain shrub } \\
\text { communities to support WLCI } \\
\text { conservation planning and } \\
\text { effectiveness monitoring of habitat } \\
\text { treatments }\end{array}$ & Ongoing & $\begin{array}{l}\text { Mountain and curl-leaf } \\
\text { mahogany, serviceberry, } \\
\text { chokecherry, antelope } \\
\text { bitterbrush, mixed } \\
\text { mountain shrubland }\end{array}$ & $\begin{array}{l}\text { Status \& trends, science } \\
\quad \text { foundation, policy/outreach }\end{array}$ & 46 \\
\hline $\begin{array}{l}1 \mathrm{~A} ; 2 \mathrm{~A}-\mathrm{C}, \mathrm{E}-\mathrm{F} ; 3 \mathrm{~A}-\mathrm{C} \\
4 \mathrm{~A}-\mathrm{D} ; 5 \mathrm{~A}-\mathrm{E}\end{array}$ & $\begin{array}{l}\text { Greater sage-grouse use of vegetation } \\
\text { treatments }\end{array}$ & Ongoing $^{2}$ & $\begin{array}{l}\text { Greater sage-grouse, } \\
\text { sagebrush steppe (grouse } \\
\text { brood-rearing/ nesting } \\
\text { habitat) }\end{array}$ & $\begin{array}{l}\text { Status \& trends, science } \\
\quad \text { foundation, policy/outreach }\end{array}$ & \\
\hline $\begin{array}{l}1 \mathrm{~A} ; 2 \mathrm{~A}-\mathrm{B} ; 3 \mathrm{~A}-\mathrm{C} \\
4 \mathrm{~A}-\mathrm{D} ; 5 \mathrm{~A}-\mathrm{E}\end{array}$ & $\begin{array}{l}\text { Occurrence of cheatgrass associated with } \\
\text { habitat projects }\end{array}$ & Ongoing $^{2}$ & $\begin{array}{l}\text { Cheatgrass, sagebrush } \\
\text { steppe }\end{array}$ & $\begin{array}{l}\text { Status \& trends, science } \\
\quad \text { foundation, policy/outreach }\end{array}$ & \\
\hline $\begin{array}{l}1 \mathrm{~A} ; 2 \mathrm{~A}-\mathrm{F} ; 3 \mathrm{~A}-\mathrm{C} \\
\quad 4 \mathrm{~A}-\mathrm{D} ; 5 \mathrm{~A}-\mathrm{E}\end{array}$ & $\begin{array}{l}\text { Landscape assessment and } \\
\text { monitoring of semi-arid woodlands } \\
\text { in the Little Mountain Ecosystem }\end{array}$ & Ongoing & Aspen & $\begin{array}{l}\text { Status \& trends, science } \\
\quad \text { foundation, policy/outreach }\end{array}$ & 47 \\
\hline $\begin{array}{l}1 \mathrm{~A} ; 2 \mathrm{~A}-\mathrm{F} ; 3 \mathrm{~A}-\mathrm{C} \\
4 \mathrm{~A}-\mathrm{D} ; 5 \mathrm{~A}-\mathrm{E}\end{array}$ & $\begin{array}{l}\text { Aspen regeneration associated with } \\
\text { mechanical removal of subalpine fir }\end{array}$ & Ongoing $^{2}$ & Aspen, conifer species & $\begin{array}{l}\text { Status \& trends, science } \\
\quad \text { foundation, policy/outreach }\end{array}$ & \\
\hline $\begin{array}{l}1 \mathrm{~A} ; 2 \mathrm{~A}-\mathrm{F} ; 3 \mathrm{~A}-\mathrm{D} \\
4 \mathrm{~A}-\mathrm{D} ; 5 \mathrm{~A}-\mathrm{E}\end{array}$ & $\begin{array}{l}\text { Herbivory, stand condition, and regeneration } \\
\text { rates of aspen on burned and unburned } \\
\text { plots }\end{array}$ & Ongoing $^{2}$ & Aspen & $\begin{array}{l}\text { Status \& trends, science } \\
\quad \text { foundation, policy/outreach }\end{array}$ & \\
\hline
\end{tabular}


Table 2. Summary of U.S. Geological Survey science and technical development projects conducted in Fiscal Year (FY) 2015 for the Wyoming Landscape Conservation Initiative (WLCI). For each project, the WLCI management needs and objectives addressed (directly or indirectly) by the project are listed by alphanumeric codes that correspond to management needs and associated objectives listed in table 1 (for example, $1 \mathrm{~A}$ is Management Need 1, objective A). The summary also includes project status as of September 30, 2015, focal species and (or) habitats addressed by the project, and intended or potential applications of project outcomes (such as products, databases, models, or Web tools). Activity titles and page numbers are hypelinked so that users may go directly to the individual project reports for activities of particular interest.-Continued

\begin{tabular}{|c|c|c|c|c|c|}
\hline $\begin{array}{l}\text { Management } \\
\text { needs/objectives } \\
\text { addressed }\end{array}$ & Project title & $\begin{array}{l}\text { Status at } \\
\text { end of } \\
\text { FY2015 }\end{array}$ & $\begin{array}{l}\text { Focal species and (or) } \\
\text { habitat }\end{array}$ & $\begin{array}{l}\text { Intended and potential } \\
\text { applications of project outcomes }\end{array}$ & Page no. \\
\hline \multicolumn{6}{|c|}{ Mechanistic Studies of Wildlife } \\
\hline $\begin{array}{l}\text { 1A-B; } 2 \mathrm{~A}-\mathrm{F} ; 3 \mathrm{~A}-\mathrm{C} \\
\quad 4 \mathrm{C} ; 5 \mathrm{~A}-\mathrm{D}\end{array}$ & $\begin{array}{l}\text { Modeling habitat associations and } \\
\text { distribution of pygmy rabbits }\end{array}$ & Ongoing & $\begin{array}{l}\text { Pygmy rabbit, sagebrush } \\
\text { steppe }\end{array}$ & $\begin{array}{l}\text { Status \& trends, science } \\
\text { foundation, energy resource } \\
\text { development }\end{array}$ & 48 \\
\hline $\begin{array}{l}1 \mathrm{~A}-\mathrm{B} ; 2 \mathrm{~A}-\mathrm{F} ; 3 \mathrm{~A}-\mathrm{C} \\
\quad 4 \mathrm{C} ; 5 \mathrm{~A}-\mathrm{D}\end{array}$ & $\begin{array}{l}\text { Modeling greater sage-grouse } \\
\text { population responses to landscape } \\
\text { changes }\end{array}$ & Ongoing & $\begin{array}{l}\text { Greater sage-grouse, } \\
\text { sagebrush steppe, sage- } \\
\text { grouse core areas }\end{array}$ & $\begin{array}{l}\text { Status \& trends, science } \\
\text { foundation, policy/outreach, } \\
\text { energy resource development }\end{array}$ & 49 \\
\hline $\begin{array}{l}1 \mathrm{~A}-\mathrm{B} ; 2 \mathrm{~A}-\mathrm{F} ; 3 \mathrm{~A}-\mathrm{C} \\
\quad 4 \mathrm{C} ; 5 \mathrm{~A}-\mathrm{D}\end{array}$ & $\begin{array}{l}\text { Mechanistic understanding of energy } \\
\text { resource development effects on } \\
\text { songbirds }\end{array}$ & Ongoing & $\begin{array}{l}\text { Brewer's sparrow, sagebrush } \\
\text { sparrow, sage thrasher, } \\
\text { sagebrush steppe }\end{array}$ & $\begin{array}{l}\text { Status \& trends, policy/outreach, } \\
\text { energy resource development }\end{array}$ & 50 \\
\hline $\begin{array}{l}1 \mathrm{~A}-\mathrm{B} ; 2 \mathrm{~A}-\mathrm{F} ; 3 \mathrm{~A}-\mathrm{C} \\
\quad 4 \mathrm{C} ; 5 \mathrm{~A}-\mathrm{D}\end{array}$ & $\begin{array}{l}\text { Identifying threshold levels of } \\
\text { development that impede Wyoming } \\
\text { ungulate migrations }\end{array}$ & Ongoing & $\begin{array}{l}\text { Mule deer, mixed mountain } \\
\text { shrubland (crucial winter } \\
\text { habitat) }\end{array}$ & $\begin{array}{l}\text { Status \& trends, policy/outreach, } \\
\text { energy resource development }\end{array}$ & 51 \\
\hline $\begin{array}{l}\text { 1A-B; } 2 \mathrm{~A}-\mathrm{F} ; 3 \mathrm{~A}-\mathrm{C} ; \\
\quad 4 \mathrm{C} ; 5 \mathrm{~A}-\mathrm{D}\end{array}$ & $\begin{array}{l}\text { Influence of energy resource } \\
\text { development on native fish } \\
\text { communities }\end{array}$ & Ongoing & $\begin{array}{l}\text { Mountain sucker, mottled } \\
\text { sculpin, cutthroat trout } \\
\text { and all other native fish } \\
\text { species; aquatic and } \\
\text { riparian habitats }\end{array}$ & $\begin{array}{l}\text { Science foundation, } \\
\text { policy/outreach, energy } \\
\text { resource development }\end{array}$ & 52 \\
\hline
\end{tabular}


Table 2. Summary of U.S. Geological Survey science and technical development projects conducted in Fiscal Year (FY) 2015 for the Wyoming Landscape Conservation Initiative (WLCl). For each project, the $\mathrm{WLCl}$ management needs and objectives addressed (directly or indirectly) by the project are listed by alphanumeric codes that correspond to management needs and associated objectives listed in table 1 (for example, $1 \mathrm{~A}$ is Management Need 1, objective A). The summary also includes project status as of September 30, 2015, focal species and (or) habitats addressed by the project, and intended or potential applications of project outcomes (such as products, databases, models, or Web tools). Activity titles and page numbers are hypelinked so that users may go directly to the individual project reports for activities of particular interest. —Continued

\begin{tabular}{|c|c|c|c|c|c|}
\hline $\begin{array}{c}\text { Management } \\
\text { needs/objectives } \\
\text { addressed }\end{array}$ & Project title & $\begin{array}{l}\text { Status at } \\
\text { end of } \\
\text { FY2015 }\end{array}$ & $\begin{array}{l}\text { Focal species and (or) } \\
\text { habitat }\end{array}$ & $\begin{array}{l}\text { Intended and potential } \\
\text { applications of project outcomes }\end{array}$ & Page no. \\
\hline \multicolumn{6}{|c|}{ Data and Information Management activities } \\
\hline $5 \mathrm{D} ; 6 \mathrm{~A}-\mathrm{D}$ & $\begin{array}{l}\text { Data management framework and } \\
\text { catalog (including development of a } \\
\text { Web-based reference tool for partner } \\
\text { monitoring activities and a data access tool } \\
\text { to USGS remote sensing and other } \\
\text { products) }\end{array}$ & Ongoing & $\mathrm{N} / \mathrm{A}$ & $\begin{array}{l}\text { Science foundation, } \\
\text { policy/outreach }\end{array}$ & 53 \\
\hline $6 \mathrm{~B}-\mathrm{D}$ & $\begin{array}{l}\text { Outreach and graphic products: Web } \\
\text { application development for data } \\
\text { visualization (now combines } \\
\text { development of Web applications and } \\
\text { graphics and other outreach products) }\end{array}$ & Ongoing & N/A & $\begin{array}{l}\text { Science foundation, } \\
\text { policy/outreach }\end{array}$ & 54 \\
\hline
\end{tabular}

\footnotetext{
${ }^{1}$ New project phase or new focus and title.

${ }^{2}$ Activities that entail ongoing work, including monitoring (for example, some habitat treatment projects do not require annual data collection), analysis, development of data-processing scripts, and (or) other product development, but which did not have tangible outcomes or products in fiscal year (FY) 2015, are not included in this report. See prior annual reports for more information on these projects.

${ }^{3}$ Project completed in FY2015, but final products not expected until FY2016.
} 


\section{Using a Three-Tiered Approach for Building a Solid Foundation for Management and Science}

The USGS science strategy for the WLCI is based on a three-tiered approach for organizing and guiding USGS WLCI science and related activities (fig. 2). The "ground-level," or "foundation," tier of our science strategy is a large-scale, ongoing Baseline Synthesis. Science activities of this tier entail acquiring, compiling, standardizing, and integrating existing and new data for ascertaining baseline resource conditions, conducting landscape-scale assessments, and projecting potential trajectories of habitat conditions and wildlife populations under future scenarios of energy resource development and other changes. The WLCI management needs addressed by these activities are primarily 1 and 2, although 3-6 are addressed and integrated with this work as well (tables 1 and 2).

The Baseline Synthesis provides the foundation for our second tier, Targeted Monitoring and Research. That is, once we know something about the historical and present, or baseline, resource conditions, we can begin to monitor and track trends in resource conditions, compare future conditions to the baseline, and test hypotheses about what drives those trends. This

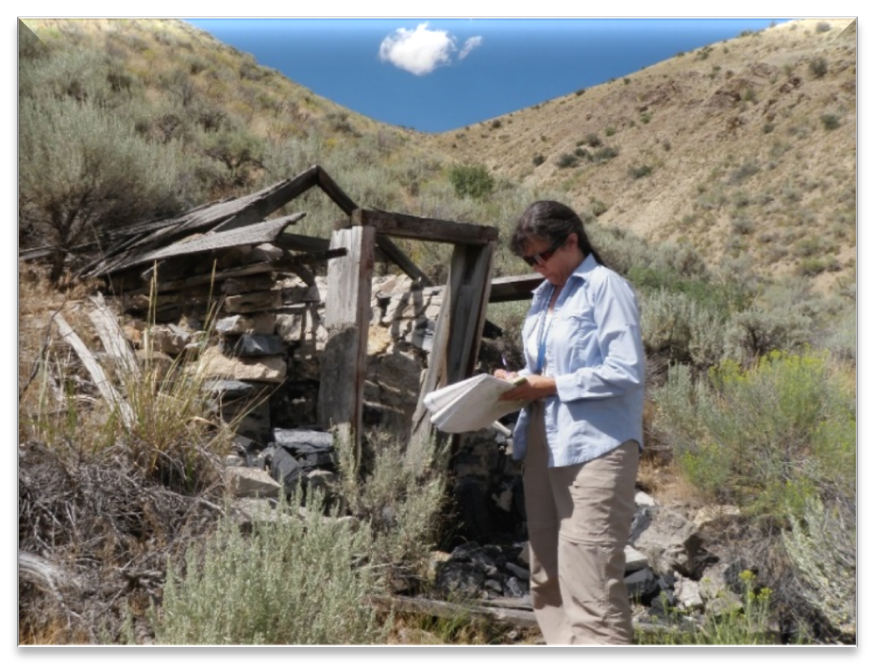

Anna Wilson taking notes and location of an abandoned mine near Cokeville, Wyoming. Photograph by Bill Heran, U.S Geological Survey. tier, therefore, comprises a suite of projects that focus on (1) long-term monitoring of WLCI natural resources, (2) effectiveness monitoring of on-the-ground WLCI habitat enhancement and restoration projects, and (3) research designed to elucidate the ways in which energy resource development, climate change, and other change agents affect wildlife and their habitats.

Our long-term monitoring activities include designing, guiding, and (or) conducting long-term monitoring to ascertain the trajectories of habitat change, especially at the landscape scale. This work also includes leading the IAMT and developing the IAMD. The primary management need met by these activities is 5, although they also address needs 1-4 and are highly integrated with need 6 (tables 1 and 2). Effectiveness monitoring activities are designed to evaluate the efficacy of on-the-ground habitat management projects conducted by WLCI partners. The primary management need addressed by these activities is 4, but they also help to address needs 1-3 and 5 and again are highly integrated with 6 (tables 1 and 2). All of our mechanistic studies of wildlife have entailed sequential phases of work to reveal the actual mechanisms that drive wildlife and habitat responses to changes. The management needs addressed by this work are primarily 2 and 3, although 1, 4, and 5 are addressed as well, and results are integrated with need 6 (tables 1 and 2).

All three focal areas of the Targeted Monitoring and Research work also include developing and testing the efficacy of innovative methods for landscape-scale monitoring, particularly fusions of data collected from the field and ground-based instruments with satellite imagery and other remotely sensed data. In turn, the data and other information derived from these studies are integrated into the Baseline Synthesis to build the overall science foundation for the WLCI region and other large-scale conservation initiatives. 


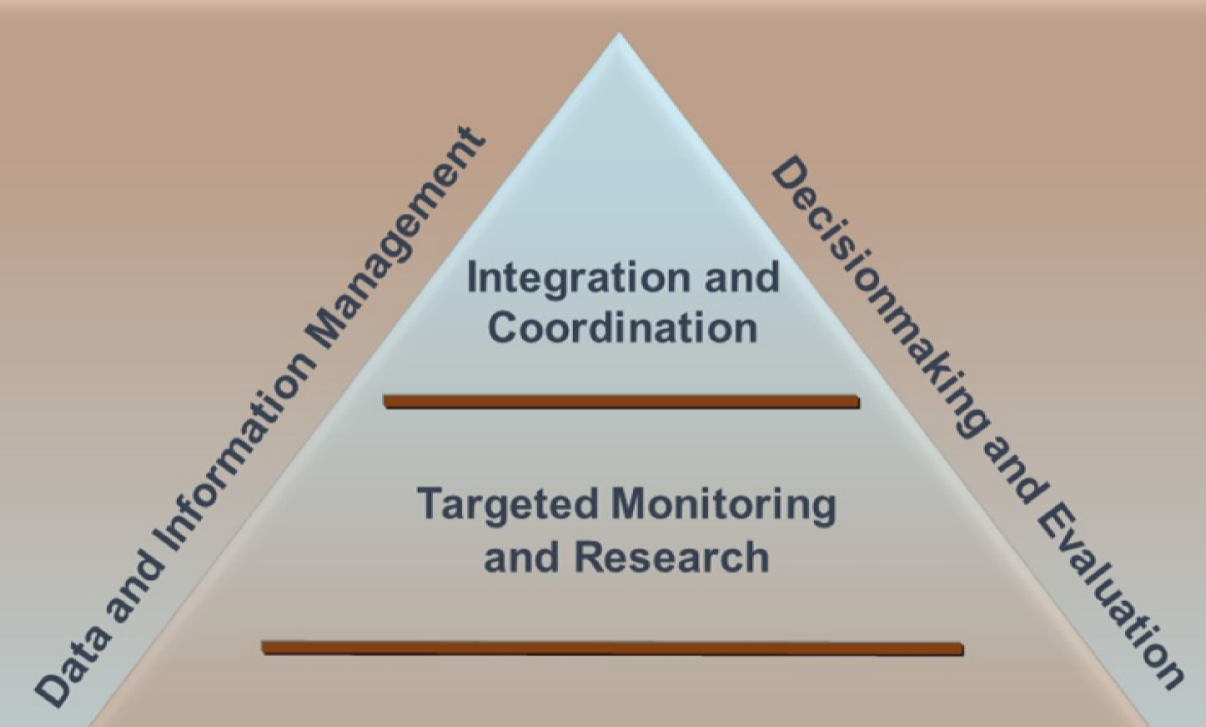

Baseline Synthesis

WLCI Partner Management Needs and Information Gaps

Figure 2. The U.S. Geological Survey's framework for guiding assessment, monitoring, and research of ecosystem components. The Management Needs identified by the Wyoming Landscape Conservation Initiative (WLCl) partners form the foundation of the major U.S. Geological Survey science activities for the WLCl: (1) Baseline Synthesis, (2) Targeted Monitoring and Research, (3) Integration and Coordination, and (4) Data and Information Management, which inform and support (5) Decisionmaking and Evaluation. The first three of these activities represent successive stages that build on information gained from earlier stages, and at all stages Data and Information Management ensures access to information and data for use in Decisionmaking and Evaluation. This approach is iterative and allows for stages to overlap.

The top tier of the USGS science strategy, Integration and Coordination, is largely handled by the USGS liaison to the WLCI Coordination Team by working closely with WLCI partners and leadership teams. He ensures that WLCI partners receive or have access to the growing body of knowledge, including data and completed products, being developed by the Science Team to help inform adaptive management strategies, best management practices, and prioritization of on-the-ground habitat projects developed by WLCI partners. He also facilitates the integration of new knowledge and technologies with ongoing and future science and habitat conservation projects. Not only does our liaison assist with USGS product dissemination, he assists WLCI partners, collaborators, and stakeholders with interpretation and use of USGS products. 


\section{A Snapshot of 2008-2015 Milestones Accomplished by the USGS to Help Address WLCI Management Needs}

- We have acquired and synthesized a significant body of baseline data and used these data for developing a comprehensive Integrated Assessment of landscape condition across the WLCI region, and WLCI partners have had opportunities to attend USGS presentations on how they may use the assessment for decisionmaking.

- We continue to assess historical/current and (or) potential future status and trends of priority habitats/species, agricultural interests, and energy/minerals across the WLCI region.

- We have identified many key drivers of landscape change and continue to develop models for projecting potential future changes arising from these drivers.

- We have identified the distribution and condition of all 152 Wyoming Species of Greatest Conservation need.

- We have established a framework, indicators, and an integrated interagency monitoring database for long-term monitoring of ecosystem conditions across the $\mathrm{WLCl}$ region.

- We are monitoring the effectiveness of on-the-ground habitat enhancement and restoration projects implemented by WLCI partners to ascertain whether they achieve intended objectives at landscape scales.

- We have elucidated many of the mechanisms underlying changes in the status and trends of WLCI focal habitats and species that result from energy resource development.

- We have developed and continue to enhance Web-based applications, including the WLCI Web site, for making accessible the arrays of WLCI data, maps, models, publications, and other products.

- We continue to inform and provide support to WLCI partner conservation planners and decisionmakers. To a great extent, this has taken place through the four WLCI biannual science workshops hosted by the USGS, including a first joint WLCI-Wyoming Chapter of The Wildlife Society conference in 2015.

The USGS provides ongoing technological support for all three tiers of USGS science work. This includes developing, maintaining, and enhancing the infrastructure and software applications used to compile, archive, search, serve, and (or) display data and other products stored in the USGS ScienceBase catalog and (or) on WLCI Website. Our technologists also help to ensure that interactive assessments and map viewer tools are available to policymakers and managers at all levels to help inform and support their decisionmaking and evaluations of WLCI approaches and programs. With each 
additional year of the overall WLCI effort, technologies and protocols are advanced to increase their efficiency and accuracy, and the growing body of data and information is updated and better integrated for use in WLCI landscape-scale planning and management.

\section{A Guide to Using This Report}

The USGS has produced a comprehensive annual report to highlight its WLCI science accomplishments for each Federal fiscal year (FY: October 1 through September 30) since inception of the WLCI (Bowen, Aldridge, Anderson, Assal, and others, 2009, 2010, 2011, 2013, 2014a, 2014b, 2015). Past reports may be accessed at the URLs listed in the box below. This is the eighth annual report that highlights USGS science and technical assistance activities conducted in FY2015. The FY2015 activities, as they relate to the WLCI management needs (table 1) and other WLCI activities, are summarized in table 2 .

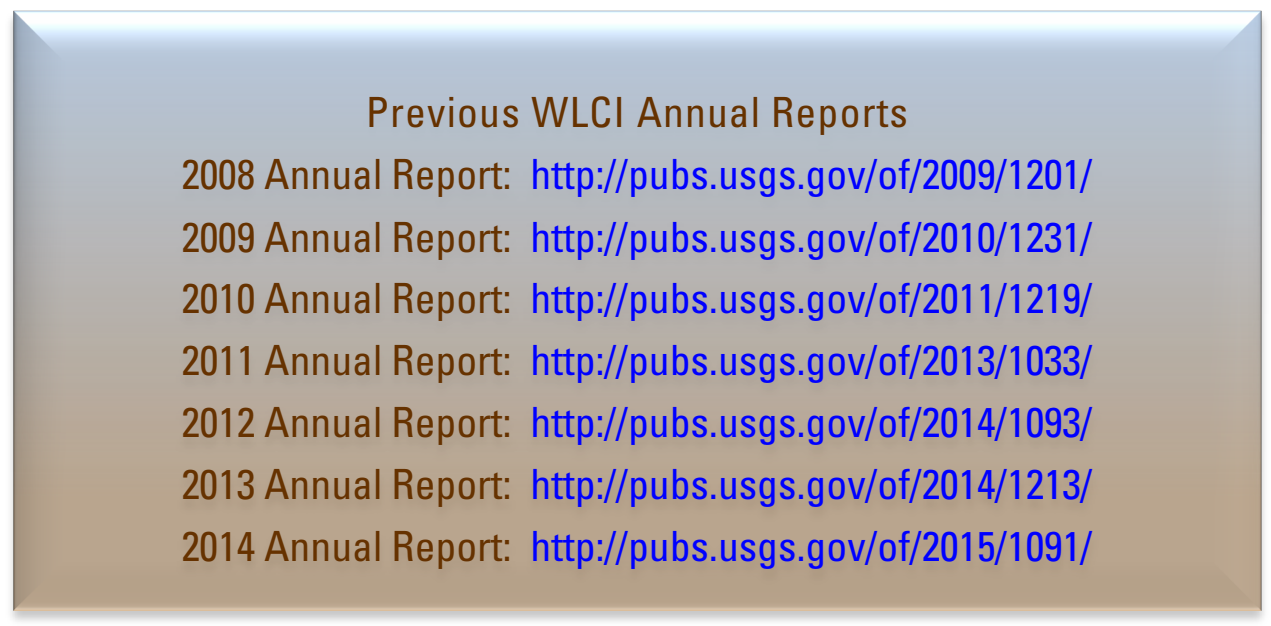

To help WLCI partners focus on accomplishments, products, take-home messages, and applications of USGS work, this report provides two major components: (1) Highlights of FY2015 USGS WLCI Science Accomplishments, and (2) individual one- to two-page reports for each project. Individual reports for new projects include more in-depth information; this type of in-depth information for ongoing and completed projects was provided in earlier annual reports. Readers seeking just an overview of USGS activities and major accomplishments will benefit from reading the highlights on pages 15-26. Readers seeking more detailed information on individual projects will benefit from reading the individual reports of interest that follow the highlights section.

The individual reports are snapshots of project needs and objectives, general approaches, takehome messages of findings, and major products. They also may indicate organizations that are using or may use project products. We use quick-reference icons (see definitions below) to the left of each project report title to indicate intended and potential applications of project outcomes. Readers seeking more comprehensive project information, background and methods, detailed results, and a cumulative list of products and outcomes may visit the WLCI Web site at http://www.wlci.gov/ and search on activities of interest. Finally, where applicable, we have included URLs in the individual reports for directly accessing USGS and outside products published in FY2015. At the end of the report is a list of references cited. 
Descriptions of the work planned for FY2016 are available on the WLCI Web site under each ongoing project. In addition to published products, significant USGS Science Team accomplishments continue to be presented at WLCI meetings and science workshops, which are generally posted on the WLCI Web site. The contacts for USGS WLCI activity, including Coordination and Integration and Evaluations of USGS science continue to be Patrick Anderson (970-226-9488; andersonpj@usgs.gov) and Zachary Bowen (970-226-9218; bowenz@usgs.gov).

Icons Used to Identify Existing and Potential Applications of Individual USGS WLCI Science Projects

Project outcome applications include building or contributing to the WLCI Science Foundation.

Project outcome applications include addressing Policies (such as the National Environmental Policy Act), Conservation Planning, Education and (or) Outreach.

Project outcome applications include assessing and monitoring Status and Trends.

Project outcome applications include evaluating effects of Energy resource development. 


\section{Highlights of FY2015 USGS WLCI Science Accomplishments}

The 2015 Joint Science Conference: A Collaboration between the Wyoming Chapter of The Wildlife Society and the Wyoming Landscape Conservation Initiative

The fourth WLCI science conference, sponsored by the USGS, Bureau of Land Management (BLM), and National Park Service, took place December 1-3, 2015, in Lander, Wyoming. Although December is part of Federal FY2016, we nonetheless felt that it was important to report workshop highlights in this annual report because it represented work completed up through FY2015. This was the fourth WLCI science conference held since the inception of the WLCI, but it was the first time that USGS coordinated it with the Wyoming chapter of The Wildlife Society. It was anticipated that this joint-conference strategy would not only grow the number of people brought together, but also stimulate increased idea sharing and collaboration, encourage new and innovative projects, and provide a greater breadth of feedback for both existing projects and potential future projects.

The joint conference was a great success, with approximately 260 participants, including restoration practitioners, resource specialists, research scientists, managers and planners, students, and policy and legislative staff. Local newspaper, radio, and television representatives were also in attendance to cover this important event. Of the conference participants, 41 were USGS professionals representing 13 USGS science centers, field offices, and university Cooperative Research Units. Fifteen of 62 oral presentations and 3 of 21 poster presentations provided by USGS scientists and associates were specific to WLCI projects (table 3). Major themes of USGS WLCI presentations included using new technologies to innovate more efficient, effective research protocols for mapping, modeling, and monitoring resources; researching effects of development and other changes on focal wildlife species and habitats; and modeling sage-grouse population trends and viability, habitat use, and mitigating effects of land-use changes. Indeed, a special session focused on the effectiveness of Wyoming's SageGrouse Executive Order. Other conference activities included workshops on developing leadership skills, career opportunities and collaborating with industry and other non-governmental agencies, communicating with and engaging non-scientific audiences, and an instruction course on the R software program.

Overall, participants were engaged, as indicated by many discussions and an emphasis on more collaboration during breaks and the poster session. Numerous USGS participants reported making new connections, both within the USGS and with WLCI partners, and look forward to promises of future collaborations. Although the sage-grouse continues to be an important focal point of interest in the WLCI region and Wyoming overall, there was a general consensus that future science efforts should focus more on the sagebrush ecosystem as a whole, including the full suite of sagebrush obligate species, rather than focusing on just a few species that live within the sagebrush ecosystem. 
Table 3. Presentations and posters given at the December 2015 Wyoming Landscape Conservation Initiative (WLCI) Science Workshop by U.S. Geological Survey scientists involved with WLCl projects (see workshop program at https://www.wlci.gov/sites/default/files/events/2015\%20Conference\%20Program2.pdf). Presentations are grouped by workshop number and session title as they were in the workshop program. U.S Geological Survey WLCl project leads and co-leads are underlined, and associated WLCI project titles are hyperlinked so that readers may go directly to the project report herein for more information and principal investigator contact information.

\begin{tabular}{|c|c|c|}
\hline Presentation title & Principal investigators & Associated WLCI project title(s) \\
\hline \multicolumn{3}{|c|}{ Session 1: New methods, models, and more } \\
\hline $\begin{array}{l}\text { Groundwater and surface-water } \\
\text { interaction in the upper Green } \\
\text { River basin }\end{array}$ & $\begin{array}{l}\text { Cheryl A. Eddy-Miller, } \\
\text { Jerrod D. Wheeler, Ruth } \\
\text { M. Law }\end{array}$ & $\begin{array}{l}\text { Long-term monitoring of surface water, } \\
\text { groundwater, and water quality }\end{array}$ \\
\hline $\begin{array}{l}\text { Spatial and temporal trends of } \\
\text { drought effects on aspen forest in } \\
\text { southwestern Wyoming }\end{array}$ & $\frac{\text { Timothy J. Assal, Patrick J. }}{\text { Anderson, Jason Sibold }}$ & $\begin{array}{l}\text { Landscape assessment and monitoring of } \\
\text { semi-arid woodlands in the Little } \\
\text { Mountain Ecosystem }\end{array}$ \\
\hline $\begin{array}{l}\text { Mountain shrub mapping using } \\
\text { remotely sensed data, statistical } \\
\text { models and ground-truthing }\end{array}$ & $\begin{array}{l}\text { Geneva Chong, Catherine } \\
\text { Jarnevich, Marie } \\
\text { Dematitis, Timothy Assal, } \\
\text { Patrick Anderson }\end{array}$ & $\begin{array}{l}\text { Mapping mixed mountain shrub } \\
\text { communities to support WLCI } \\
\text { conservation planning and effectiveness } \\
\text { monitoring of habitat treatments }\end{array}$ \\
\hline
\end{tabular}

Session 3: Costs of creature comforts: Wildlife versus human development

Mechanisms underlying effects of energy resource development on wildlife: An update on WLCI songbird research

Simulation assessment of future oil and gas development scenarios and impacts to pygmy rabbit habitat

On gas fields and pygmy rabbits: Factors explaining rabbit presence and abundance

The effects of oil and gas development for aquatic habitats

Does oil and natural gas development and hydrology interact to affect fish population dynamics?
Anna D. Chalfoun, Matthew G. Hethcoat, Tracey N. Johnson, Lindsey E. Sanders

Steven L. Garman, Stephen S. Germaine

Steve Germaine, Sarah Carter, Drew Ignizio

Annika Walters, Carlin Girard

Richard Walker, Carlin Girard, Annika Walters
Mechanistic understanding of energy resource development effects on songbirds

Modeling habit associations and distribution of Pygmy rabbit

Modeling habit associations and distribution of Pygmy rabbit

Influence of energy resource development on native fish communities

Influence of energy resource development on native fish communities

Session 6: Dynamics of sage-grouse populations and sagebrush habitats

Multi-scale statewide Wyoming greater sage-grouse population viability analysis

A Bayesian state-space model to estimate sage-grouse trends: Impacts of oil and gas development
David R. Edmunds, Michael S. O'Donnell, Adrian P. Monroe, Cameron L. Aldridge

Adam W. Green, Cameron L. Aldridge, Michael S. O’Donnell
Modeling greater sage-grouse populations responses to landscape changes

Modeling greater sage-grouse populations responses to landscape changes 
Table 3. Presentations and posters given at the December 2015 Wyoming Landscape Conservation Initiative (WLCI) Science Workshop by U.S. Geological Survey scientists involved with WLCl projects (see workshop program at https://www.wlci.gov/sites/default/files/events/2015\%20Conference\%20Program2.pdf). Presentations are grouped by workshop number and session title as they were in the workshop program. U.S Geological Survey WLCl project leads and co-leads are underlined, and associated WLCI project titles are hyperlinked so that readers may go directly to the project report herein for more information and principal investigator contact information.-Continued

\begin{tabular}{|c|c|c|}
\hline Presentation title & Principal investigators & Associated WLCI project title(s) \\
\hline $\begin{array}{l}\text { Mitigation by design in Wyoming: } \\
\text { Making the connection between } \\
\text { wildlife distribution, habitat, } \\
\text { restoration, and mitigation }\end{array}$ & $\begin{array}{l}\text { Daniel Manier, Adam } \\
\text { Green, Adrian Monroe, } \\
\text { Cameron Aldridge, } \\
\text { Michael O’Donnell }\end{array}$ & $\begin{array}{l}\text { Modeling greater sage-grouse population } \\
\text { responses to landscape changes }\end{array}$ \\
\hline $\begin{array}{l}\text { Greater sage-grouse response to } \\
\text { grazing timing and intensity in } \\
\text { Wyoming }\end{array}$ & $\begin{array}{l}\text { Adrian P. Monroe, Cameron } \\
\text { L. Aldridge, Timothy J. } \\
\text { Assal, Kari E. Veblen, } \\
\text { David A. Pyke, Michael } \\
\text { L. Casazza }\end{array}$ & $\begin{array}{l}\text { Modeling greater sage-grouse population } \\
\text { responses to landscape changes }\end{array}$ \\
\hline $\begin{array}{l}\text { Long term sagebrush habitat } \\
\text { monitoring across WLCI, what is } \\
\text { changing and what does it mean? }\end{array}$ & $\begin{array}{c}\text { Collin Homer, Debbie } \\
\text { Meyer, George Xian }\end{array}$ & $\begin{array}{l}\text { Remote sensing and vegetation inventory } \\
\text { and monitoring }\end{array}$ \\
\hline \multicolumn{3}{|c|}{ Session 7: Ungulate migration, migration habitat, and the green wave } \\
\hline $\begin{array}{l}\text { Evaluating the influence of } \\
\text { development on mule deer } \\
\text { migrations }\end{array}$ & $\begin{array}{l}\text { Teal B. Wyckoff, Matthew } \\
\text { J. Kauffman, Shannon E. } \\
\text { Albeke, Hall Sawyer, } \\
\text { Steven L. Garman }\end{array}$ & $\begin{array}{l}\text { Identifying threshold levels of } \\
\text { development that impede Wyoming } \\
\text { mule deer migrations }\end{array}$ \\
\hline $\begin{array}{l}\text { Does drought affect the ability of } \\
\text { migratory mule deer to surf the } \\
\text { green wave? }\end{array}$ & $\begin{array}{l}\text { Ellen Aikens, Kevin } \\
\text { Monteith, Jerod Merkle, } \\
\text { Geneva W. Chong, } \\
\text { Samantha Dwinnell, } \\
\text { Matthew J. Kauffman }\end{array}$ & $\begin{array}{l}\text { Applying greenness indices to evaluate } \\
\text { sagebrush in the WLCI region } \\
\text { Identifying threshold levels of } \\
\text { development that impede Wyoming } \\
\text { mule deer migrations }\end{array}$ \\
\hline $\begin{array}{l}\text { Straight from the mule deer's mouth: } \\
\text { Using both satellite data and deer } \\
\text { migration locations to explore } \\
\text { temporal and spatial trends in } \\
\text { landscape vegetation productivity }\end{array}$ & $\begin{array}{l}\text { Geneva Chong, Ellen } \\
\text { Aikens, Marian Talbert, } \\
\text { Jeffrey Morisette, } \\
\text { Matthew J. Kauffman, } \\
\text { Timothy J.Assal, Brian } \\
\text { Miller }\end{array}$ & $\begin{array}{l}\text { Applying greenness indices to evaluate } \\
\text { sagebrush in the WLCI region } \\
\text { Identifying threshold levels of } \\
\text { development that impede Wyoming } \\
\text { mule deer migrations }\end{array}$ \\
\hline
\end{tabular}

Special Session: Effectiveness of Wyoming's Sage-Grouse Executive Order

Predicting habitat use for greater sage-grouse using a spatially explicit demographic approach in Wyoming
Julie A. Heinrichs, Cameron L. Aldridge, Micheal S. O’Donnell, Nathan H. Schumaker
Modeling greater sage-grouse population responses to landscape changes 
Table 3. Presentations and posters given at the December 2015 Wyoming Landscape Conservation Initiative (WLCI) Science Workshop by U.S. Geological Survey scientists involved with WLCI projects (see workshop program at https://www.wlci.gov/sites/default/files/events/2015\%20Conference\%20Program2.pdf). Presentations are grouped by workshop number and session title as they were in the workshop program. U.S Geological Survey WLCl project leads and co-leads are underlined, and associated WLCl project titles are hyperlinked so that readers may go directly to the project report herein for more information and principal investigator contact information.-Continued

\begin{tabular}{|c|c|c|}
\hline Presentation title & Principal investigators & Associated WLCI project title(s) \\
\hline \multicolumn{3}{|c|}{ Posters } \\
\hline $\begin{array}{l}\text { Groundwater and geohydrology of } \\
\text { the lower Tertiary aquifer system, } \\
\text { northern Green River basin, } \\
\text { Wyoming }\end{array}$ & $\begin{array}{l}\text { Cheryl A. Eddy-Miller, } \\
\text { Timothy T. Bartos, Laura } \\
\text { L. Hallberg }\end{array}$ & $\begin{array}{l}\text { Analysis of long-term groundwater } \\
\text { elevation data and geologic description }\end{array}$ \\
\hline $\begin{array}{l}\text { Mechanisms underlying increased } \\
\text { songbird nest predation rates with } \\
\text { natural gas development }\end{array}$ & $\begin{array}{l}\text { Lindsey Sanders, Anna } \\
\text { Chalfoun }\end{array}$ & $\begin{array}{l}\text { Mechanistic understanding of energy } \\
\text { resource development effects on } \\
\text { songbirds }\end{array}$ \\
\hline $\begin{array}{l}\text { Inorganic mineral resources in the } \\
\text { Wyoming Landscape Conservation } \\
\text { Initiative study area }\end{array}$ & $\underline{\text { Anna B. Wilson }}$ & Mineral resources \\
\hline \multirow[t]{2}{*}{$\begin{array}{l}\text { National biogeographic efforts for } \\
\text { regional science and management }\end{array}$} & $\frac{\text { Daniel Wieferich, R. Sky }}{\text { Bristoll, Alexa McKerrow }}$ & Data management framework and catalog \\
\hline & & $\begin{array}{l}\text { Web application development for data } \\
\text { Outreach and graphic products } \\
\text { visualization }\end{array}$ \\
\hline
\end{tabular}

\section{Highlights of USGS WLCI Science Team Accomplishments in FY2015}

In FY2015, the Science Team continued or initiated work on 24 WLCI projects in 5 major areas of scientific research and technological development: 4 Baseline Synthesis projects; 6 Long-Term Monitoring projects, including two new ones; 7 Effectiveness Monitoring projects; 5 Mechanistic Studies of Wildlife; and 2 Data and Information Management projects. Here, we summarize highlights of the FY2015 accomplishments within each major area of work and specify the WLCI management needs that they address.

Highlights of FY2015 Baseline Synthesis Accomplishments: Supporting WLCI Planning and Decisionmaking with Data Compilation and Landscape-Scale Assessment Tools

Our Baseline Synthesis projects directly address WLCI management needs to identify key drivers of change (particularly energy and minerals development, invasive species, and climate change), the condition/distribution of key wildlife species and habitats, and species' habitat requirements. They also support several objectives listed under the management needs to evaluate effectiveness of restoration, reclamation, and mitigation activities and to develop an integrated inventory and monitoring strategy (tables 1 and 2). Most of our Baseline Synthesis work has been accomplished through direct USGS funding for the WLCI; however, USGS has capitalized on 
opportunities to leverage other USGS projects to benefit the WLCI mission and add value to the overall science foundation of baseline information, data, and products.

An important FY2015 accomplishment was the completion of our project to develop an index of important agricultural lands in the WLCI region. An associated final report was drafted to detail the methods, results, and implications of this work; the final publication is expected in FY2016. The index improves upon existing measures of agricultural productivity as well as the historical, ecological, and socioeconomic dimensions of agriculture in the WLCI region. Once uploaded to the WLCI Integrated Assessment (IA), the index should prove useful to regional planners and managers of on-the-ground activities when they need to consider the values associated with agricultural lands.

Highlights of our Land-Cover/Land-Use Modeling study included simulations of nine alternative build-out scenarios for oil and gas development. A fact sheet was published in FY2015 to illustrate how these simulations are conducted and provide an applied example for the Atlantic Rim (Garman, 2015; see http://pubs.usgs.gov/wlci/fs/7/). Using published species' responses to energy resource development, we are using the energy development scenarios for assessing effects of these nine energy resource development scenarios on WLCI focal species. Starting with the pygmy rabbit, we are estimating the amount of habitat that has at least a 50 percent probability of occupancy under each scenario. We also prepared a manuscript that proposes a spatial framework for assessing potential effects of oil and gas development on physical and wildlife resources in southwestern Wyoming. Lastly, a "regionalization" exercise was conducted for the WLCI study area, which involved using spatial landscape patterns to transform many geographic units into 14 generalized landscape types with similar land-use/land-cover characteristics. These types may be used to identify similar landscape types for a variety of purposes, including monitoring or conservation projects. Current and future delineations also may be compared to identify changes on the landscape.

In FY2015, Comprehensive Assessment accomplishments included assisting the WLCI Coordination Team with updating the WLCI Conservation Action Plan, the spatial database of WLCI habitat treatments, and conservation project information on the WLCI Web site. As in prior years, we provided materials to support evaluations and rankings of WLCI conservation projects proposed for 2016. As in prior years, this project includes developing and publishing the USGS WLCI annual reports and writing a portion of the BLM WLCI annual reports. In FY2015, the Comprehensive Assessment also supported a new project to assess changes in the productivity of sagebrush patches identified as having undergone defoliation or mortality (see highlights of the Long-Term Monitoring section).

A major component of the Comprehensive Assessment continues to be the WLCI IA tool on the WLCI Web site. New data elements were prepared for the IA in FY2015 and will be incorporated in FY2016. These include not only the new important agricultural lands index, but also an update of the WLCI priority areas. In addition, we are using the IA to assess the spatial factors associated with energy development (well pads) and topography (such as aspect and slope) as they relate to crucial mule deer winter habitat, both to inform WLCI partners about trends associated with crucial mule deer winter habitat and to showcase how the IA may be used for addressing management questions.

An important FY2015 accomplishment in our Mineral Resources project was publication of a USGS uranium resource survey for the WLCI region (Wilson, 2015; see http://dx.doi.org/10.3133/ofr20141123). The USGS online inventory of mineral resources data, geodatabases, and documentation was updated as well (see http://mrdata.usgs.gov/mrds/). These products should prove useful to LPDTs and regional planners for better understanding the distribution and associated characteristics of uranium resources and recovery sites in southwestern Wyoming. 
Collectively, the data, models, assessments, and published products generated through our Baseline Synthesis work are providing WLCI partners and LPDTs with crucial information about historical and current resource distributions and conditions across the entire WLCI landscape. Analyzed baseline data, the Integrated Assessment, and Land-Cover/Land-Use models projecting future energydevelopment scenarios and effects on wildlife present LPDTs and regional planners with powerful tools to help guide their conservation strategies and activities at a range of spatial scales.

Highlights of FY2015 Targeted Monitoring and Research Accomplishments: Assessing Status and Trends of Terrestrial and Aquatic Systems, Effectiveness of On-the-Ground Habitat Projects, and Wildlife Responses to Energy Resource Development

\section{Long-Term Monitoring}

Our Long-Term Monitoring projects directly address the WLCI management need to develop an integrated inventory and monitoring strategy. They also indirectly address management needs to identify key drivers of change, the condition and distribution of wildlife and their habitats, and wildlife habitat requirements. Some of these activities involve using emerging technologies and developing and testing innovative methods for maximizing the efficiency and efficacy of monitoring efforts. Additionally, these activities are integral to addressing the need for developing a data clearinghouse (tables 1 and 2).

In FY2014, WLCI partners noted large areas of sagebrush defoliation or mortality in southwestern Wyoming. Hypotheses about what is driving these events vary from flooding and drought to temperature extremes and effects of disease or pests, and in FY2015, we piloted a new project to investigate this phenomenon. Expanding on our current use of remote sensing technology for landscapescale monitoring, we will use time-series satellite imagery to develop indices of vegetation productivity during the growing seasons of 2000-15. The indices will serve as a basis for monitoring, assessing, and comparing productivity trends in healthy and defoliated/dead stands of sagebrush. We also collected coordinates and photographs of defoliation/mortality sites and added them to existing site data collected by agency personnel in southwestern Wyoming. Finally, we collected vegetation community structure data and samples of sagebrush stems along transects in patches of defoliated/dead and healthy/live sagebrush. The field data will help us to interpret changes detected from remotely sensed data.

We also continue to use remote sensing for inventorying and monitoring vegetation in our longterm QuickBird study sites (two scenes in the WLCI landscape captured by the Quickbird satellite). In FY2015, a 25-year trend analysis of sagebrush ecosystem components, including sagebrush, herbaceous, and bare ground cover, was completed and we published a related manuscript on forecasting changes (up to 2050) in these components and sage-grouse habitat (Homer and others, 2015). The trend analysis helped us to identify drought as a driver of increased bare ground area over that 25-year period.

In FY2015, our collaborations with WLCI partners continued for building the IAMD and integration and analysis strategies for WLCI monitoring data. We also continued to provide technical input and expertise for WLCI research study designs and analyses, LPDT projects, post-disturbance vegetation and wildlife dynamics, invasive plant species, and shrubland conservation and management. Our assistance included working with the sagebrush defoliation/mortality study to analyze 2015 data and plan the work for FY2016, compiling USGS and WLCI partner data for a regional assessment of range conditions, and comparing trends on developed and treated lands to identify factors associated with changes in vegetation dynamics. An important FY2015 product of our invasives research was a 
publication on the distributions of nine invasive plant species in southwestern Wyoming (Manier and others, in review), which will help planners and managers target areas for management actions.

Our aquatic Long-term

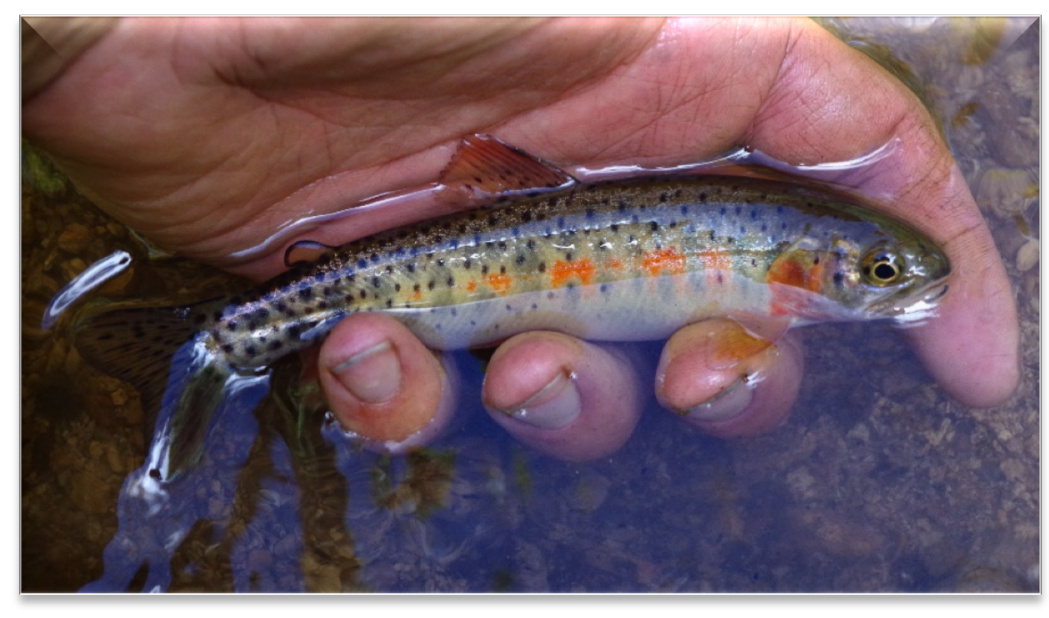

Colorado River cutthroat trout in South Beaver Creek, southwestern Wyoming. Photograph by Carlin Girard, U.S. Geological Survey.
Monitoring work is increasingly focused on the interactions of groundwater and surface water in the WLCI region. The resulting information will help us better understand how land-use and climate changes may affect aquatic systems and human endeavors that rely on southwestern Wyoming's water sources. To that end, in FY2015 we initiated a new study of how groundwater interacts with small streams in an area of oil and gas development in the eastern Wyoming Range. We are focusing on Dry Piney and South Beaver Creek drainages in particular so that we can directly tie

the results to our mechanistic research of fish-community responses to energy resource development in those drainages and enhance our understanding of their native fish community structure and population dynamics. In turn, this information will help planners and managers identify potential conservation actions needed for sustaining those populations.

We continued our long-term monitoring of streamflow and groundwater in the WLCI region at the four established sites in the upper Green River Basin and the Muddy Creek watershed. This project included our first year of data collection from four new groundwater monitoring wells drilled in late FY2014 to pair with existing stream gages in upper and middle portions of the Green River Basin. The paired stream gage and well data are expected to further enhance our understanding of groundwaterstreamflow interactions in the basin, including the extent to which groundwater contributes to streamflow and moderates stream temperatures. In turn, this work also will add to our understanding of how groundwater-streamflow dynamics affect native fish populations in the WLCI region.

Finally, we continued our description of the uppermost geologic units in the WLCI region and analysis of groundwater elevations found in these geologic units. This included publication of a map and accompanying report that illustrate the general north-to-south flow, factors that drive deviations from that general pattern, and levels (including changes) of groundwater in the shallow (lower Tertiary) aquifer system that underlies the Green River Basin (Bartos and others, 2015). We also collected a geologic core from a new, shallow, flowing well drilled into the Wasatch Formation, part of the lower Tertiary aquifer system. The core will enhance our understanding of the composition of the Wasatch Formation in southwestern Wyoming, and the well will be incorporated into our groundwater monitoring efforts in the area.

\section{Effectiveness Monitoring}

Our Effectiveness Monitoring projects directly address the WLCI management need to evaluate effectiveness of habitat treatment projects, as well as restoration, reclamation, and mitigation activities. These activities also address the management need to develop an integrated inventory and monitoring 
strategy, including the objectives to evaluate habitat treatments and best management practices. In addition, Effectiveness Monitoring activities address the objective to make monitoring data available to WLCI partners, and some entail developing and testing innovative methods for maximizing the efficiency and efficacy of monitoring efforts. Finally, our Effectiveness Monitoring activities also indirectly support objectives associated with the management need to identify the condition and distribution of some key habitats and wildlife habitat needs/use.

In FY2015, we continued to focus a significant portion of our Effectiveness Monitoring efforts on developing and testing approaches for monitoring plant phenology (timing and progression of greenup and senescence) to enhance our understanding of animal-vegetation interactions and associated management needs. Our work includes continued near-surface monitoring (with mantis sensors) of plant greenness and soil moisture and temperature at Quickbird Site 1. Additionally, we are collaborating with the USGS North Central Climate Science Center to analyze correlations between plant greenness data acquired by satellite, near-surface sensors, and a PhenoCam remote video recorder (Miller and others, 2015). The results will help us to refine approaches for describing and assessing plant phenology across landscapes, which, in turn, will help managers to better understand animal responses and habitat management needs. Indeed, our phenology work includes collaborating with USGS scientists conducting our WLCI mechanistic study of mule deer and with Ellen Aikens on the Wyoming Range Mule Deer Project to study effects of plant phenology on mule deer migrations, foraging efficiency, and fitness.

A next step in our phenology work is to test the use of plant phenology data for detecting "greenspots" on the landscape that could serve as indicators of habitat treatment effectiveness and the productivity of migration stopovers. This same approach also may be leveraged to identify areas of sagebrush defoliation (opposite of greenspots) and other aspects of phenological interest in the sagebrush system. Not only would that enhance our ability to quantify and monitor components of sagebrush systems, it could help us to evaluate the quality of those habitats.

Tied in with our work to evaluate mule deer habitat is our ongoing effort to map, characterize, and monitor mixed mountain shrub communities, a WLCI crucial habitat type identified in the Wyoming Range Mule Deer Habitat Plan. We continue to collect field data for enhancing the number of shrub species and spatial accuracy of the current shrubland map. We also combined satellite imagery and field data to model site suitability for mountain shrub occurrence, and we initiated vegetation sampling to characterize and monitor shrub community structure and condition in relation to shrub patch distance from oil and gas well pads. In FY2016, we

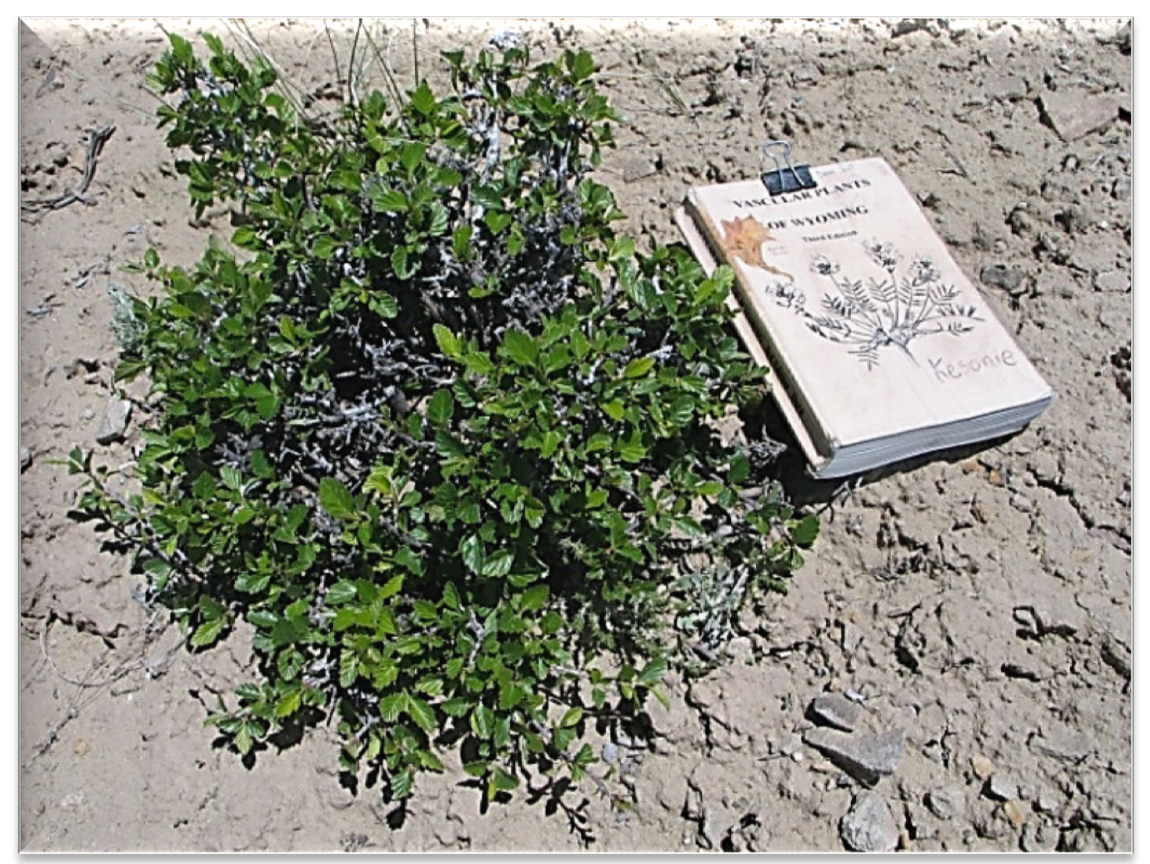

Intensively browsed mountain mahogany near LaBarge, Wyoming. Photograph by David Kesonie, U.S. Geological Survey. 
will apply a new protocol we developed in FY2015 for reconstructing browsing histories in mountain shrub communities to better understand current and projected distribution and condition of these important communities. Combined, approaches and products of this study will help managers identify existing and potential patches of mixed mountain shrubs; understand how they respond to browsing, energy resource development, and other factors; and where restoration and conservation efforts may maximize the coverage of this important habitat type.

Aspen woodland is another WLCI focal habitat type we are studying closely to better understand effects of disturbances and management practices on these woodlands. One of our aspen studies entails using remote sensing for assessing the distribution, condition, and trends in aspen woodlands of the Little Mountain Ecosystem. Although these semiarid woodlands provide crucial habitat for many wildlife species, they are at or near the edge of their range with respect to moisture availability and drought tolerance. The map products resulting from this work provide detailed information about the amount and distribution patterns of mixed aspen-conifer forest and isolated aspen woodlands, thus filling important data gaps. The information has been provided to WLCI partners, and a final set of products are in production to illustrate the timing, extent, and overall effects of drought on the productivity of these woodlands. Our FY2015 accomplishments include a publication and describing this study (Assal and others, 2015).

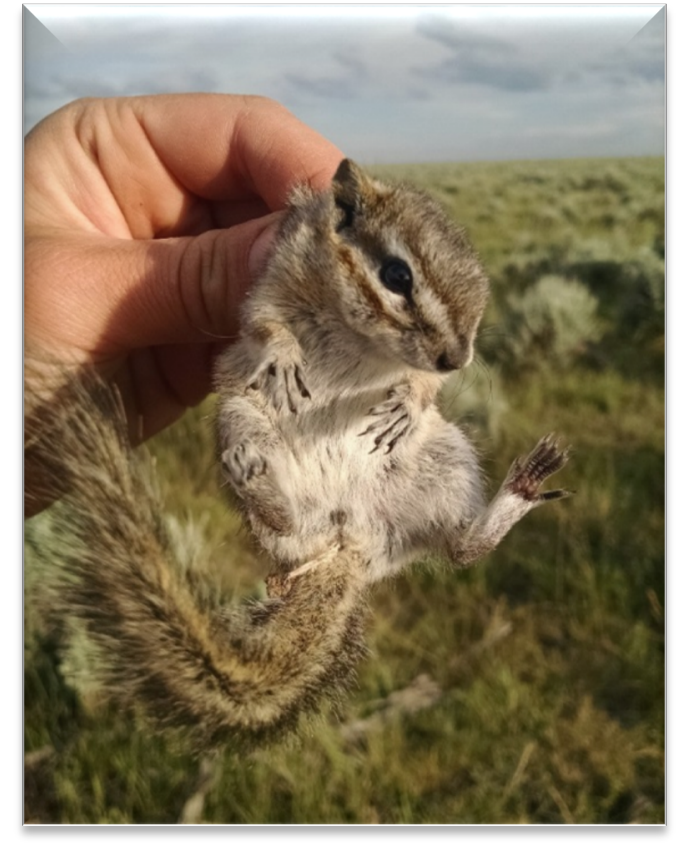

Least chipmunk captured on the Jonah gas field during diurnal small mammal trapping efforts for the sagebrush obligate songbird study. Photograph by Lindsey Sanders, University of Wyoming.

\section{Mechanistic Studies of Wildlife}

Our Mechanistic Studies of Wildlife directly address the WLCI management needs to evaluate the responses of wildlife to development, and to identify the condition and distribution of key wildlife species and habitats and species' habitat requirements. They also help to address the management need to identify key drivers of change and some of the objectives associated with developing an integrated inventory and monitoring strategy (tables 1 and 2).

Our five Mechanistic Studies of Wildlife ${ }^{1}$ target a number of WLCI focal species: pygmy rabbit, sage-grouse, sagebrush-obligate songbirds, mule deer, and native fish, all of which are listed as Wyoming Species of Greatest Conservation Need, and three of which inhabit sagebrush almost exclusively. The overall focus of all our mechanistic studies is to better understand the effects of energy resource development and related activities on wildlife. This includes assessing the ways in which development affects animal community structure and population dynamics, access to and use of seasonal habitats, habitat quality and distribution, and other factors associated with species' population viability. By conducting successive phases of research that build on the knowledge gained through prior phases, our Mechanistic Studies of Wildlife have been evolving from ascertaining how wildlife species respond to energy resource development to what drives their

\footnotetext{
${ }^{1}$ All five Mechanistic Studies of Wildlife have been ongoing since 2008, with the exception of the fish study, which was initiated in 2013.
} 
responses and why they respond as they do. A current focus of these studies is to collaborate with our Land-Cover/Land-Use modeling and simulation ecologist to use simulated alternative scenarios for energy development to assess species responses to the alternatives. Species abundance and habitat occupancy data also help to build the baseline for long-term monitoring.

\section{Sagebrush-Obligate Species}

Our FY2015 pygmy rabbit accomplishments included completing the work of defining and mapping high-, moderate-, and marginal-quality pygmy rabbit habitat under the jurisdiction of the BLM's Kemmerer Field Office. We also analyzed our pygmy rabbit occupancy and abundance data in relation to development levels within each of four major gas fields, and we simulated effects of future oil and gas development scenarios on the distribution of pygmy rabbit habitat (see Baseline Synthesis accomplishments above). We also prepared a manuscript on modeling the distribution of pygmy rabbits and characterizing habitat suitability in Wyoming. Collectively, the successive phases of our pygmy rabbit research and products have validated existing pygmy rabbit habitat maps, provided new information on pygmy rabbit distribution and habitat associations, described variation in pygmy rabbit habitat quality, and provided information about the potential for conflicts (spatial overlap) between pygmy rabbits and energy resource development (natural gas and wind).

Phase I of the sagebrush-obligate songbird study initially entailed assessing songbird abundance and nest survival along a gradient of increasing density of energy resource development. After detecting decreasing abundance and nest survival with increasing well pad density, we initiated Phase II by correlating landscape variable(s) with our earlier findings, recording nest predator events, and conducting surveys of nest predators. Most nest failures resulted from rodent predation, and detections of those predator species increased as well pad density also increased. Working under the hypothesis that energy resource development alters the habitat in a way that also alters predator communities and activities, we are conducting Phase III, which includes a mark-recapture study to estimate rodent densities and ascertain how predator communities vary along the disturbance gradient. In FY2015, we also published two manuscripts that report the results of Phase II (Heathcoat and Chalfoun, 2015a, b). With each new phase of research, we are getting closer to

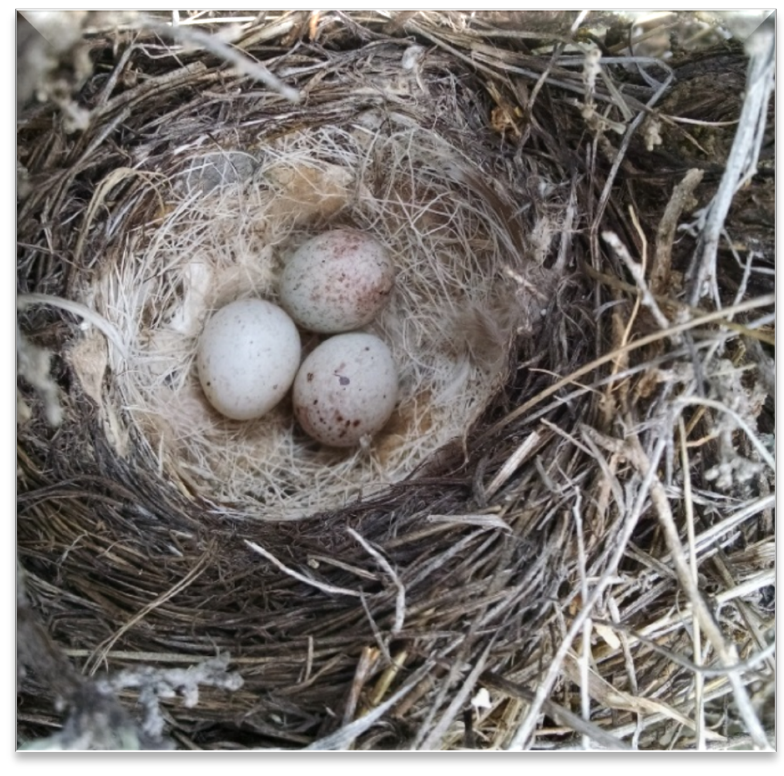

Sagebrush sparrow nest on the Jonah gas field. Photograph by Lindsey Sanders, University of Wyoming. understanding the specific mechanisms driving songbird responses to energy resource development and providing a solid scientific foundation for specific management actions to conserve sagebrush-obligate songbird populations.

Our mechanistic study of greater sage-grouse is currently focused on modeling effects of landscape changes on population demographics and distributions and assessing effects of potential changes on sage-grouse resources and population viability. In FY2015, we ascertained that estimates of population sizes and trends can benefit from sampling existing lek count data over a larger portion of the lekking season than previously believed (Monroe and others, 2016). A subsequent population 
viability analysis indicated that most Wyoming populations are declining across different management zones and population clusters and population persistence depends at least partially on sage-grouse density. We also evaluated sage-grouse population trends relative to timing and intensity of grazing and found that sage-grouse populations increased in dry, low-productivity sites if grazing was limited to early-season and low intensity, but in relatively moist, productive sites populations declined if lateseason, higher intensity grazing occurred. To help identify factors limiting sage-grouse persistence in Wyoming, we developed a spatially explicit model that incorporated sage-grouse behavior, movements, and demographics to predict habitat use, which indicated that habitat outside of protected core areas contributes to core and state-wide populations. We also began to incorporate this model with our LandCover/Land-Use simulations of energy resource development scenarios and climate-induced changes in WLCI sagebrush habitat to provide a better understanding of how they may affect long-term persistence of Wyoming's sage-grouse populations. In FY2015, we published the seasonal habitat modelling and sage-grouse habitat prioritization work (O’Donnell and others, 2015; see http://dx.doi.org/10.3133/ds891), and we submitted two manuscripts for review: one on the lek count timing analysis and another about modeling effects energy resource development on sage-grouse. Combined, the products of our sage-grouse research are building a robust foundation for long-term sage-grouse monitoring in Wyoming and, possibly across the species' range.

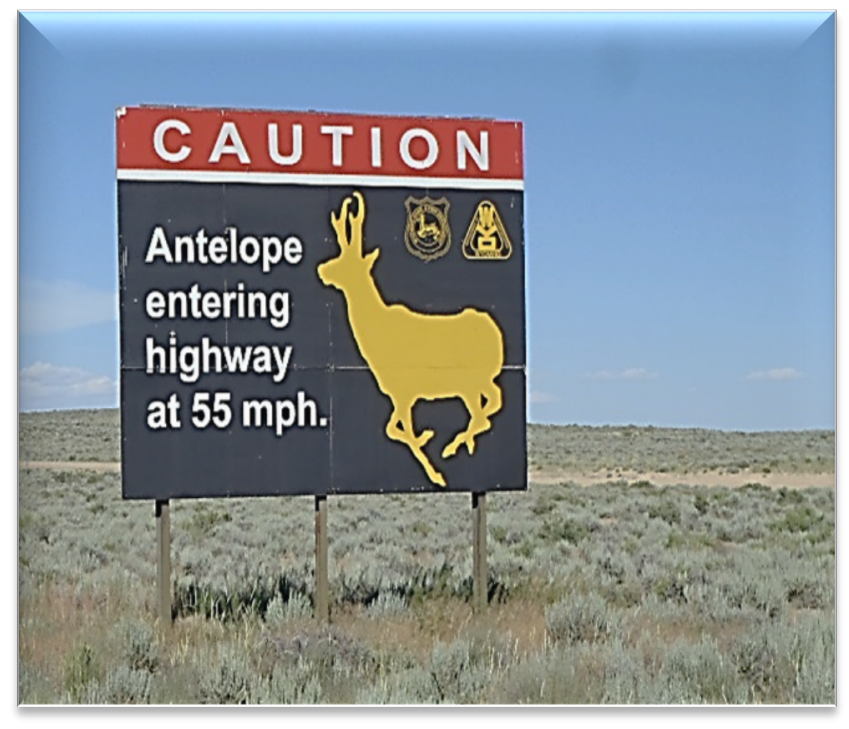

A warning to motorists to be alert for wildlife crossing Route 28 southwest of Farson, Wyoming. Photograph by Cynthia Melcher, U.S. Geological Survey.
Mule Deer

Our Mechanistic study of mule deer continues to advance our understanding of barriers that impede mule deer migrations and foraging efficiency along their migration routes. We know that impermeable barriers (such as tall fences) have obvious and detrimental effects on ungulate migration, but the effects of semipermeable barriers (such as energy resource development fields) are unclear. By analyzing the movements of mule deer fitted with satellite-radio transmitters, we found that deer moved more quickly through developed areas, avoided and spent 35 percent less time in stopover sites affected by development, and avoided rapidly developed areas. Fidelity to migration routes and stopover areas, however, was not influenced by development except where development had occurred rapidly. That is, rather than change their

routes and stopover sites, mule deer alter their movement rates and timing; in turn, this could have demographic consequences. Collectively, the information being generated by this research is providing decisionmakers and managers with the foundation necessary for conserving Wyoming's populations of migratory ungulates. Indeed, some of the information has already driven certain management actions to help reduce the effects of migration barriers.

\section{Native Fish Communities}

To reveal the factors that affect native fish communities, including oil and natural gas development, in the Upper Green watershed, we are assessing how habitat parameters influence fish 
distributions. In FY2015, we continued collecting field data and expanded the study by collaborating with our WLCI hydrological scientists to characterize the hydrology of our study streams. A Master's thesis detailing the approaches and results of our earlier work was completed (Girard, 2015), and two additional manuscripts reporting on the differential vulnerabilities of fish species to energy resource development and approaches for assessing the water chemistry were drafted. Results of this work indicate that the presence of cutthroat trout and mottled sculpin appears to be influenced by willow cover and substrate composition, whereas the mountain sucker appears to be influenced more by slope and water temperature. We also found that oil and gas development can influence habitat and water quality, most likely as a result of sedimentation and reduced willow cover associated with surface disturbance and petroleum spills. Not surprisingly, variations in species' habitat requirements contributed to variation in their vulnerabilities to oil and gas development. The information being gleaned from this work can help land managers focus conservation efforts on reducing effects of surface disturbances and precluding spills or effects of spilled contaminants.

Data and Information Management Accomplishments: Providing a Web-Based Infrastructure for Managing and Accessing WLCI Data and Products

The Data and Information Management activities directly address the management need to develop a data clearinghouse (data catalog) and information management framework; they also directly and indirectly support and provide access to outcomes of most USGS WLCI projects for addressing primary WLCI management needs, particularly the need to develop an integrated inventory and monitoring system (a major component of the data catalog) (tables 1 and 2).

The WLCI Web site and Data Catalog provide the necessary capacities for uploading, cataloguing, archiving, displaying, and serving data and other information for WLCI partners. In FY2015, we continued to update content of the WLCI Web site, including the WLCI Data catalog and WLCI project information, enhance data accessibility, and provide tools that allow users to quickly and conveniently explore WLCI data. An important accomplishment was to update (replace) the datasets displayed in two of the map viewers: (1) a digital representation of 15,532 oil and natural gas well pad scars (another 1,872 possible well pad scars) and other features associated with oil and gas extraction in southwestern Wyoming (Garman and McBeth, 2014; updated with Garman and McBeth, 2015), and (2) an energy map for southwestern Wyoming that shows oil and gas, oil shale, uranium, and solar energy production (Biewick and Wilson, 2014). We also developed a map viewer for the energy map of southwestern Wyoming that shows coal and wind production (Biewick and Jones, 2012), which includes not only energy production infrastructure, but also sage-grouse distribution and core management areas. Finally, we updated the map viewer application to give users additional base map options. All three map products are accessible at https://www.wlci.gov/wlciMapviewer/. 


\section{Project Reports: Baseline Synthesis}

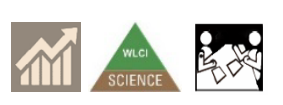

\section{Application of Comprehensive Assessment to Support Decisionmaking and Conservation Actions}

The comprehensive assessment is a collaborative, two-part effort to support WLCI data needs and efforts. Part one entails directing data synthesis and assessment activities to support Local Project Development Teams and the WLCI Coordination Team in their efforts to develop conservation priorities and strategies, identify priority areas for future conservation actions, support evaluation and ranking of conservation projects, and evaluate the ways in which proposed habitat projects relate to WLCI priorities, spatially and ecologically. In FY2015, we assisted the WLCI Coordination Team with updating the WLCI Conservation Action Plan and associated habitat treatment spatial database with information from FY2014 habitat projects, assisted with the BLM WLCI annual report, and provided maps and other materials to support evaluations and rankings of 2016 WLCI conservation projects. We then used the habitat treatment database to update WLCI Web pages pertaining to conservation projects. The Comprehensive Assessment project also provides fiscal support for the development and publication of the USGS WLCI annual reports, and in FY2014 it also supported USGS field, laboratory, and administrative efforts to evaluate sagebrush defoliation/mortality.

Part two of the Comprehensive Assessment entails a multidisciplinary Integrated Assessment (IA) of factors affecting successful conservation and management across the WLCI region. The IA supports decisionmaking at the WLCI programmatic level and conservation planning at landscape scales. This includes identifying areas of high conservation and restoration value and those with high development potential, based on the current landscape. The IA also may be used to consider scenarios of potential future development for evaluating the conservation and restoration potential of a given area. It addresses priority WLCI resources and their condition, agents of change, and potential future conditions as they relate to development and climate change, and it provides WLCI partners with a framework for reassessments in the future. The IA also allows users to decompose the results (transparency) and evaluate resources individually. A variety of logical assumptions based on current knowledge and data availability are inherent to the initial assessments. The IA does not preclude users from incorporating local knowledge into finer-scale assessments to inform local projects for land uses and resource values not considered in the initial effort. In FY2015, we added the WLCI priority areas to the IA Web application for displaying and downloading the data. We also continued to evaluate effects of energy resource development on crucial winter habitat for mule deer and how to use the IA for addressing associated conservation and management questions. In FY2016, we plan to explore available data for information on condition and trends of WLCI focal communities.

\section{Products Completed in FY2015}

- Continued development of the WLCI IA Web application, at http://www.wlci.gov/integrated_assessment.

Contacts: Patrick J. Anderson, 970-226-9488, andersonpj@usgs.gov; Timothy J. Assal, 970-226-9134, assalt@usgs.gov; Zachary H. Bowen, 970-225-9218, bowenz@usgs.gov; Marie K. Dematatis, 970-2269217,mdematatis@usgs.gov 


\section{Modeling Land-Use/Land-Cover Change}

The goal of this project is to develop and use simulations of future oil and gas development patterns and assess their potential effects on wildlife habitat in southwestern Wyoming. This entails using existing energy build-out specifications to locate new oil and gas well pads, wells, and roads on the landscape at annual time steps. Published results of species' responses to well pad, well, and road densities are used to assess potential effects of future development on wildlife species. These simulation assessments help to inform design selection by illustrating the trade-offs between alternative designs (such as directional drilling) for a given set of energy-production and conservation goals. A description of the simulation system and results of a simulation study in the Atlantic Rim development area have been published in a WLCI fact sheet and a journal article. In FY2015, we initiated a WLCI-wide simulation study to compare surface disturbance of proposed build-out designs with nine alternative designs that emphasize directional drilling (fewer well pads) and the effects on pygmy rabbit habitat occupancy. Results of this study indicate that, for each reduction of 1,000 well pads, well pad and road surface disturbance declines by 17.7 square kilometers $\left(\mathrm{km}^{2}\right)$ and the amount of pygmy rabbit habitat (with at least a 50 percent probability of occupancy) increases by $22.5 \mathrm{~km}^{2}$. Results also indicate that greater sage-grouse core areas also protect pygmy rabbit habitat. Results of this study will be published as a journal article in FY2016. These simulation efforts address WLCI management needs to refine approaches and models for predicting future scenarios of land-use change and wildlife responses to these changes. Products of this work can help WLCI Local Project Development Teams prioritize habitat projects and provide information to land management agencies on the conservation potential of alternative energy build-out designs.

In FY2015, we completed a regionalization study of southwestern Wyoming landscapes. Regionalization uses spatial patterns to transform a large number of geographic units into a smaller number of similar units and has been applied to land-use, land-cover maps to identify similar landscapes across large regions. We generated a WLCI land-use, land-cover map by using national datasets (LANDFIRE, NHDPlus) and datasets developed specifically for WLCI (oil and gas pad scars and roads). Statistical analysis of the land-use, land-cover map identified 14 generalized landscape types, including mountainous ecosystems (alpine, subalpine, montane, and foothill forests), 4 sagebrush patterns across the WLCI basins, 2 types of oil and gas fields, and other developed areas (such as urban areas, agriculture, and reservoirs). The study highlights the use of these generalized landscape types to identify future potential sage-grouse core areas based on landscape similarities within core areas, and to identify areas outside large energy resource developments for sagebrush mitigation. A journal article detailing this work has been drafted and is in USGS review.

\section{Products Completed in FY2015}

- Garman, S.L., 2015, Forecasting and evaluating patterns of energy resource development in southwestern Wyoming: WLCI Fact Sheet 7, 2 p., at http://pubs.usgs.gov/wlci/fs/7/.

- Garman, S.L., A spatial framework for assessing physical and wildlife impacts of oil and gas development scenarios in southwestern Wyoming: Environmental Modeling and Assessment (in review).

- Garman, S.L., Regionalization of the southwestern Wyoming landscape (internal review).

Contact: Steven L. Garman, 303-236-1353, slgarman@usgs.gov 


\section{Mineral Resources}

The USGS Mineral Resources Program assesses (inorganic) mineral resources, including baseand precious-metals, uranium, and non-metallic resources such as trona, aggregate, sand and gravel. Future effects of mineral development in southwestern Wyoming will depend on the commodities developed and their locations. To identify where such development is most likely to occur and for which minerals, it is important to apply a geologic understanding to known mineral deposits and extrapolate where similar conditions might occur. Mineral resource studies in the WLCI region (figs. 3-4) have included updating the inventory of historic deposits, cataloging current mine workings, tracking the changes of claimed lands over time, and developing an understanding of why the deposits occur where they do. Results of this research provide updated perspectives on mineral resource availability in the WLCI region and insights on future development.

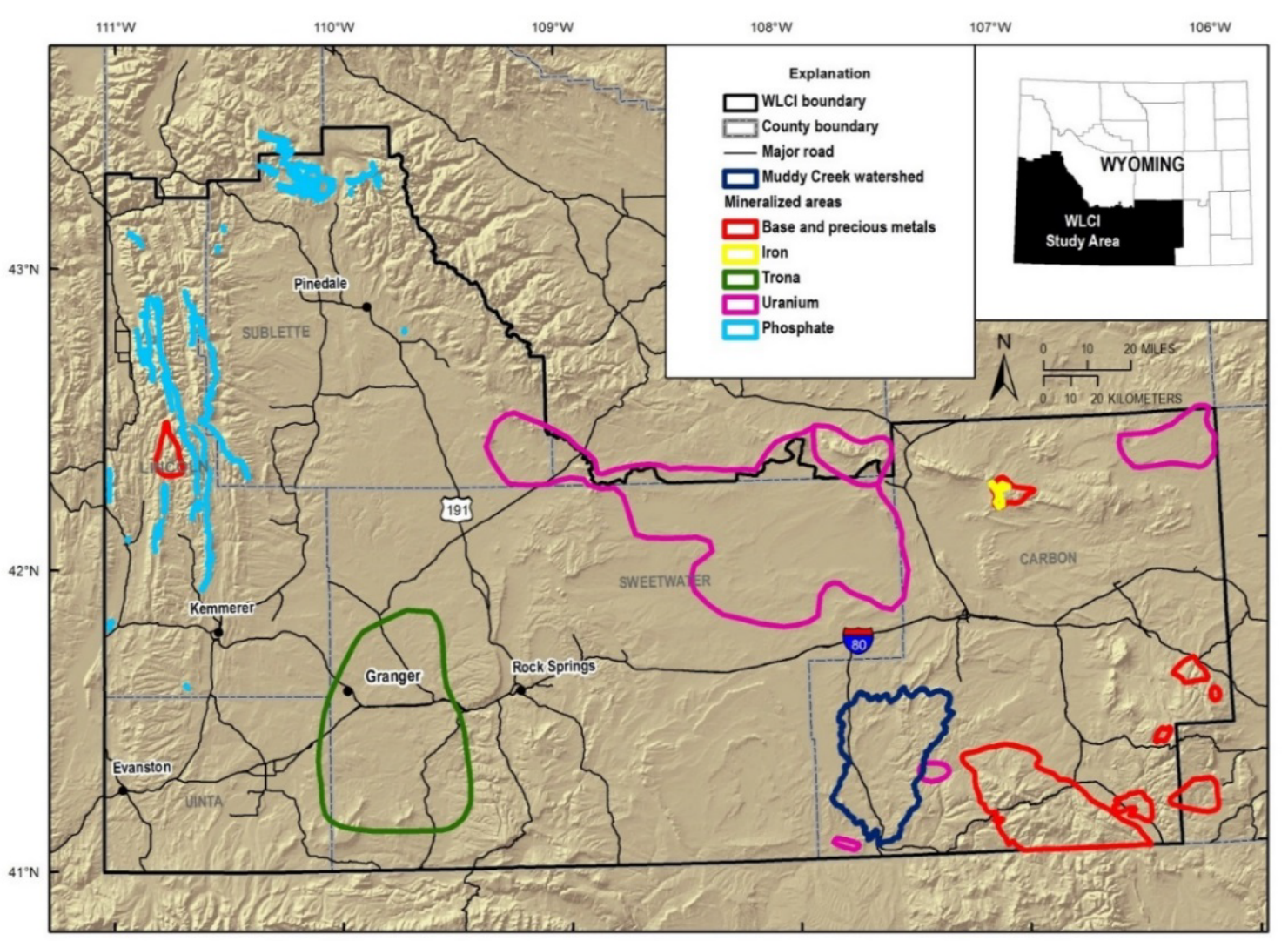

Figure 3. Locations of U.S. Geological Survey's study areas, including mineralized areas, associated with Baseline Synthesis activities in the Wyoming Landscape Conservation Initiative (WLCl) region.

In FY2015, we continued revising an online inventory of mineral resource data, geodatabases, and documentation while preparing final maps and reports. The mineral resource survey of uranium in the study area was published (Wilson, 2015). A summary poster of all the mineral resources was presented at the 2015 WLCI workshop during December in Lander, Wyoming. 


\section{Products Completed in FY2015}

- Wilson, Anna B., 2015, Uranium in the Wyoming Landscape Conservation Initiative study area, southwestern Wyoming: U.S. Geological Survey Open-File Report 2014-1123, at http://dx.doi.org/10.3133/ofr20141123.

Contact: Anna B. Wilson, 303-236-5593, awilson@usgs.gov

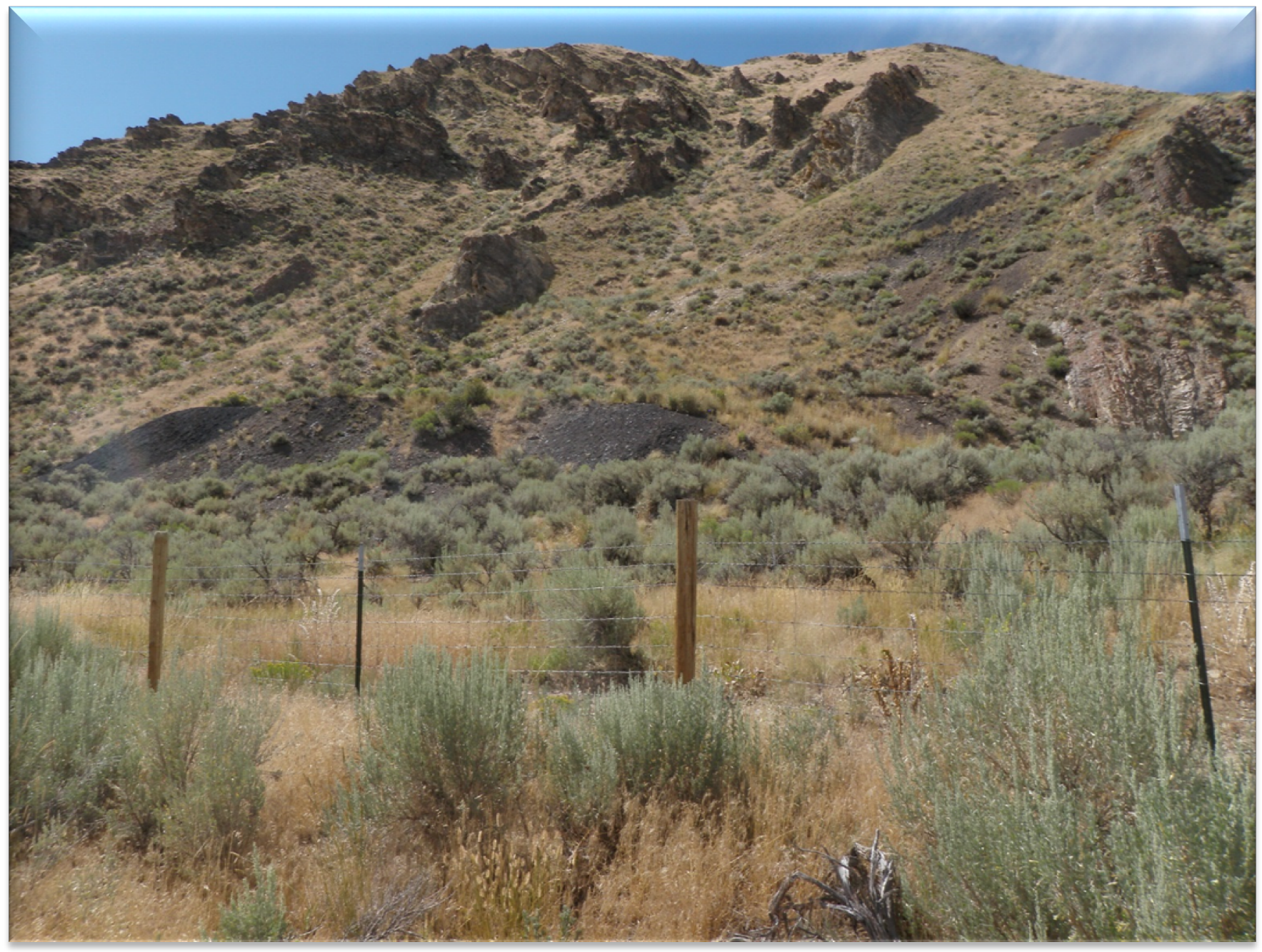

Figure 4. Long-abandoned phosphate mine sites near Cokeville, Wyoming. Photograph by Anna B. Wilson, U.S. Geological Survey. 


\section{Important Agricultural Lands in Southwestern Wyoming}

Agriculture plays an important role in the economic activity and historic identity of people who live within the WLCI boundaries. Improving our understanding of the social and economic values generated by agriculture may help facilitate collaborative conservation efforts and work towards mutually beneficial outcomes. To aid decisionmakers with land-use choices, this study seeks to build upon the information used within the WLCl's Web-based Integrated Assessment to include improved measures of agricultural productivity and historical, ecological, and socioeconomic dimensions of agriculture across the WLCI. As a result, this project will aid the WLCI in further developing an integrated information inventory, and improve upon the data clearinghouse and information management framework.

Identification and cataloging of existing data on the improved measures began in FY2013, and were synthesized into digital maps in FY2014. Identified attributes were then used to construct an index which assigned scores of agricultural importance by watershed (fig. 5). In FY2015, maps of calculated agricultural scores and all underlying data have been made available for upload to the Integrated Assessment. The result is improved access to the best available information on agriculture within the region. This will add value to resources available for stakeholder decisionmaking, and will better assist the WLCI's teams and committees such as the Local Project Development Team. Implications from this work highlight both the practicality of the methods used in this research, but also assumptions required and limitations of characterizing complex societal preferences.

\section{Products Completed in FY2015}

- Results that spatially represent varying levels of agricultural importance; these results and underlying datasets may be used in the Integrated Assessment framework.

- Draft report outlining data sources, methods used, results, and implications for future work.

Contact: Christopher C. Huber, 970-226-9219, chuber@usgs.gov

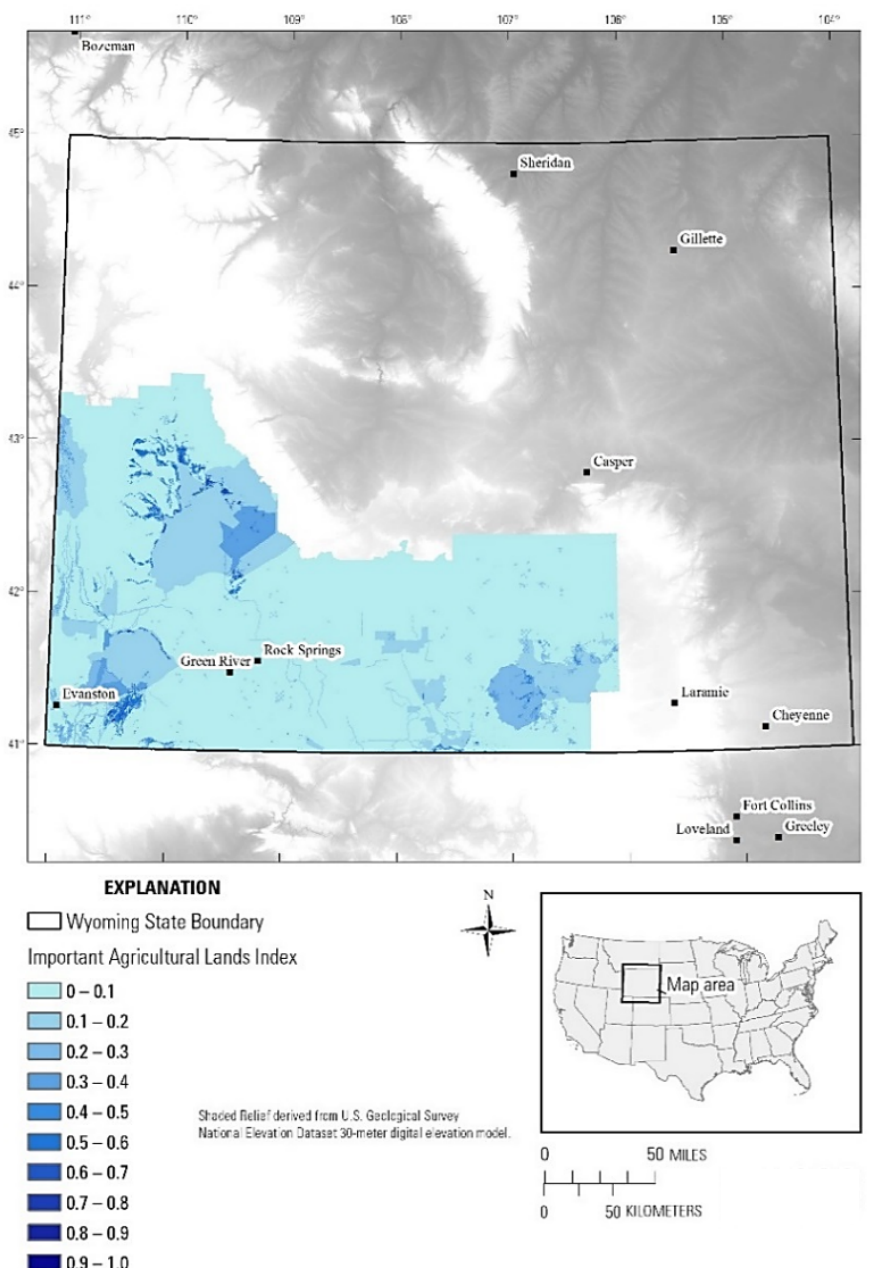

Figure 5. Important agricultural lands index score results for the Wyoming Landscape Conservation Initiative. Based on available data, index results imply varying degrees of aggregate societal value for the ecological, historical, social, and productivity measures supported by agriculture within the region. 


\section{Project Reports: Long-Term Monitoring}

\section{Ti1 Framework and Indicators for Long-Term Monitoring}

Our contributions to long-term monitoring of resource conditions in the WLCI region are founded on remote sensing-based products developed for WLCI projects. The associated data provide a comprehensive, regional perspective on several key indicators of habitat condition, such as cover of shrubs, herbaceous plants, and exposed bare ground. We are supplementing information from our longterm monitoring efforts by assessing correlations between regional monitoring data track local habitat conditions and wildlife behaviors and distributions. Indeed, our Long-Term Monitoring field work and analyses are often integrated with USGS WLCI Effectiveness Monitoring projects and the efforts of our cooperators.

We are developing a collaborative, integrated assessment of habitat conditions by using data acquired from WLCI partners, USGS field efforts, and remote sensing products to describe trends in sagebrush rangelands of southwestern Wyoming. Our current research also includes (1) assessing and monitoring mixed mountain shrub communities (see report on page 44) and defoliated stands of sagebrush (see report on page 33), (2) compiling USGS and partner information for a regional range condition assessment, and (3) assessing trends observed on developed and treated lands to help identify environmental predictors of differences or changes in vegetation dynamics. To leverage the information gained from our work in treated sites, we are coupling it with projects to ascertain abiotic and economic drivers of restoration and mitigation successes and patterns and rates of recovery in post-fire sagebrush. We continue to seek collaborators for compiling and analyzing data and assessing range conditions; if interested, please contact us and (or) join your local (WLCI) Interagency Monitoring Team.

In FY2015, we continued to lead the WLCI Interagency Monitoring Team and catalyze collaborative development of data integration and analyses (among USGS and WLCI partners). We developed a new project to use remotely sensed data for assessing post-disturbance vegetation and habitat dynamics, and we worked closely with the USGS WLCI Effectiveness Monitoring team on its shrub dendrochronology and analyses of vegetation trends (see sagebrush defoliation report below). Finally, we continued to provide technical input and expertise for research designs and projects associated with local project development, post-disturbance vegetation and wildlife dynamics, invasive plant species, and shrubland conservation and management.

\section{Products Completed in FY2015}

- Manier, D.J., Aldridge, C.L., O’Donnell, Michael, and Schell, Spencer, Distribution of nine invasive plant species across a rural, multiple-use landscape in Wyoming (in review).

Contacts: Daniel J. Manier, 970-226-9466, manierd@usgs.gov; Steven L. Garman, 303-202-4118, slgarman@usgs.gov 


\section{Time-Series Analysis of Multi-Resolution Imagery to Quantify Sagebrush Defoliation and Mortality in Southwestern Wyoming (new in FY2015)}

From 2010-14, the Natural Resources Conservation Service (NRCS) and Wyoming Game and Fish Department (WGFD) recorded increased observations of sagebrush mortality in southwestern Wyoming (Clause and Randall, 2014). There is concern that defoliation and (or) mortality events represent additional stressors on sagebrush habitats that could have negative effects on sagebrushobligate species. Indeed, sagebrush mortality has been reported within sage grouse core areas and pronghorn crucial winter habitat. The extent, mechanism, and frequency of these events are unknown at this time and research is needed to help address these data gaps. Ongoing research that uses remote sensing to describe long-term characteristics of sagebrush ecosystems has been successful (see page 35); however, the short time frame (for example, intra-seasonal) associated with sagebrush defoliation or mortality events requires analysis over smaller intervals. Sagebrush communities are one of the five focal ecosystems within the WLCI region and this work will expand the USGS research capacity for the WLCI and develop a framework for assessing potential causes and effects of disturbance in sagebrush ecosystems.

\section{Objectives}

- Ascertain how sagebrush ecosystem productivity is affected by mortality and (or) defoliation events.

- Evaluate the potential for landscape-scale remote sensing data to detect the extent and (or) severity of mortality over time.

- Identify the mechanisms behind these disturbance events.

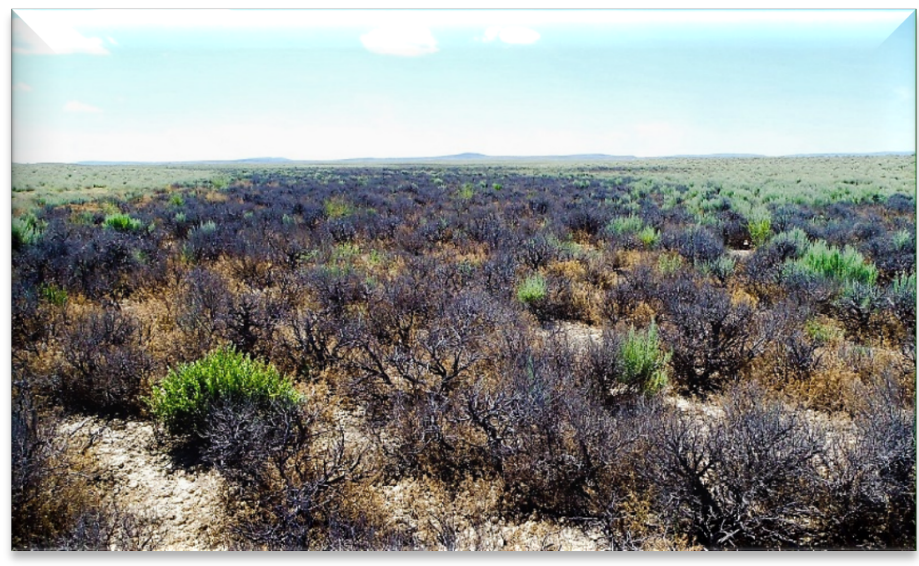

Stand of defoliated sagebrush near Fontanelle, Wyoming (color-enhanced to contrast live versus dead shrubs; the dead patch of sagebrush is in the middle in a drainage, whereas the live sage is on slightly higher ground either side of the drainage; the bright-green live shrubs in the foreground of the dead patch are not sagebrush). Photo credit: Cynthia Melcher, U.S. Geological Survey.

Spectroradiometer (a moderate-resolution sensor aboard the Terra Satellite). The indices will serve as preliminary indicators of plant productivity on biweekly intervals over the duration of the growing season from 2000 to 2015 . We will use this information to identify potential areas of change (that is, areas with anomalous productivity), then calculate the productivity of those areas from Landsat imagery (fine spatial resolution and coarse temporal resolution). We will use field observations from the WGFD, NRCS, and USGS (fig. 6) to identify the annual trajectory of productivity in areas of dead (or defoliated) and healthy sagebrush. We expect areas of mortality or defoliation to exhibit a decrease in productivity over some time period. Using linear trend analysis (Assal and others, 2016), the decrease in productivity can be captured as a deviation from the average long-term productivity of a site. If this approach is successful, we anticipate that collections of additional quantitative field measurements may be necessary to determine levels of severity within areas identified as sagebrush mortality. 
Study Area

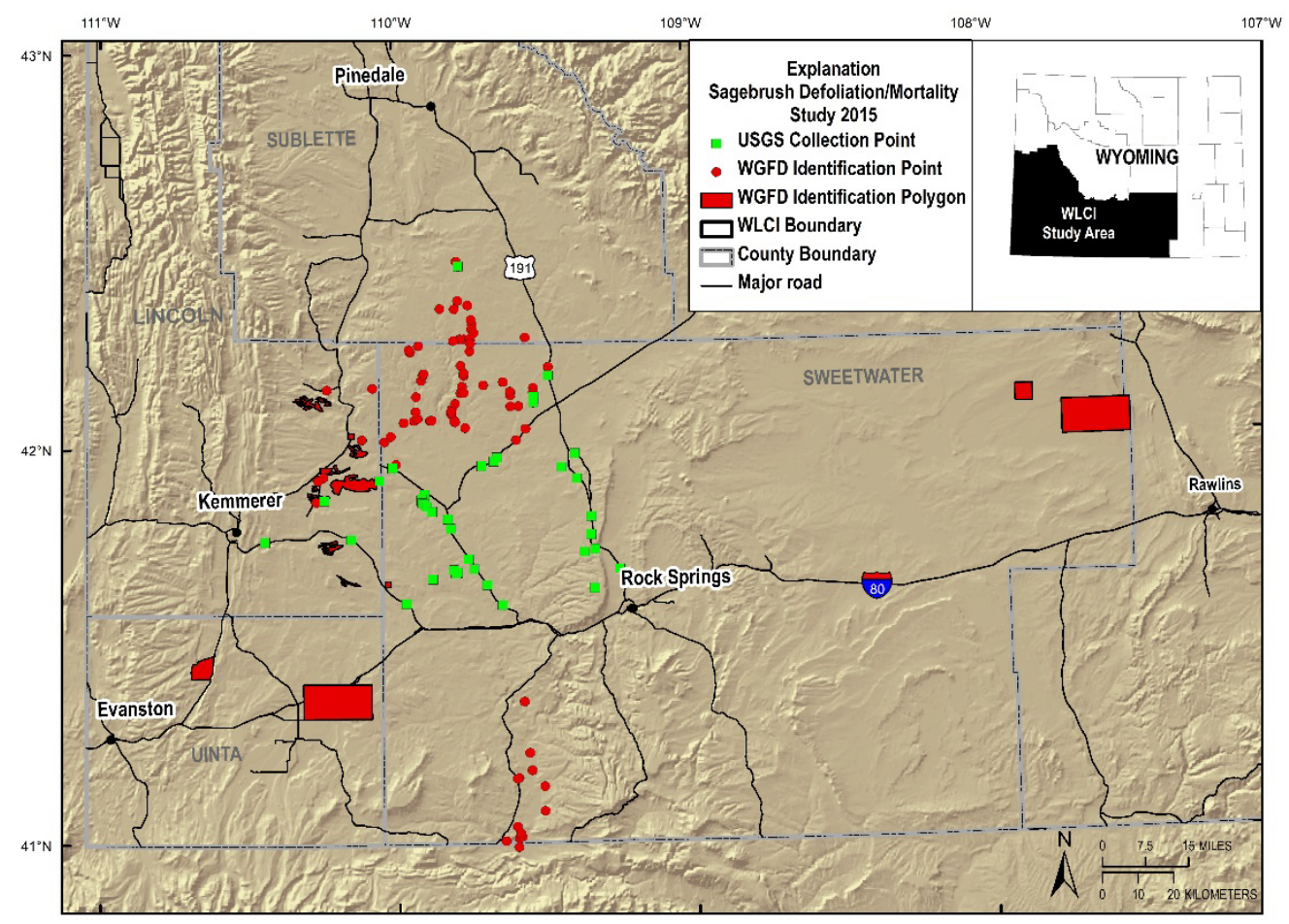

Figure 6. The study area is centered on the western portion of Sweetwater County, southern Sublette County, and eastern Lincoln County. [USGS, U.S. Geological Survey; WGFD, Wyoming Game and Fish Department; WLCl, Wyoming landscape Conservation Initiative]

\section{Work Accomplished in FY2015}

During the summer of 2015, USGS scientists collected information on the status of sagebrush at numerous locations. This information includes locations of dead and (or) defoliated patches of sagebrush, as well as patches of perceived healthy sagebrush to provide context when using remotely sensed imagery for evaluating the stability of sagebrush patches that have not experienced defoliation or mortality. Information collected included photo points and percent cover of sagebrush (live and dead), grass, and forbs. We also acquired Landsat imagery from the USGS EarthExplorer archive for the area of southwestern Wyoming (path 37, row 31) in question for the growing seasons of 2013, 2014, and 2015. From the imagery, we derived vegetation indices as proxies for plant productivity.

\section{Products Completed in FY2015}

- Locations of USGS field observations were added to the sagebrush observation database (shared with WLCI partners).

- Collection of field photos cross referenced with the observation database.

- Remote sensing datasets assembled from satellite imagery archive.

Contact: Timothy J. Assal, 970-226-9134, assalt@usgs.gov 


\section{Remote Sensing and Vegetation Inventory and Monitoring}

This project is founded on using remote-sensing tools and protocols for monitoring long-term changes in vegetation cover across the WLCI region. This information is crucial for understanding patterns of change within sagebrush habitats. We characterize vegetation changes by monitoring five major components of vegetation cover: all shrubs, sagebrush, herbaceous vegetation, litter, and bare ground. Based on samples collected both in the field and from satellite imagery, we can quantify longterm changes in vegetation cover and distribution. This work and associated products represent the operational WLCI vegetation monitoring effort and provide input to a broad spectrum of on-going WLCI research and applications.

During FY2015, we monitored and analyzed vegetation change in several ways. First, we analyzed archived Landsat imagery to reveal historical conditions, and then we measured 1985-2010 trends in sagebrush, herbaceous, and bare ground cover across the entire WLCI region for 10 time periods. Various factors led to vegetation changes, including fire, human disturbance, and climate. Focusing on just sagebrush and climate results indicated that declines in precipitation accounted for a decrease in sagebrush (from 8.9 to 8.66 percent) (fig. 7) and an increase in bare ground (from 63 to 63.7 percent). Second, we continued monitoring along 260 marked vegetation transects distributed across two QuickBird study sites. Sampled since 2006, the transect data provide a decade-long record that we can use to understand ground level changes and validate our remote-sensing protocols. Finally, we published the results of our analysis to understand whether vegetation changes track precipitation changes since 1985 and used those results to develop a model for predicting vegetation changes. Based on projections of ongoing declines in amounts of precipitation (to 2050), sagebrush cover would keep declining and bare ground would continue increasing.

\section{Products Completed in FY2015}

- Homer, C.G., Xian, George, Aldridge, C.L., Meyer, D.K., Loveland, T.R., and O’Donnell, M.S., 2015, Forecasting sagebrush ecosystem components and greater sage-grouse habitat for 2050: Learning from past climate patterns and Landsat imagery to predict the future: Ecological Indicators, v. 55, p. 131-145.

- Analysis of changes in cover of sagebrush, herbaceous vegetation, and bare ground for 10 periods from 1985 to 2010.

- Continued vegetation measurements in 260 marked long-term monitoring transect plots, and completed field work necessary for re-mapping vegetation cover for 2015 across the WLCI region (to include all shrubs, sagebrush, big sagebrush, bare ground, herbaceous and annual herbaceous vegetation, litter, shrub height, and sagebrush height).

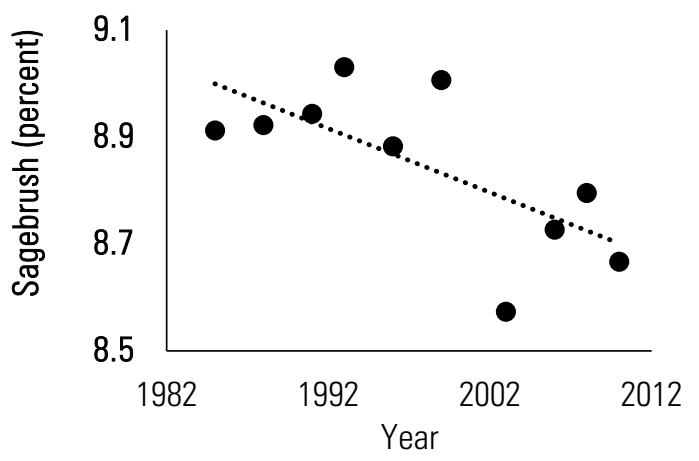

Contacts: Collin G. Homer, 208-426-5213, homer@usgs.gov; Cameron L. Aldridge, 970-226-9433, aldridgec@usgs.gov

Figure 7. Change in percent cover of sagebrush across the Wyoming Landscape Conservation Initiative region from 1985-2010, as measured from Landsat satellite data for sampled years. 


\section{Long-Term Monitoring of Surface Water, Groundwater, and Water Quality}

Riparian and aquatic ecosystems in semiarid landscapes like southwestern Wyoming contribute substantially to regional biodiversity. Long-term monitoring data that describe streamflow, surfacewater quality, and groundwater levels are needed for assessing possible effects of changing land use, land cover, and climate on those ecosystems. With WLCI funding, we have been monitoring streamflow and surface-water quality at four sites and groundwater levels at four sites (fig. 8). Sites were selected to provide baseline characterization of the upper Green River Basin and Muddy Creek watersheds. Data are collected according to USGS methods (Wagner and others, 2006; Kenney, 2010; Sauer and Turnipseed, 2010; Turnipseed and Sauer, 2010; U.S. Geological Survey, variously dated). This project helps to address WLCI inventory and monitoring needs for evaluating effectiveness of habitat projects and supporting assessments of cumulative effects of change.

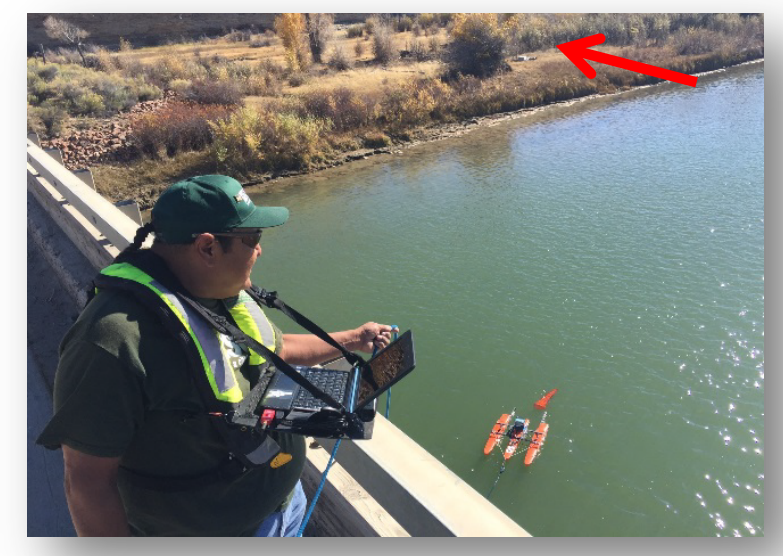

Measuring streamflow with an acoustic Doppler current profiler in the Green River near LaBarge, just upstream of Fontenelle Reservoir, Wyoming. The red arrow points to one of the two streambank wells at this site. Photograph by Jerrod Wheeler, U.S. Geological Survey.

In March 2015, we installed instruments to measure the water elevation and temperature in four new groundwater-monitoring wells drilled during late FY2014, one on each side of the New Fork River streambank near Big Piney (blue triangle in upper white circle, fig. 8) and one on each side of the Green River streambank near LaBarge (blue triangle in lower white circle, fig. 8). During FY2015, we

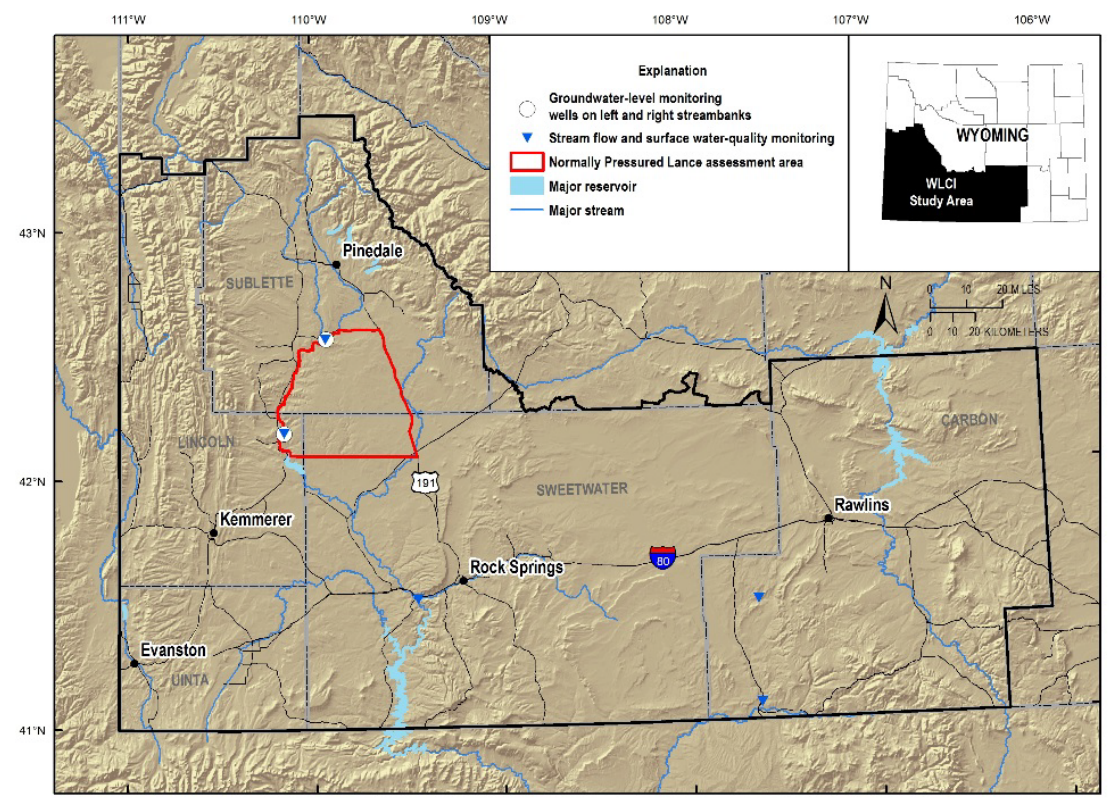
continued to collect surface waterquality data at the four sites in the upper Green River Basin and Muddy Creek watershed (fig. 8), and we initiated groundwater-level data collection at the four new streambank wells. In cooperation with the State of Wyoming, BLM, and Bureau of Reclamation, additional surface water-quality and quantity data were collected in the WLCI area to enlarge the water-resources dataset that can be used to support resource management and research in the WLCI study area and beyond.

Figure 8. Locations of U.S. Geological Survey's field-based study areas associated with Long-Term Monitoring projects during FY2015 in the Wyoming Landscape Conservation Initiative region. 
Well data are revealing interactions between surface water and groundwater in the area's shallow aquifers. For example, differences in water elevations between the New Fork west bank well and the river indicate that groundwater is discharging into the river during spring and summer (fig. 9), adding to the streamflow coming from upstream. The cooler groundwater discharge also moderates the river's summertime temperature fluctuations. Long-term data from these new wells are crucial for understanding how groundwater contributes to streamflows in the Green River Basin and may help to inform water-resource management in the basin overall. Activities that affect groundwater also have the potential to affect surface water. Understanding the interactions between groundwater and surface water will help managers make informed decisions to mitigate potential effects of land-use changes on water resources.

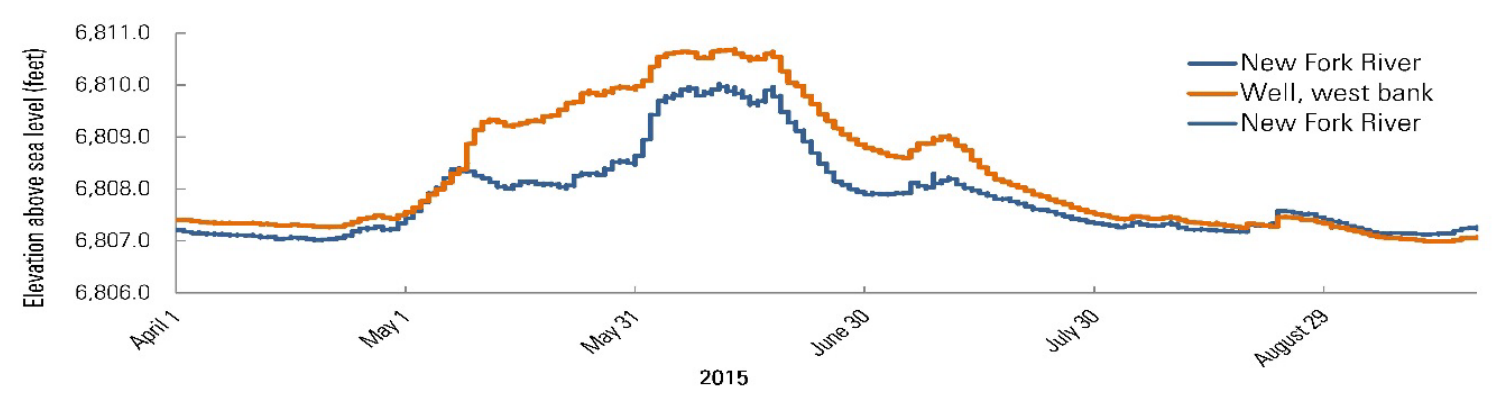

Figure 9. Elevation of New Fork River and associated streambank well from April 1 to September 30, 2015.

\section{Products Completed in FY2015}

- For all monitoring sites, preliminary data are available in real time, and for each site there is an annual report that finalizes and summarizes the data (table 4).

Contact: Cheryl A. Eddy-Miller, 307-775-9167, cemiller@usgs.gov; Kirk A. Miller, 307-775-9168, kmiller@usgs.gov

Table 4. Products of 2015 work on long-term monitoring or surface water, groundwater, and water quality.

\begin{tabular}{|c|c|}
\hline Real-Time and Water-Quality Data & Annual Report \\
\hline \multicolumn{2}{|c|}{ New Fork River near Big Piney, Wyoming } \\
\hline $\begin{array}{l}\text { http://waterdata.usgs.gov/wy/nwis/uv/?site_no }=0 \\
9205000\end{array}$ & $\begin{array}{l}\text { http://waterdata.usgs.gov/nwis/wys_rpt/?site_no }=0 \\
9205000\end{array}$ \\
\hline \multicolumn{2}{|c|}{ Green River near Green River, Wyoming } \\
\hline $\begin{array}{l}\text { http://waterdata.usgs.gov/wy/nwis/uv/?site_no }=0 \\
9217000\end{array}$ & $\begin{array}{l}\text { http://waterdata.usgs.gov/nwis/wys_rpt/?site_no }=0 \\
9217000\end{array}$ \\
\hline \multicolumn{2}{|c|}{ Muddy Creek above Olson Draw, near Dad, Wyoming } \\
\hline $\begin{array}{l}\text { http://waterdata.usgs.gov/wy/nwis/uv/?site_no }=0 \\
9258050\end{array}$ & $\begin{array}{l}\text { http://waterdata.usgs.gov/nwis/wys_rpt/?site_no }=0 \\
9258050\end{array}$ \\
\hline \multicolumn{2}{|c|}{ Muddy Creek below Young Draw, near Baggs, Wyoming } \\
\hline $\begin{array}{l}\text { http://waterdata.usgs.gov/wy/nwis/uv/?site_no }=0 \\
9258980\end{array}$ & $\begin{array}{l}\text { http://waterdata.usgs.gov/nwis/wys_rpt/?site_no }=0 \\
9258980\end{array}$ \\
\hline
\end{tabular}




\section{Analysis of Long-term Groundwater Elevation Data and Geologic Description}

Ongoing natural gas development in the northern Green River structural basin necessitates information about groundwater resources that supply water to the basin's wells. Many human activities in that area, including pumping water from the aquifers for agricultural, domestic, and industrial use, and penetration of the heterogeneous (that is, complex intertonguing of layers) aquifers (Bartos and others, 2015) during deeper drilling for natural gas, have the potential to affect the aquifer system that supplies water to most wells in the area. We initiated this study in FY2012 as a retrospective assessment of groundwater occurrence in the Normally Pressured Lance Formation and a field reconnaissance of existing water wells in the study area. The assessment was completed in 2012, but in 2013, ownership of the mineral rights to develop the Normally Pressured Lance Formation (figs. 8 and 10) was sold and the proposed development there was placed on hold. Therefore, to assist agencies such as the BLM with upcoming development, the emphasis of the study was modified and previously collected data were used to develop a potentiometric-surface map (a visual representation of aquifer-water levels) for the lower Tertiary aquifer system that underlies the Green River Basin.

During 2010-2014, groundwater levels were measured in 89 wells in the area near and within the proposed Normally Pressured Lance Formation Project Area (figs. 8 and 10) (Bartos and others, 2015). Differences in groundwater levels were calculated for 27 sites where a measurement had been collected between 39 and 46 years earlier. During this time period, water levels decreased in most wells (76 percent) between 0.1 and 86.9 feet and increased in the remaining wells between 1.0 and 5.5 feet. The potentiometric-surface map (fig. 10) indicates that direction of groundwater flow in the study area is generally from north to south, but this general pattern is affected locally by groundwater divides, groundwater discharge to the Green River, Fontenelle Reservoir, and possibly by a tributary river (Big Sandy River) and a reservoir (Big Sandy Reservoir). Updated information in the report and potentiometric-surface map can be used for decisions regarding groundwater and to evaluate any future changes in the aquifer system.

In August 2015, a 160 foot-deep flowing well was drilled, and a geologic core was collected from the bore hole. A detailed description of the geology will be completed during FY2016, adding information about the upper water-bearing unit of the heterogeneous Wasatch Formation. Water levels in the completed and capped flowing well will be monitored as part of the long-term monitoring program in the upcoming years. When combined with other WLCI monitoring activities, these water-resources data support resource management and research in the WLCI study area and the region, and will support BLM and other land and resource managers with planning and decisionmaking responsibilities.

\section{Products Completed in FY2015}

- Bartos, T.T., Hallberg, L.L., and Eddy-Miller, C.A., 2015, Hydrogeology, groundwater levels, and generalized potentiometric-surface map of the Green River Basin lower Tertiary aquifer system, 2010-14, in the northern Green River structural basin, Wyoming: U.S. Geological Survey Scientific Investigations Report 2015-5090, 33 p., at http://dx.doi.org/10.3133/sir20155090.

Contact: Cheryl A. Eddy-Miller, 307-775-9167, cemiller@usgs.gov; Timothy T. Bartos, 307-775-9160, ttbartos@usgs.gov

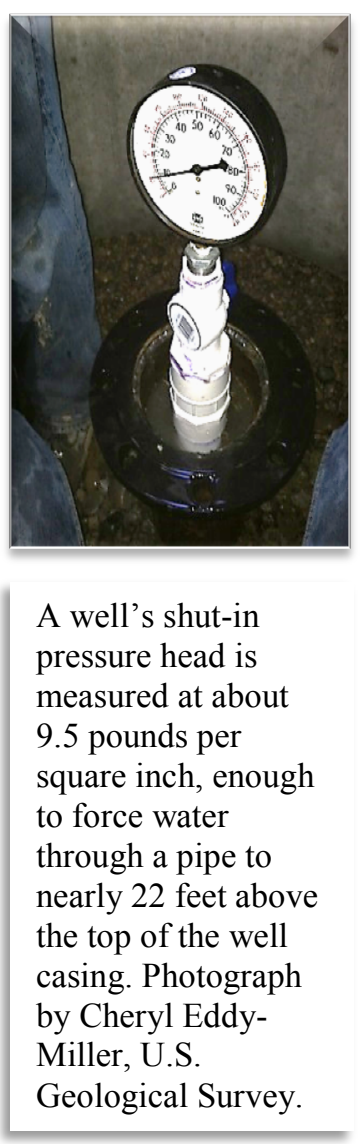




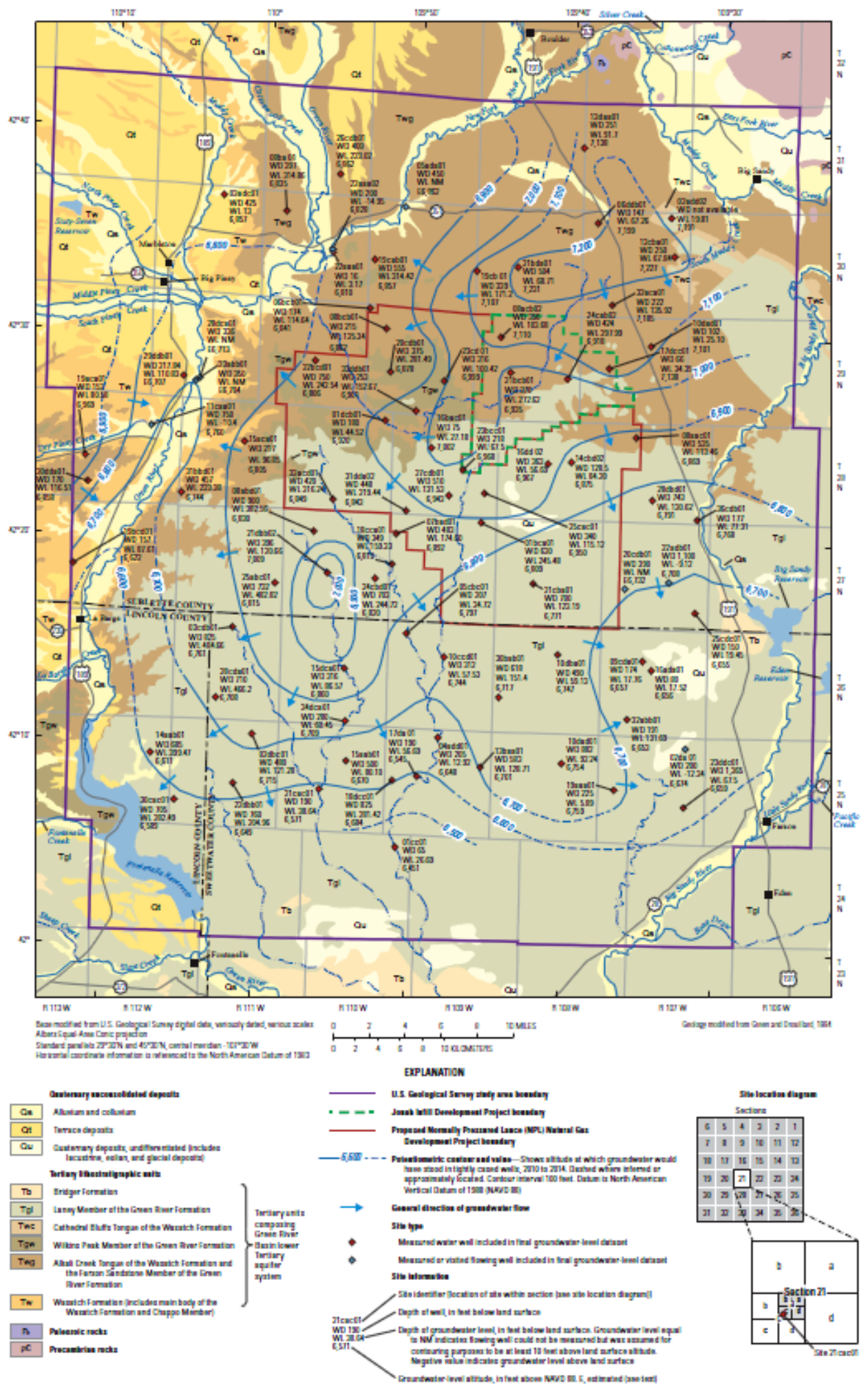

Figure 10. Lines of equal water-level elevation (potentiometric surface) and general direction of groundwater flow in the upper Tertiary Aquifer, in and near the Normally Pressured Lance project boundary (map and full report available at $h$ ttp://dx.doi.org/10.3133/sir20155090). 


\section{Evaluation of Groundwater Interaction with Small Streams in the Western Green River Basin to Enhance Understanding of Aquatic Communities (New in FY2015)}

Since the early 1900s, oil and gas development has occurred on the eastern flank of the Wyoming Range, but in recent years the geographical extent of development has increased. In collaboration with USGS fisheries ecologist, Annika Walters, we are evaluating the effects of this development on native fish species. Evaluations of groundwater interactions with small streams in the Western Green River Basin, as well as precise streamflow measurements, are important components for ascertaining the health of all aquatic species. An understanding of streamflow and in what stream sections it is sustained throughout the year will help us understand changes and differences in aquatic communities.

Streamflow data collected during FY2015 will help with interpretations of the aquatic species distribution data and provide insights into the mechanisms of sustaining small streams in the upper parts of watersheds. These small streams can be crucial for survival of native species, and understanding what controls the streamflow will support resource management decisions in the study area.

\section{Objectives}

- Collect precise streamflow measurements at multiple locations to coincide with fisheries studies sites in the upper Dry Piney and South Beaver Creek drainages.

- Evaluate data to determine where groundwater inflow plays a significant role in sustaining the streamflow.

- Share data and findings with coinvestigators to assist with their analyses.

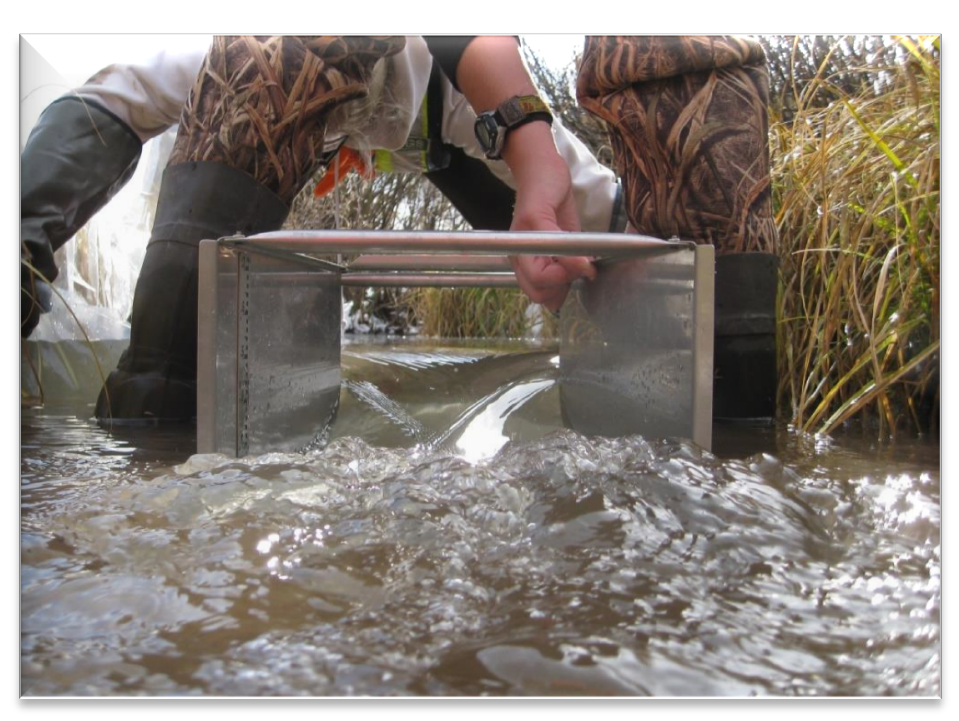

A portable flume is used to accurately measure the small streamflow at this South Beaver Creek site. Most sites in the study area had flows of less than 1 cubic foot per second (7.5 gallons per second) when measured during November 2015. Photograph by Cheryl Eddy-Miller, U.S. Geological Survey.
Methods

Standard USGS methods for measuring streamflow will be used (Wagner and others, 2006; Kenney, 2010; Sauer and Turnipseed, 2010; Turnipseed and Sauer, 2010). Data will be analyzed using standard methods such as those described in Wheeler and Eddy-Miller (2005).

Study Area

Selected sites will correspond with Walters native fish community sites in the South Beaver Creek and Dry Piney Creek drainages on the eastern side of the Wyoming Range (fig.11). 


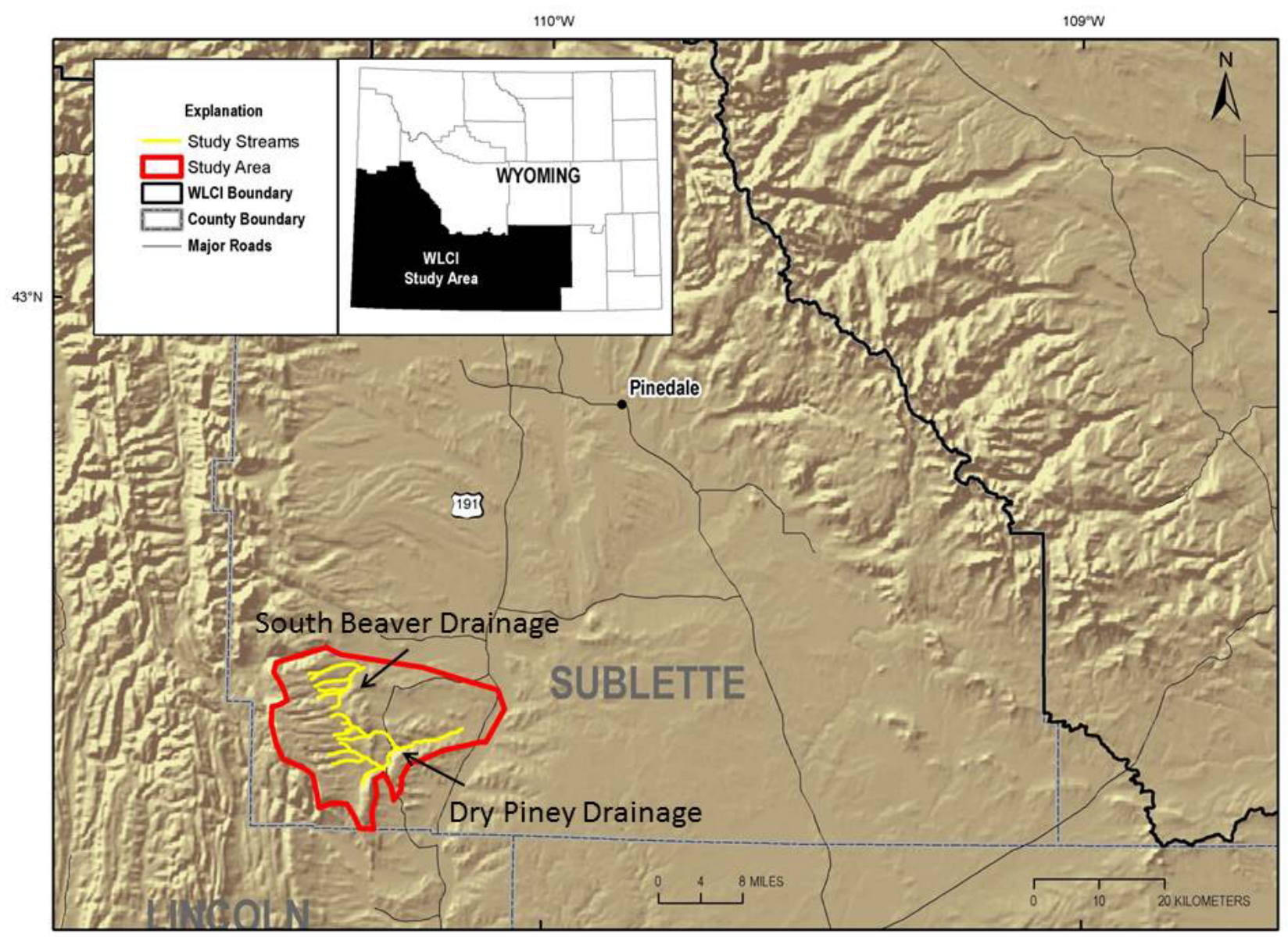

Figure 11. Study area and study streams for evaluating the influence of natural gas development on native fish communities. South Beaver drainage is to the north and Dry Piney drainage is to the south. Map by Carlin Girard, University of Wyoming.

Work Accomplished in FY2015 and Implications of Initial Findings

During June 2015, 25 sites were selected and streamflow was measured at those sites. The same sites were revisited in August and November 2015. As expected, streamflow decreased from the high snowmelt input time of June to August, and decreased again in November. Streamflow was present at all sites through November. Currently, the data are being evaluated to determine which part of the streamflow can be attributed to groundwater flow that can sustain the streams during winter and times of low precipitation and which part of the streamflow is from recent precipitation or snowmelt.

\section{Products Completed in FY2015}

- Streamflow measurements collected during FY2015 are available online at http://wy-mt.water.usgs.gov/projects/wlci/gw_interaction/index.html.

Contacts: Cheryl Eddy-Miller, 307-775-9167, cemiller@usgs.gov 


\section{Project Reports: Effectiveness Monitoring}

\section{A1 Applying Greenness Indices to Evaluate Sagebrush in the WLCI Region}

Weather and climate affect terrestrial wildlife habitat through their influences on plant productivity. Plant phenology - the timing of life-history events such as green-up, flowering, and senescence - provides one indicator of the timing and magnitude of productivity. Spatiotemporal changes and variability in plant phenology are indicators of habitat quality, which is a driver of fitness for WLCI species of concern: elk, mule deer, pronghorn, greater sage-grouse, other wildlife species, and livestock. Measuring and monitoring plant phenology contribute specifically to evaluating and monitoring the effectiveness of management activities related to habitat quality.

In 2015, we continued near-surface vegetation greenness, soil moisture, and temperature monitoring at Quickbird Site 1 (established in 2012) (fig. 12). We collaborated with the USGS North Central Climate Science Center to initiate data analyses to correlate plant greenness data acquired by satellite with near-surface data acquired with mantis sensors (seven installed in 2012) and a PhenoCam (installed in 2014) (Miller and others, 2015). We continued work with Ellen Aikens on the Wyoming Range Mule Deer Project, which includes partial funding from the National Climate Change and Wildlife Science Center. It was found that drought may negatively affect the ability of individual deer to surf the "green wave" efficiently (fig. 13), which may have negative effects on their fitness (body fat and reproduction) (Aikens and others, 2015). We have initiated analyses to use phenology data (plant greenness) to detect "greenspots" as a means to evaluate the effectiveness of habitat treatments, productivity of migration stopovers, areas of sagebrush defoliation (opposite of greenspots), and other areas of interest in the sagebrush system. This work will enhance our ability to quantify and monitor sagebrush habitat quality. Overall, our data and analyses will provide information to managers on habitat quality and advance the science of measuring and monitoring vegetation greenness.

\section{Products Completed in FY2015}

- Chong, Geneva, Miller, Brian, Morisette, Jeffrey, Steltzer, Heidi, Bern, Carleton, Talbert, Marian, Talbert, Colin, and Shory, Rick, 2015, Use of PhenoCam data in a multi-scale evaluation of Wyoming sagebrush phenology: 2015 North Central Climate Science Center Open Science Conference, Fort Collins, Colo., May 20-22, 2015, at http://nccsc.colostate.edu/conference/program.

- Sweet, S.K., Griffin, K.L., Steltzer, Heidi, Gough, Laura, and Boelman, N.T., 2015, Greater deciduous shrub abundance extends tundra peak season and increases modeled net $\mathrm{CO}_{2}$ uptake: Global Change Biology, v. 21, p. 2394-2409, at http://onlinelibrary.wiley.com/doi/10.1111/gcb.12852/abstract.

Contacts: Geneva W. Chong, 307-201-5425, geneva_chong@usgs.gov; Matthew J. Kauffman, 307-7666404,mkauffm1@uwyo.edu 


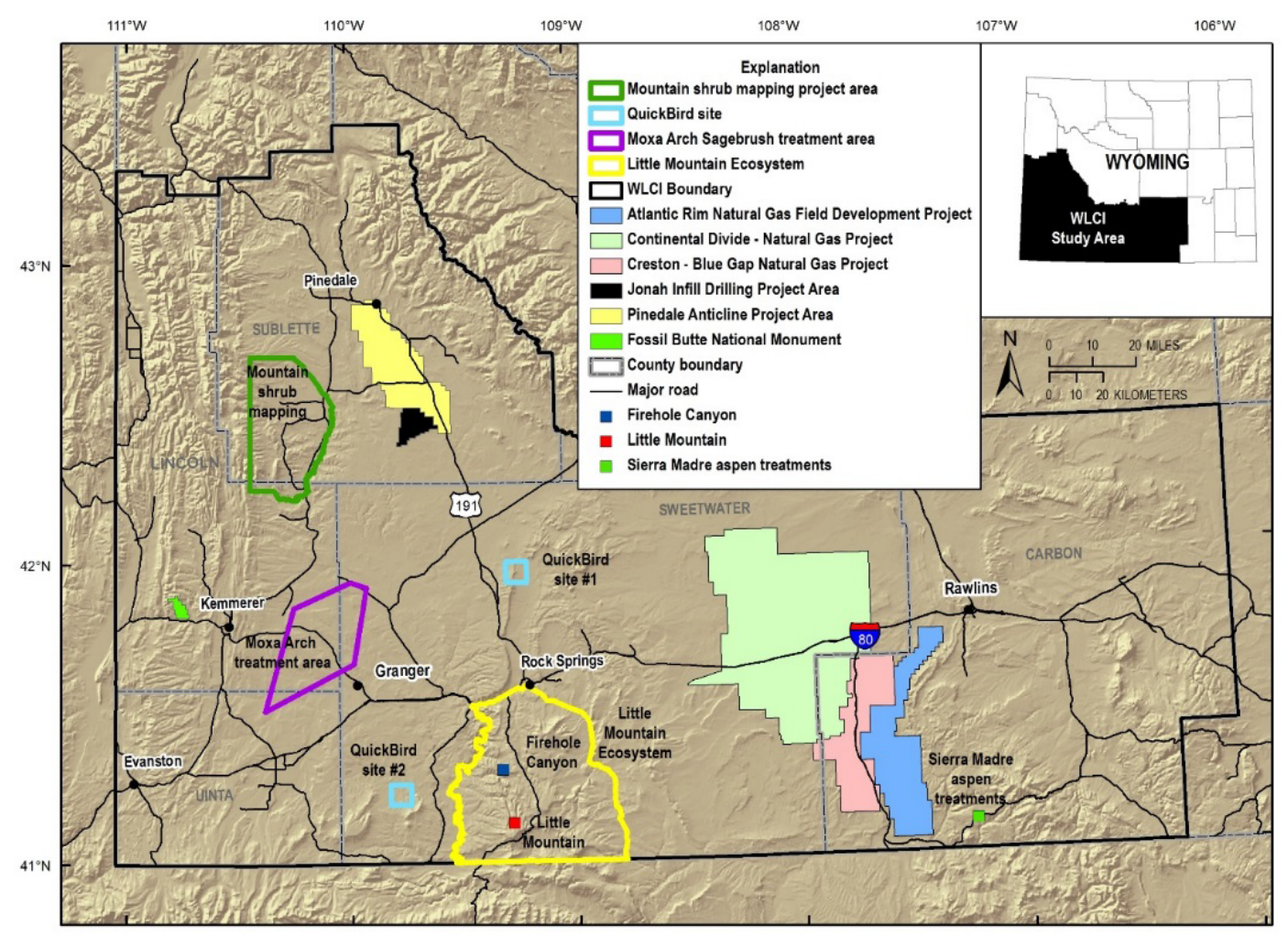

Figure 12. Locations of the U.S. Geological Survey's FY2015 field-based study areas associated with Effectiveness Monitoring activities and Mechanistic Studies of Wildlife in the Wyoming Landscape Conservation Initiative region.

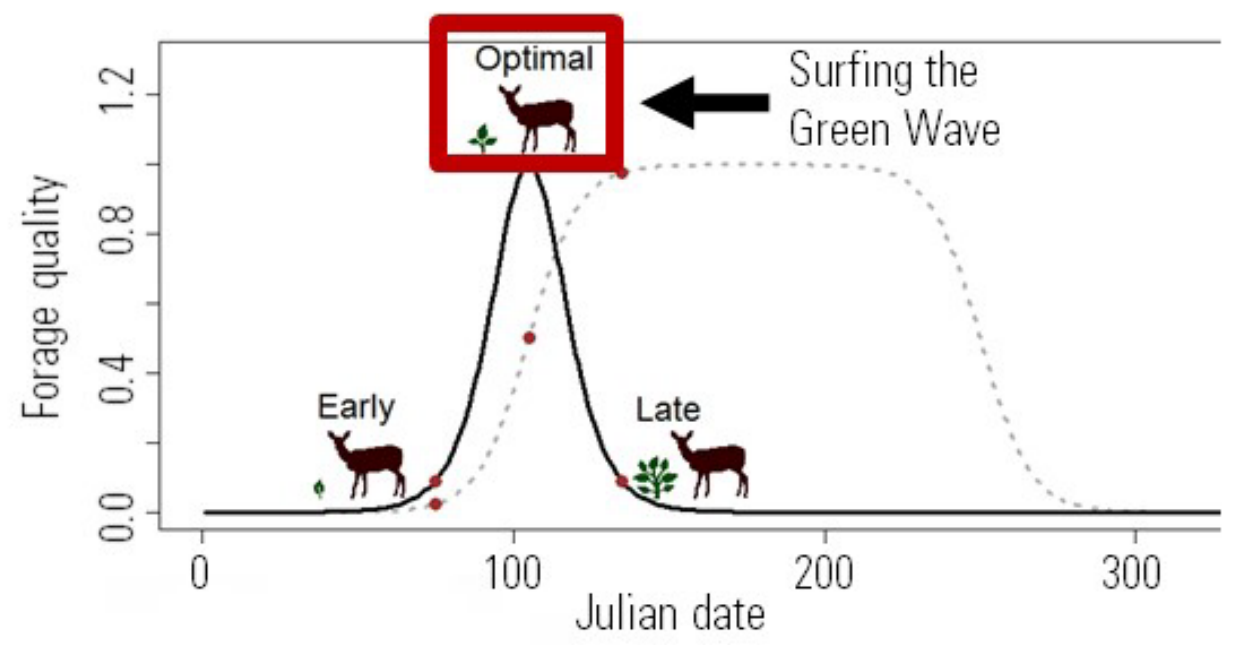

Figure 13. The instantaneous rate of greenup (IRG) (Bischof and others, 2012) is an indicator of forage quality. Deer using habitat at the peak of IRG are efficient green-wave surfers. During a dry year (2013) individual deer did not surf as well (Aikens and others, 2015). 


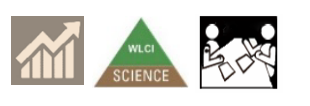 Mapping Mixed Mountain Shrub Communities to Support WLCI Conservation Planning and Effectiveness Monitoring of Habitat Treatments}

The mixed mountain shrub community, one of five WLCI focal vegetation communities, is associated with numerous WLCI conservation priority areas and habitat projects. The current extent, condition, and trends of mountain shrub patches, and mechanisms driving their condition, are unknown. Monitoring data from selected stands indicate an overall decline. Hypothesized causes of decline range from persistent drought to herbivory and, possibly, factors associated with increased energy resource development. Our long-term objectives are to map and measure the distribution and current condition of mixed mountain shrub communities and evaluate potential effects of habitat treatments (for example, projects to improve mule deer habitat), weather-related trends, increased energy resource development, and other change agents. Maps and other information from this work help to support WLCI partners with conservation planning and effectiveness monitoring of habitat treatments. Associated products and information are shared with WLCI partners during Local Project Development Team meetings.

We continue to record the presence of mixed mountain shrub communities in the Big Piney-La Barge Area identified in the Wyoming Range Mule Deer Habitat Plan (Damm and Randall, 2012). This area was selected to take advantage of existing assessment and monitoring data acquired by WLCI partners. Shrub presence data (fig. 14) were used with satellite imagery to build models of site (habitat) suitability for mountain shrub occurrence (Bowen and others, 2013; Chong and others, 2015), and spatial data collected in 2014 and 2015 were used to improve map products completed in 2013 (Bowen and others, 2013).

In FY2015, we continued assessing mahogany shrub community condition $(\mathrm{N}=, 45$ locations

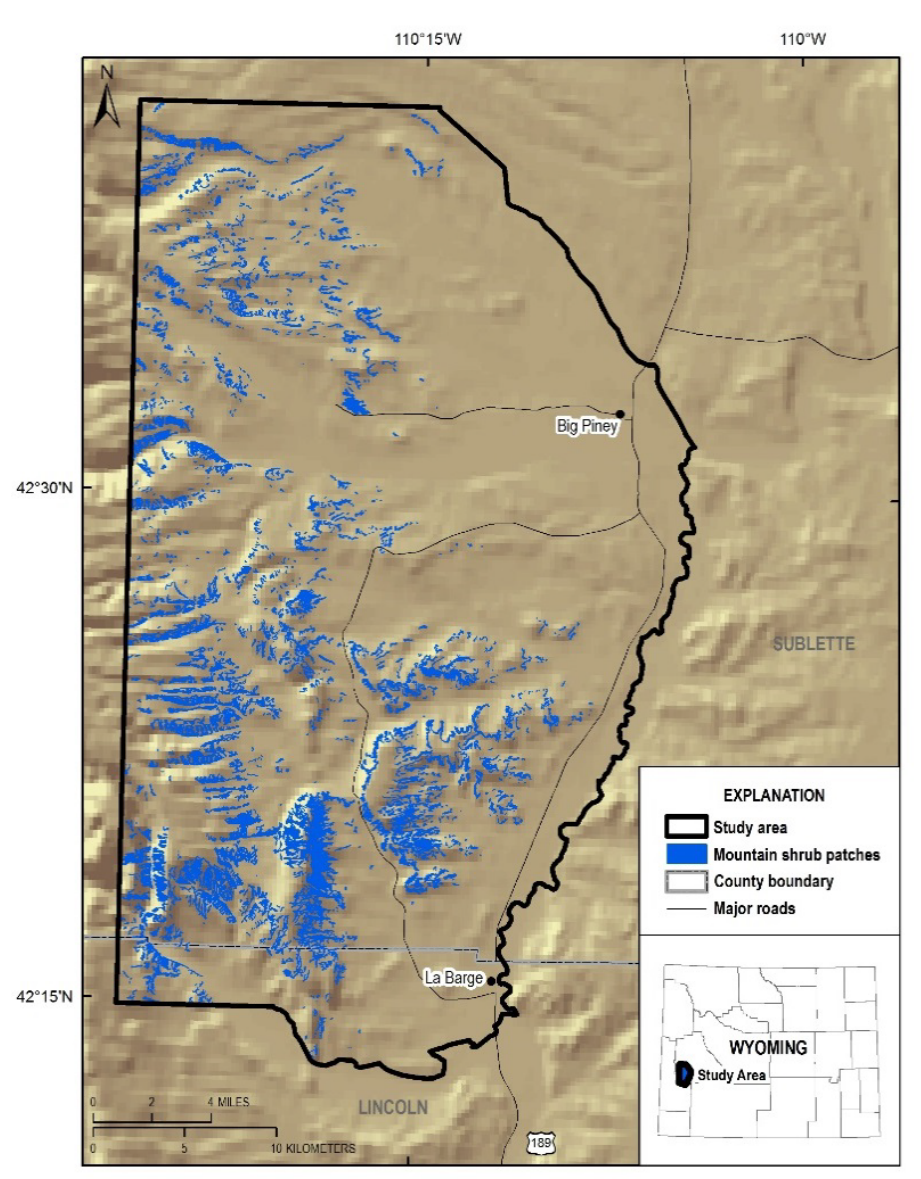
randomly selected from transitional and crucial winter range by distance from well pads). We quantified shrub foliar cover, density, herbivory, mortality, and age and size class structure. We also developed a protocol (for use in 2016) to determine whether growth and browsing histories can be reconstructed from previously collected stems (Bowen and others, 2014b).

Products Completed in FY2015

- Completed 2015 vegetation sampling database.

- Completed maps from the combined 2012-2015 field mapping efforts.

Contacts: Geneva W. Chong, 307-201-5425, geneva_chong@usgs.gov; Patrick J. Anderson, 970-226-9488, andersonpj@usgs.gov; Marie K. Dematatis, 970-226-9217, mdematatis@usgs.gov

Figure 14. Digitized mountain shrub patches in the Big Piney-La Barge area. Map credit: Marie Dematatis, Cherokee Nation Technologies, contracted to the U.S. Geological Survey. 


\section{Mandscape Assessment and Monitoring of Semi-Arid Woodlands in the Little Mountain Ecosystem}

The BLM and Wyoming Game and Fish Department regard the Little Mountain Ecosystem (LME) in southwestern Wyoming as a conservation priority. Since the mid-1990s, LME woodlands have been affected by several disturbance types, including wildfires and droughts. Management has included prescribed fire and mechanical thinning to rejuvenate decadent aspen stands and reduce conifer expansion in successional mixed-forest stands. To better understand disturbance effects on these woodlands, the BLM needs baseline information on these woodlands. Our goal is to provide that information, including woodland cover type and the extent, timing, and effects of various disturbance types on woodland productivity. A long-term objective of this work is to ascertain the feasibility of using archived satellite imagery to monitor abrupt and gradual changes in aspen forests and woodlands. Products will include datasets useful to the USGS and WLCI partners, and Local Project Development Teams may use the data to evaluate and prioritize aspen treatments. We are also using remote sensing to ascertain landscape-scale, long-term trends in woodland productivity, which will help to identify areas most susceptible to change. Finally, a broad aim of this work is to identify ecosystem response to disturbance and climate variability and to contribute to the literature of recent ecosystem change.

In FY2015, we analyzed previously collected data and completed a manuscript on the modeling portion of the project. We developed probability of occurrence models for deciduous and coniferous forest, and then combined model outputs into a field-validated, high-resolution synthetic map depicting forest cover type (Assal and others, 2015). This map provides managers with detailed information on the amount and pattern of LME forest cover, including the extent and patterns of both broad forest and small, isolated patches missed by regional land-cover data. The manuscript and data were made available to WLCI partners. In FY2016, we will complete the analysis and disseminate the results showing the extent, timing, and effect of drought on woodland productivity.

\section{Products Completed in FY2015}

- Assal, Timothy, and Sibold, Jason, 2014, Spatial and temporal analysis of drought impacts on semi-arid woodlands, 2014 ForestSAT Conference, Riva del Garda, Italy, November 4-7, 2014, at

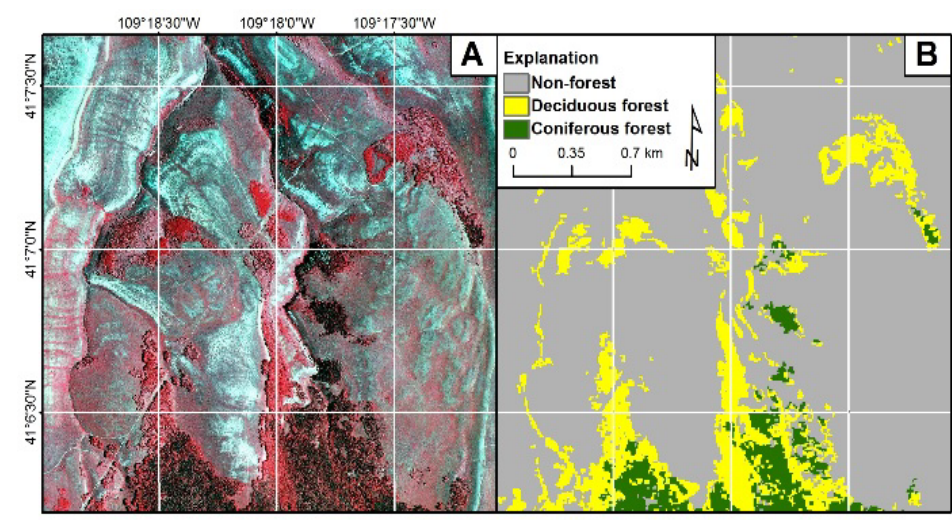

$A$ An infrared aerial photo depitcing a Little Mountain landscape. Dark red and black indicate coniferous forest; medium red indicates deciduous forest; other colors represent unforested habtiat. $B$ Synthesis map developed from model outputs. Map credit: Assal and others (2015).

http://ocs.agr.unifi.it/index.php/forestsat2014/ForestSAT2014/paper/view/230.

- Assal, T.J., Anderson, P.J., Sibold, J.S., 2015, Mapping forest functional type in a forest-shrubland ecotone using SPOT imagery and predictive habitat distribution modelling: Remote Sensing Letters, v. 6, p. 755-764, at http://www.tandfonline.com/doi/full/10.1080/2150704X.2015.1072289\#abstract.

- Assal, T.J., 2015, Mapping forest functional type in a forest-shrubland ecotone using SPOT imagery and predictive habitat distribution modelling (data): Remote Sensing Letter, v. 6, p. 755-764, at https://knb.ecoinformatics.org/\#view/doi:10.5063/F1639MP5.

Contacts: Timothy J. Assal, 970-226-9134, assalt@usgs.gov; Patrick J. Anderson, 970-226-9488, andersonpj@usgs.gov 


\section{Project Reports: Mechanistic Studies of Wildlife}

\section{T11 Modeling Habitat Associations and Distribution of Pygmy Rabbits}

The pygmy rabbit is a species of special concern throughout much of its range as a result of habitat loss and associated population declines. Information needs for the pygmy rabbit include the range of sagebrush habitat types the species inhabits, effects of landscape-scale habitat changes, and how natural gas development affects pygmy rabbit populations. Threats to pygmy rabbits include all forms of habitat loss and fragmentation in sagebrush systems. Pygmy rabbits are also occasionally observed in atypical habitats, and defining the range of sagebrush types and level of fragmentation that pygmy rabbits tolerate is crucial for guiding management decisions.

Generating data for addressing information needs is the goal of USGS pygmy rabbit research in Wyoming. In FY2015, we completed a study that defined marginal, intermediate, and high quality pygmy rabbit habitat in the BLM Kemmerer Field Office, and we generated a geographic information systems map identifying where each of these types of habitat occur. We completed analysis of our dataset relating pygmy rabbit occupancy and abundance to level of development on four major Wyoming gas fields, and we (with Steve Garman) conducted a simulation assessment of future oil and gas development scenarios on the distribution of pygmy rabbit habitat.

Our pygmy rabbit research in Wyoming has validated existing pygmy rabbit habitat maps, provided new distribution information, described variation in habitat quality, and provided information about the potential for spatial (overlap) conflicts between pygmy rabbits and both gas and wind energy resource development. We continue to study the statewide distribution of pygmy rabbits and their habitat associations. Collectively, this work will continue to provide resource managers with new information about pygmy rabbit distributions, habitat associations, and responses to existing and future energy resource development.

\section{Products Completed in FY2015}

- Germaine, S.S., Jarnevich, C.S., Ignizio, D.A., and Heyward, Joslin, Where are the pygmy rabbits? Modeling their distribution and characterizing habitat suitability in southwestern Wyoming, USA (in review).

Contact: Stephen S. Germaine, 970-226-9107, germaines@usgs.gov

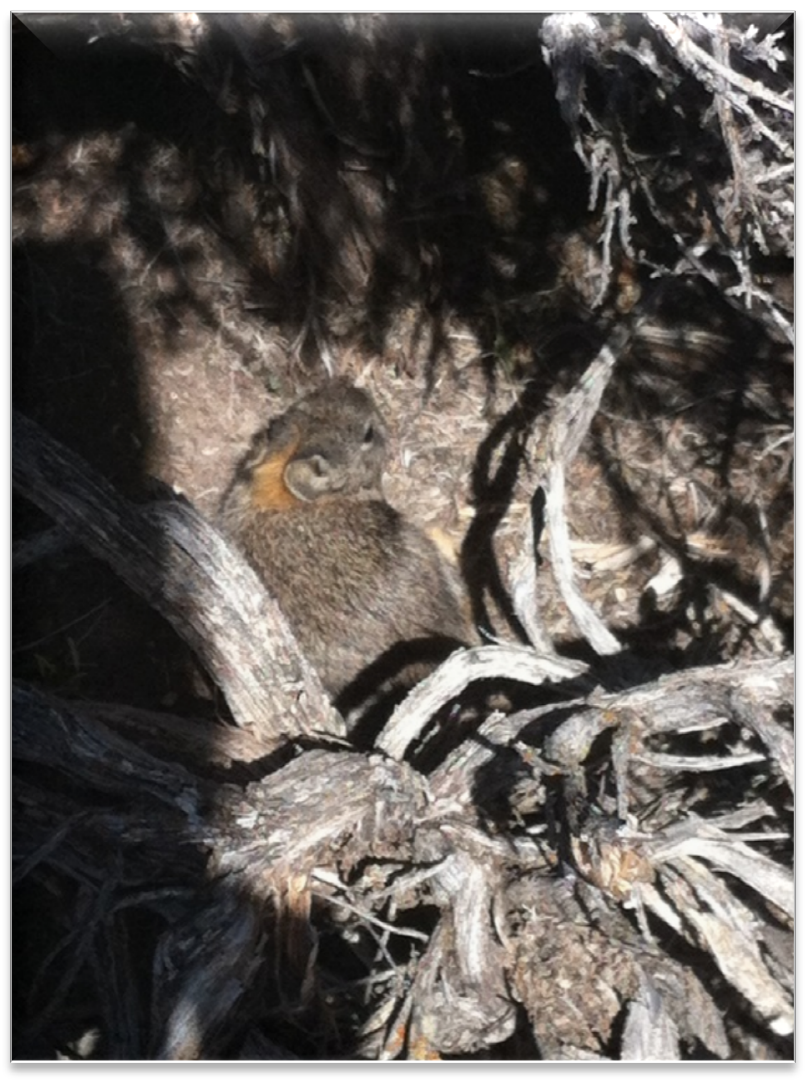

A juvenile pygmy rabbit hides under a big sagebrush plant. Photograph by Steve Germaine, U.S. Geological Survey. 


\section{Modeling Greater Sage-Grouse Population Responses to Landscape Changes}

The current focus of this project is to evaluate sage-grouse responses to landscape changes in Wyoming. This entails evaluating population-level responses, developing models to understand how population demographics and distributions are affected by changes, and assessing potential effects of future changes on sage-grouse resources and population viability. In FY2015, we evaluated the effect of lek count timing on estimates of population sizes and trends (Monroe and others, 2016), the results of which indicate that available data can be sampled from a larger time frame than used previously. We then conducted a population viability analysis that allowed us to compare population status across different management zones and within population clusters. Results indicate that most Wyoming populations are declining and population persistence partially depends on sage-grouse density. Earlier work also suggested that male lek attendance in Wyoming declined with increasing density of oil and gas development, with detectable effects up to 6.4 kilometers $(\mathrm{km})$ from a lek (Green and others, in review). Finally, we evaluated sage-grouse population trends relative to grazing intensity and timing. We found that in drier, low-productivity sites, sage-grouse populations increased if grazing was low intensity and early season (relative to peak normalized difference vegetation index), but negative effects of high-intensity grazing diminished at these ties as the season progressed. Conversely, in relatively moist, productive sites, sage-grouse populations declined if grazing was high intensity and late season.

We also developed a tool that synthesizes existing seasonal habitat models (O'Donnell and others, 2014) to help identify key factors limiting sage-grouse persistence in Wyoming. We further developed a new spatially explicit model that incorporated sage-grouse behavior, movements, and demographics to predict habitat use by allowing individual simulated grouse to move though and select habitat. The model allowed us to evaluate the spatial distribution and abundance of sage-grouse across Wyoming and within and outside of core areas. Results illustrate that although about 75 percent of birds occupy protected core areas in all life stages, significant population declines could occur outside of core areas, and the unprotected areas contribute to core and statewide populations. Landscape scenarios that simulate future energy resource development and climate-induced changes in WLCI sagebrush habitat are being incorporated into our spatially explicit population model to provide a better understanding of how these threats may affect long-term persistence of Wyoming's sage-grouse populations. Finally, we are completing several manuscripts for peer-reviewed journals. All of this research should set the foundation for long-term sage-grouse monitoring in Wyoming and possibly across the species' range.

\section{Products Completed in FY2015}

- O’Donnell, M.S., Aldridge, C.L., Fedy, B.C., and Doherty, K.E., 2015, Wyoming greater sage-grouse habitat prioritization-A collection of multi-scale seasonal models and geographic information systems land management tools: U.S. Geological Survey Data Series 891, 29 p., at http://dx.doi.org/10.3133/ds891.

- Monroe, A.P., Edmunds, D.R., and Aldridge, C.L., 2016, Effects of lek count protocols on greater sagegrouse population trend estimates: Journal of Wildlife Management, v. 80, no. 4, p. 667-668.

- Green, A.W., Aldridge, C.L., and O’Donnell, M.S., Investigating impacts of oil and gas development on greater sage-grouse using a Bayesian state-space model: Journal of Wildlife Management (in review).

- Final drafts of manuscripts for (1) PVA models based on lek counts; (2) effects of grazing on sagegrouse populations; and (3) population viability analyses models for sage-grouse across Wyoming and within the WLCI region to evaluate effects of future energy resource development and climate change.

Contact: Cameron L. Aldridge, 970-226-9433, aldridgec@usgs.gov 


\section{Mechanistic Understanding of Energy Resource Development Effects on Songbirds}

In the WLCI region, the quality of sagebrush habitats is a concern given the widespread extent of habitat conversion and alteration in sagebrush systems, in part the result of energy resource development. Three migratory songbird species are obligates of sagebrush shrublands: Brewer's sparrow, sagebrush sparrow, and sage thrasher, all of which are declining at least in parts of their range. In collaboration with the Wyoming Game and Fish Department, we initiated this multi-phase project to address the WLCI management need to identify the condition and distribution of sagebrush songbird habitats and key drivers of change in those habitats.

In Phase I (2008 to 2009), we documented decreasing nest survival of all three songbird species with increasing natural gas well density in the Jonah and Pinedale Anticline Project Area. In Phase II (2011 to 2012), we determined that the landscape variable of surrounding habitat loss was the best correlate of habitat change associated with natural gas development at our sites. We evaluated nest survival and the activity of important nest predators in relation to this metric. We identified nest predators using infrared nest cameras and conducted predator surveys across the energy resource development gradient. We have recorded 10 species depredating eggs and nestlings during 56 separate depredation events, 75 percent of which involved rodents. Chipmunk detections decreased with gas well density, whereas deer mouse and thirteen-lined and Unita ground squirrel detections increased, and nest survival of all 3 sagebrush-obligate songbirds species decreased with increased predator activity.

Collectively, our results suggest that natural gas development alters the local activity of rodent nest predators, thereby increasing the probability of nest predation. In FY2015, we continued monitoring nests and identifying predator species to ascertain the spatial and temporal consistency of our previous results. We also initiated Phase III which entails testing alternative hypotheses for why the activity and (or) abundance of key rodent nest predators increase along a gradient of increasing habitat loss associated with natural gas development. Specifically, we are conducting mark-recapture analyses of small mammals to test whether small mammal density increases with energy resource development, and testing whether a release from predation threat (raptors, canids, American badgers) and (or) local food augmentation may explain higher small mammal densities. Understanding specific mechanisms underlying effects of energy resource development on sagebrush songbirds will lead to more explicit management and mitigation recommendations for effectively maintaining songbird populations in the WLCI area and beyond, while also broadening our understanding of the Green River Basin ecosystem.

\section{Products Completed in FY2015}

- Hethcoat, M.G., and Chalfoun, A.D., 2015a, Energy development and avian nest survival in Wyoming, USA: a test of a common disturbance index: Biological Conservation, v. 184, p. 327-334.

- Hethcoat, M.G., and Chalfoun, A.D., 2015b, Toward a mechanistic understanding of humaninduced rapid environmental change: a case study linking energy development, nest predation, and nest predators: Journal of Applied Ecology v. 52, p. 1492-1499.

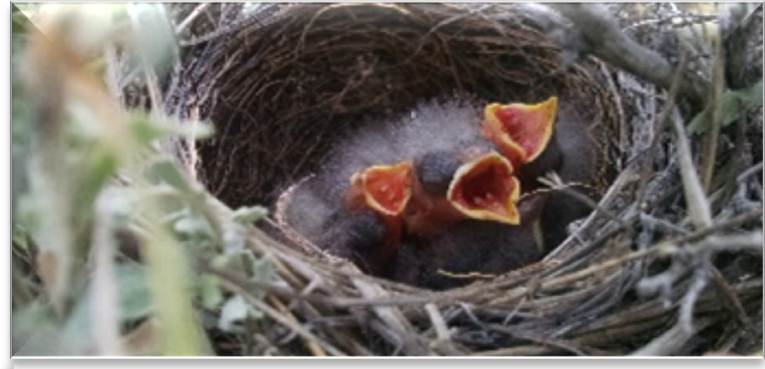

Brewer's sparrow nestlings in Pinedale Anticline area. Photograph by Lindsey Sanders, University of Wyoming.

Contacts: Anna D. Chalfoun, 307-766-6966, achalfou@uwyo.edu; Lindsey E. Sanders, 1sander7@uwyo.edu 


\section{Identifying Threshold Levels of Development that Impede Wyoming Mule Deer Migrations}

Migratory ungulates are susceptible to development along their migration routes. Understanding the influence of current development on migratory routes, including stopover sites used for foraging, can provide insights on the effects of future landscape changes. Impermeable barriers (like tall fences) have obvious and detrimental effects to migratory ungulates; however, the influence of semi-permeable barriers (like an energy field) — where connectivity is maintained, but the benefits of migration routes are compromised-remains unclear. We are using data collected from mule deer radio-marked with global positioning system collars to evaluate the influence of development on the migratory behavior of individual deer in western Wyoming. Specifically, we are evaluating the influence of development on movement rate, stopover use, and fidelity to migration routes for each individual, by season and year.

In FY2015, we completed analyses and concluded that deer avoided development when selecting stopover sites and spent 35 percent less time at stopovers affected by development. Fidelity to migration routes and stopover areas, as measured by the degree of spatial overlap between years, was not influenced by development except in one rapidly developed area (fig. 14). Overall, deer increased rate of movement, reduced length of time spent in stopover areas to forage, and shifted stopovers where development occurred rapidly on the landscape. Deer appear to mediate their exposure to development by altering movement (rates and timing) rather than through changes in routes, which could result in demographic consequences. This work adds to a growing number of studies indicating that development disrupts migrations. Distinguishing differences in the influence of development types holds promise to inform land-use planning decisions to support the management and conservation of migratory ungulates.

\section{Products Completed in FY2015}

- Wyckoff, T.B., 2015, Evaluating the influence of development on mule deer migrations: WyGISC Seminar Series, Laramie, Wyoming, October 23, 2015 [presentation].

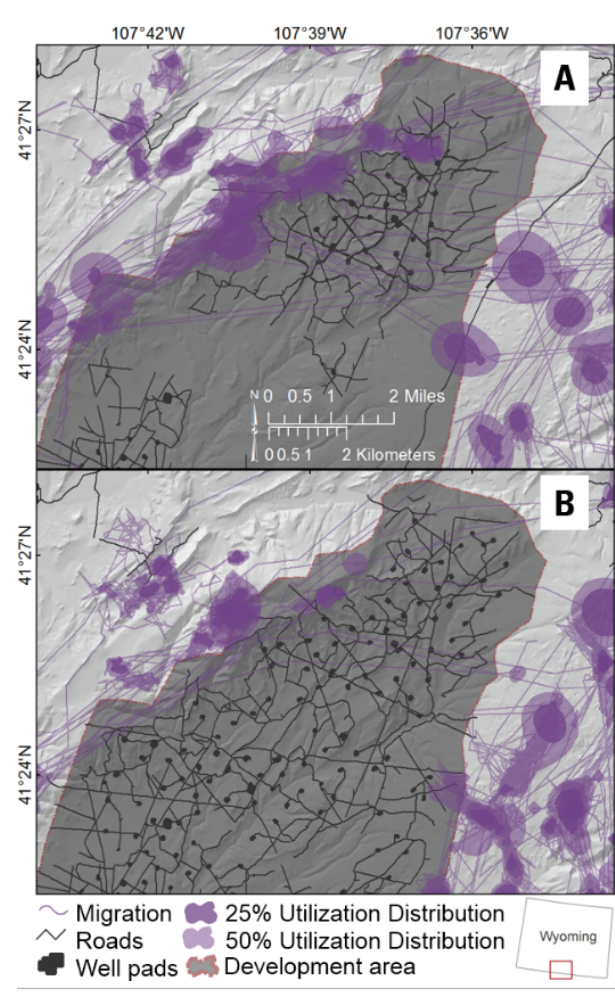

- Wyckoff, T.B., Kauffman, M.J., Sawyer, H., Albeke, S.E., and Garman, S.L., 2015, Evaluating the influence of development on ungulate migrations: The Wildlife Society Annual Conference, Winnipeg, Manitoba, October 21, 2015 [presentation].

- Wyckoff, T.B., 2015, Identifying threshold levels of development that impede Wyoming ungulate migrations: Annual Wyoming Cooperative Fish and Wildlife Unit Partners Meeting, Cheyenne, Wyoming, April 20, 2015 [presentation].

Contact: Matthew J. Kauffman; 307-766-5415; mkauffm1@uwyo.edu; Teal B.Wyckoff, wyckoff@uwyo.edu

Figure 15. Mule deer use of migration stopover sites (purple polygons; purple lines represent movements between sites) $A$, before and $B$, after rapid increase in development (black polygons and lines in gray shaded area) of the Atlantic Rim natural gas field in southwestern Wyoming. A Brownian Bridge Movement model was used to delineate stopover sites (dark and light purple: upper 25 and 50 percent of the utilization distribution, respectively). 


\section{Influence of Energy Resource Development on Native Fish Communities}

The rapid expansion of natural gas development in southwestern Wyoming has raised concerns about the effects for key wildlife species and habitats. Our goals are to (1) determine which habitat factors are driving fish species presence and abundance, and (2) evaluate the influence of oil and natural gas development on habitat quality, water quality, and fish communities in the Upper Green watershed. These investigations correspond to two of WLCI's management needs: (1) identify condition and distribution of key wildlife species/habitats, and species habitat requirements, and (2) evaluate wildlife and livestock responses to development. Our approach is a comparative study examining subwatersheds with differing levels of oil and gas development.

In FY2015, we analyzed data collected in the three previous years (led by Carlin Girard, formerly at University of Wyoming). We found that fish species' distributions are related to habitat characteristics. The presence of cutthroat trout and mottled sculpin were primarily associated with finescale habitat features, such as willow cover and substrate composition. Mountain sucker appeared to be more of a generalist with its distribution better explained by larger-scale landscape habitat features, such as slope and temperature. These differing habitat requirements contributed to varying vulnerability to oil and gas development. We also found variations in habitat and water quality related to oil and gas development. Our research suggests several avenues through which oil and gas development could be affecting stream ecosystems. Surface disturbance likely contributed to elevated suspended sediment concentrations and reduced willow cover, while spill history likely led to elevated stream polycyclic aromatic hydrocarbon concentrations. This knowledge can help land managers target their conservation efforts towards reducing sediment loads, maintaining stream cover, and reducing spills.

In FY2015, we also collected our fourth year of field data (led by Richard Walker, University of Wyoming). We continued to collect fish community data and monitor streamflow and temperature at Dry Piney and South Beaver Creek drainages (fig. 11), but we expanded our sampling to include more extensive hydrological characterization (in collaboration with Cheryl Miller at the USGS Wyoming-Montana Water Science Center), and we conducted preliminary sampling of resource availability and fish physiology to prepare for Phase II of this study, which will start in FY2016.

\section{Products Completed in FY2015}

- Girard, C.E., 2015, The effects of oil and natural gas development on water quality, aquatic habitat, and native fish in streams along the Wyoming Range: Laramie, Wyo., University of Wyoming, M.S. thesis, $101 \mathrm{p}$.

- Girard, C.E., and Walters, A.W., The differential sensitivity of native stream fishes to oil and natural gas development (in review).

- Girard, C.E., Farag, Aida, Alvarez, D., and Walters, A.W.,

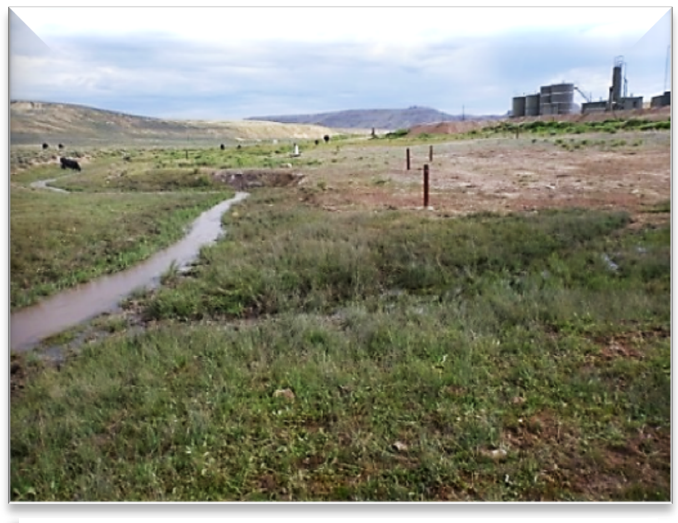

Dry Piney Creek winds through areas affected by oil and gas development in southwestern Wyoming. Photograph by Annika Walters, U.S. Geological Survey. Using multiple approaches to assess surface water characteristics of small streams in a southwestern Wyoming oil and gas field (in review).

- Walker, Richard, and Walters, A.W., 2015, Population dynamics of three fishes in relation to energy development in headwater streams of the Wyoming Range: Society for Freshwater Science annual meeting, May 17-21, Milwaukee, Wisc. [presentation].

Contact: Annika W. Walters, 307-766-5473, annika.walters@uwyo.edu 


\section{Project Reports: Data and Information Management}

\section{Data Management Framework and Catalog}

This project addresses the need to access, manage, and analyze WLCI data and information resources by providing online tools for (1) cataloging and archiving data and information, (2) discovering and using these resources, and (3) making the resources available to WLCI researchers, decisionmakers and the public through the WLCI Web site. The WLCI Data Catalog developed and hosted by the USGS is available at https://www.wlci.gov/tools-and-resources. It describes and provides access to datasets and project information associated with the WLCI. It is continuously maintained and updated to ensure that resources are current and relevant. The WLCI Data Catalog is built into the USGS ScienceBase infrastructure, which is a data cataloging and collaborative data management platform. This system has the capability to generate Web services that dynamically feed content into Web sites. This capability is used to provide content for WLCI Web tools, such as the WLCI Integrated Assessment, Long-Term Monitoring mapping tools, the Interactive Maps, and the Western Energy Citation Clearinghouse.

The myUSGS wiki system is another component of the Data Management Framework. It provides the WLCI community with tools for managing documents and materials associated with WLCI data and activities. The WLCI Coordination Team is using myUSGS to store, organize, and track information associated with WLCI habitat conservation projects. To meet WLCI communication needs, the USGS developed the WLCI Web site at www.wlci.gov, which provides information about ongoing activities and allows users to discover WLCI resources, including publications, newsletters, and information about both habitat conservation and science projects. With support from the USGS Data and Information Management Team, the WLCI Coordination Team and Communication Team manage the Web site's content. The Data and Information Management Team provides technical support for the Web site and helps the Coordination and Communication Teams to update Web site content. In FY2015, the foci of this project continued to include meeting communication needs, updating the WLCI Data Catalog, and providing access to WLCI data and project information.

\section{Products Completed in FY2015}

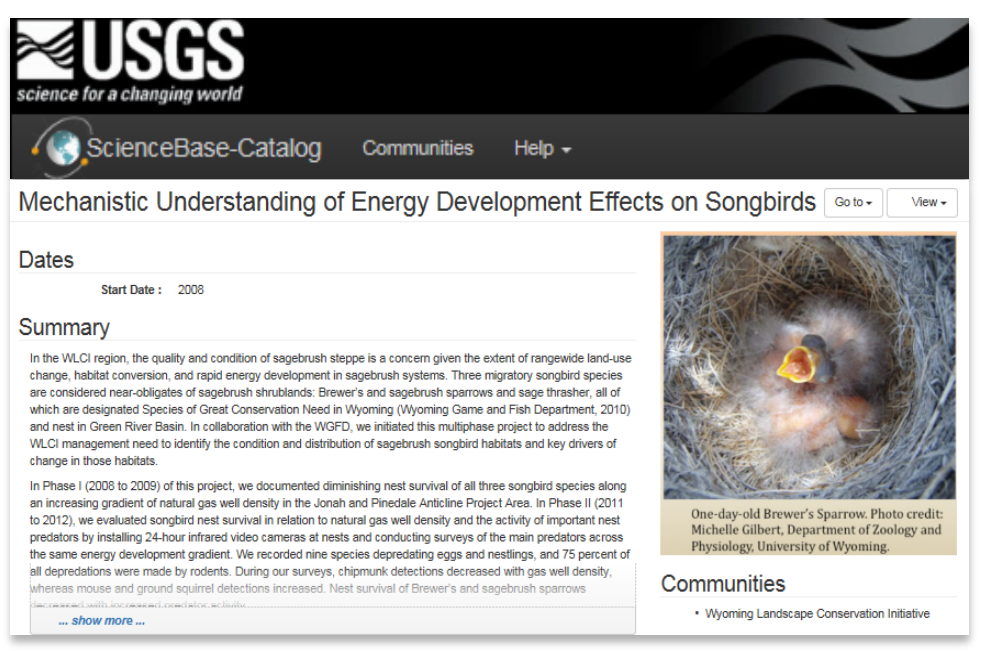

A screenshot from ScienceBase showing summary information on the U.S. Geological Survey's study to evaluate effects of energy resource development on songbird abundance, productivity, and predation.

- New and updated project information was added to the WLCI Data Catalog. The information was made available through the WLCI Web site, using Web services to dynamically display cataloged information.

- Content updates and technical support for the WLCI Web site.

Contact: Tamar Norkin, 303-202-4220, tnorkin@usgs.gov 
A primary objective of this project has been to develop visualization tools that display WLCI data products. This work increases ease of access and allows users to quickly and conveniently explore WLCI data. In previous years, we developed tools for viewing geospatial data in an interactive environment and for accessing data and data documentation. The tools include a set of three online map viewers provided through the WLCI Web site that display recently published USGS Data Series (see https://www.wlci.gov/wlciMapviewer/).

In FY2015, we replaced the datasets displayed in two of the map viewers with more recent datasets published by USGS scientists in 2014 and 2015. Specifics of the datasets now displayed in the map viewers are described below (the first two were those that were replaced in FY2015). We also updated the map viewer application to make it more interactive (for example, users now may select from three different base maps: a street map, satellite imagery, and a National Geographic map showing topographic features).

1. A digital representation of oil and natural gas well pad scars in southwestern Wyoming (Garman and McBeth, 2014) was replaced with the newer version (Garman and McBeth, 2015). It displays the locations of 15,532 oil and natural gas well pad scars. The map also shows another 1,872 possible oil and gas well pads (locations that lack documented well points in the vicinity), produced-water ponds associated with oil and gas extraction, and a category that includes storage tanks, compressors, and storage of oil and gas-related equipment.

2. The new map viewer displays oil and gas well data, a subset of the data published in, "Energy Map of Southwestern Wyoming, Part B-Oil and Gas, Oil Shale, Uranium, and Solar" (Biewick and Wilson, 2014). The oil and gas well data originated from the Wyoming Oil and Gas Conservation Commission and were processed by the U.S. Geological Survey to provide a historical perspective of drilling activity in the WLCI region. The uranium data display records from the U.S. Geological Survey's Mineral Resources Data System (MRDS) that relate to uranium resources in the WLCI region (fig. 15).

3. The new map viewer displays coal and wind energy production data, a subset of the $100+$ data layers published in, "Energy Map of Southwestern Wyoming, Part A-Coal and Wind" (Biewick and Jones, 2012). Data layers displayed in the viewer include wind turbines, electrical generating plants (differentiated by power source), industrial facilities using coal, electrical transmission lines, coal geological features, active surface and underground coal mines, abandoned mines, mine prospects, and mine permit areas.

\section{Products Completed in FY2015}

- Updated interactive map application on the WLCI Web site.

- New dataset added to map application, "Digital representation of oil and natural gas pad scars in Southwest Wyoming, 2012 update" (Garman and McBeth, 2015).

- New dataset added to map application, "Uranium, oil and gas development in southwestern Wyoming" (Biewick and Wilson, 2014).

Contact: Tamar Norkin, 303-202-4220, tnorkin@usgs.gov 

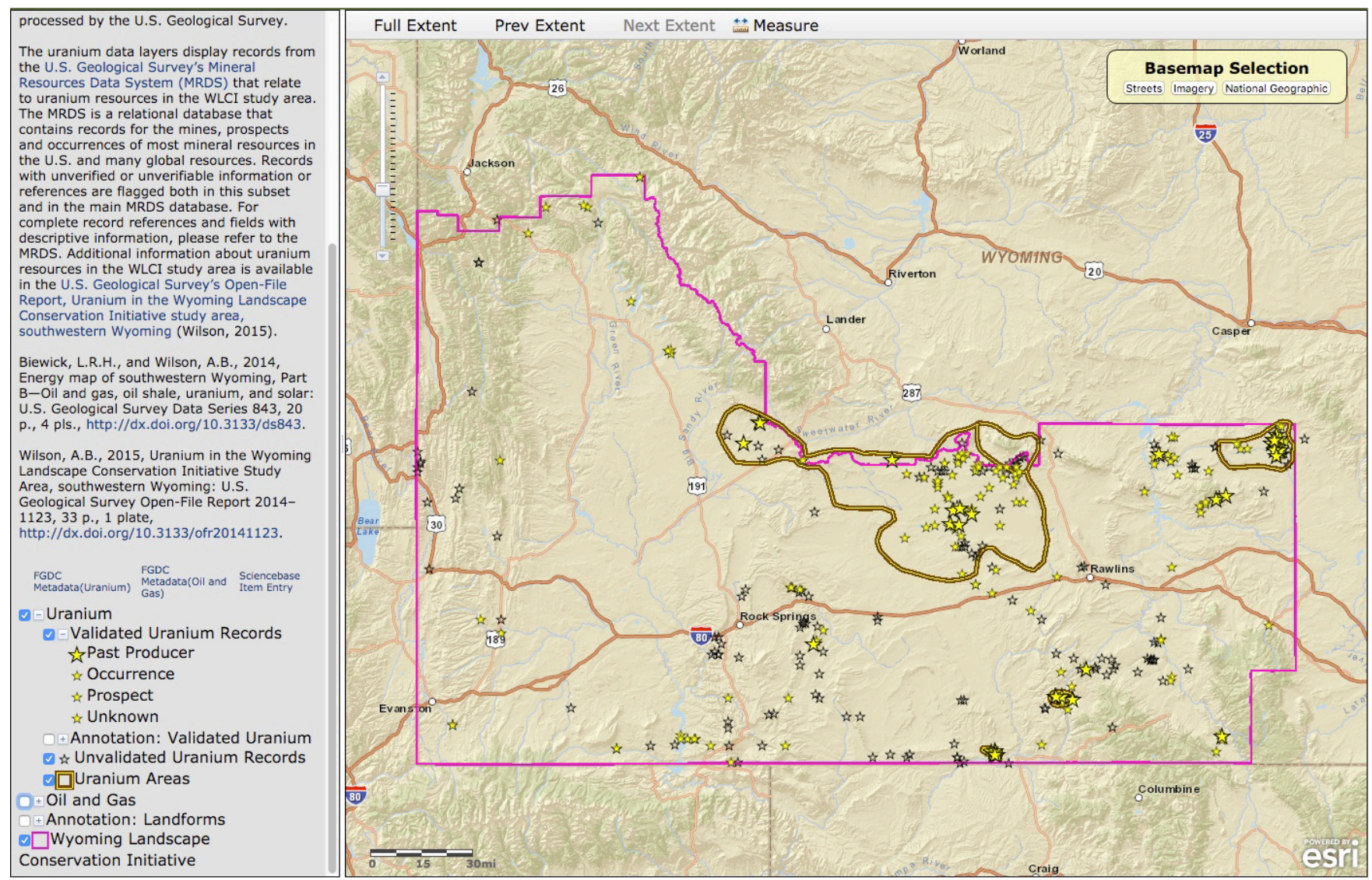

Figure 16. Screenshot showing one of the interactive energy maps on the Wyoming Landscape Conservation Initiative Web site. The map is titled, "Uranium, Oil and Gas Development in Southwestern Wyoming" and displays a subset of data from USGS Data Series 843 (Biewick and Wilson, 2014). It can be viewed online at https://www.wlci.gov/wlciMapviewer/maps/timeMap?map=EnergyOverTime. 


\section{References Cited and FY2015 WLCI Publications}

Aikens, E.O., Monteith, K.L., Merkle, J.A., Chong, Geneva, Dwinnell, Samantha, and Kauffman, M.J., 2015, Does drought affect the ability of migratory mule deer to surf the green wave?: 22nd Annual Conference of The Wildlife Society, Winnipeg, Manitoba, Canads, October, 17-21.

Assal, T.J., 2015, Mapping forest functional type in a forest-shrubland ecotone using SPOT imagery and predictive habitat distribution modelling (data): Remote Sensing Letter, v. 6, at https://knb.ecoinformatics.org/\#view/doi:10.5063/F1639MP5.

Assal, Timothy, and Sibold, Jason, 2014, Spatial and temporal analysis of drought impacts on semi-arid woodlands, 2014 ForestSAT Conference, Riva del Garda, Italy, November 4-7, 2014, at http://ocs.agr.unifi.it/index.php/forestsat2014/ForestSAT2014/paper/view/230.

Assal, T.J., Anderson, P.J., Sibold, Jason, 2015, Mapping forest functional type in a forest-shrubland ecotone using SPOT imagery and predictive habitat distribution modelling: Remote Sensing Letters, v. 6, p. 755-764, http://www.tandfonline.com/doi/full/10.1080/2150704X.2015.1072289\#abstract.

Assal, T.J., Anderson, P.J., and Sibold, Jason, 2016, Spatial and temporal trends of drought effects in a heterogeneous semi-arid forest ecosystem: Forest Ecology and Management, v. 365, p. 137-151, at http://dx.doi.org/10.1016/j.foreco.2016.01.017.

Bartos, T.T., Hallberg, L.L., and Eddy-Miller, C.A., 2015, Hydrogeology, groundwater levels, and generalized potentiometric-surface map of the Green River Basin lower Tertiary aquifer system, 2010-14, in the northern Green River structural basin, Wyoming: U.S. Geological Survey Scientific Investigations Report 2015-5090 33 p., at http://dx.doi.org/10.3133/sir20155090.

Biewick, L.R.H., and Jones, N.R., 2012, Energy map of southwestern Wyoming, Part A-Coal and wind: U.S. Geological Survey Data Series 683, 18 p., at http://pubs.usgs.gov/ds/683/.

Biewick, L.R.H., and Wilson, A.B., 2014, Energy map of southwestern Wyoming, Part B-Oil and gas, oil shale, uranium, and solar: U.S. Geological Survey Data Series 843, 20 p., 4 pls., at http://pubs.usgs.gov/ds/843/.

Bischof, R., Loe, L.E., Meisingset, E.L., Zimmerman, B., Van Moorter, B., and Mysterud, A., 2012, A migratory northern ungulate in the pursuit of spring: jumping or surfing the green wave?: American Naturalist, v. 180, no. 4, p. 407-424, at http://www.jstor.org/stable/10.1086/667590.

Bowen, Z.H., Aldridge, C.L., Anderson, P.J., Assal, T.J., Baer, L.A., Bristol, Sky, Carr, N.B., Chong, G.W. Diffendorfer, J.E., Fedy, B.C., Homer, S.L., Manier, D., Kauffman, M.J., Latysh, N., Melcher, C.P., Miller, K.A., Montag, J., and others, 2009, U.S. Geological Survey science for the Wyoming Landscape Conservation Initiative-2008 annual report: U.S. Geological Survey Open-File Report 2009-1201, 83 p., at http://pubs.usgs.gov/of/2009/1201/.

Bowen, Z.H., Aldridge, C.L., Anderson, P.J., Assal, T.J., Bartos, T.T., Biewick, L.R.H., Boughton, G.K., Chalfoun, A.D., Chong, G.W., Dematatis, M.K., Eddy-Miller, C.A., Garman, S.L., Germaine, S.S., Homer, C.G., Huber, Christopher, Kauffman, M.J., Latysh, Natalie, Manier, D.J., Melcher, C.P., Miller, A.R., Miller, K.A., Olexa, E.M., Schell, S.L., Walters, A.W., Wilson, A.B., and Wyckoff, T.B., 2015, U.S. Geological Survey science for the Wyoming Landscape Conservation Initiative2014 annual report: U.S. Geological Survey Open-File Report 2015-1091, 61 p., at http://dx.doi.org/10.3133/ofr20151091.

Bowen, Z.H., Aldridge, C.L., Anderson, P.J., Assal, T.J., Biewick, L.R.H., Blecker, S.W., Bristol, S., Carr, N.B., Chalfoun, A.D., Chong, G.W., Diffendorfer, J.E., Fedy, B.C., Garman, S.L., Germaine, S., Grauch, R.I., Holloway, J., Homer, C., Kauffman, M.J., Keinath, D., Latysh, N., Manier, D., McDougal, R.R., Melcher, C.P., Miller, K.A., Montag, J., Nutt, C.J., Potter, C.J., Sawyer, H., Schell, S., Shafer, S.L., Smith, D.B., Stillings, L.L., Tuttle, M., and Wilson, A.B., 2010, U.S. Geological 
Survey Science for the Wyoming Landscape Conservation Initiative-2009 Annual Report: U.S. Geological Survey Open-File Report 2010-1231, 106 p., at

http://pubs.usgs.gov/of/2010/1231/pdf/OF10-1231.

Bowen, Z.H., Aldridge, C.L., Anderson, P.J., Assal, T.J., Biewick, L.R.H., Blecker, S.W., Boughton, G.K., Bristol, S., Carr, N.B., Chalfoun, A.D., Chong, G.W., Clark, M.L., Diffendorfer, J.E., Fedy, B.C., Foster, K., Garman, S.L., Germaine, S., Holloway, J., Homer, C., Kauffman, M.J., Keinath, D., Latysh, N., Manier, D., McDougal, R.R., Melcher, C.P., Miller, K.A., Montag, J., Nutt, C.J., Potter, C.J., Schell, S., Shafer, S.L., Smith, D.B., Stillings, L.L., Tuttle, M., and Wilson, A.B., 2011, U.S. Geological Survey Science for the Wyoming Landscape Conservation Initiative-2010 Annual Report: U.S. Geological Survey Open-File Report 2011-1219, 146 p., at http://pubs.usgs.gov/of/2011/1219/.

Bowen, Z.H., Aldridge, C.L., Anderson, P.J., Assal, T.J., Biewick, L.R.H., Blecker, S.W., Boughton, G.K., Bristol, S., Carr, N.B., Chalfoun, A.D., Chong, G.W., Clark, M.L., Diffendorfer, J.E., Fedy, B.C., Foster, K., Garman, S.L., Germaine, S., Hethcoat, M.G., Holloway, J., Homer, C., Kauffman, M.J., Keinath, D., Latysh, N., Manier, D., McDougal, R.R., Melcher, C.P., Miller, K.A., Montag, J., Olexa, E.M., Potter, C.J., Schell, S., Shafer, S.L., Smith, D.B., Stillings, L.L., Sweat, M.J., Tuttle, M., and Wilson, A.B., 2013, U.S. Geological Survey science for the Wyoming Landscape Conservation Initiative-2011 annual report: U.S. Geological Survey Open-File Report 2013-1033, 145 p., at http://pubs.usgs.gov/of/2013/1033/OF13-1033_508.

Bowen, Z.H., Aldridge, C.L., Anderson, P.J., Assal, T.J., Bern, C.R., Biewick, L.R.H., Boughton, G.K., Carr, N.B., Chalfoun, A.D., Chong, G.W., Clark, M.L., Fedy, B.C., Foster, Katharine, Garman, S.L., Germaine, Stephen, Hethcoat, M.G., Homer, Collin, Kauffman, M.J., Keinath, Douglas, Latysh, Natalie, Manier, Daniel, McDougal, R.R., Melcher, C.P., Miller, K.A., Montag, Jessica, Potter, C.J., Schell, Spencer, Shafer, S.L., Smith, D.B., Sweat, M.J., and Wilson, A.B., 2014a, U.S. Geological Survey science for the Wyoming Landscape Conservation Initiative-2012 annual report: U.S. Geological Survey Open-File Report 2014-1093, 71 p, at http://pubs.usgs.gov/of/2014/1093/.

Bowen, Z.H., Aldridge, C.L., Anderson, P.J., Assal, T.J., Bern, C.R., Biewick, L.R.H., Boughton, G.K., Carr, N.B., Chalfoun, A.D., Chong, G.W., Dematatis, Marie, Fedy, B.C., Garman, S.L., Germaine, Stephen, Hethcoat, M.G., Homer, Collin, Huber, Christopher, Kauffman, M.J., Latysh, Natalie, Manier, Daniel, Melcher, C.P., Miller, K.A., Potter, C.J., Schell, S.L., Smith, D.B., Sweat, M.J., Walters, Annika, and Wilson, A.B., 2014b, U.S. Geological Survey science for the Wyoming Landscape Conservation Initiative-2013 annual report: U.S. Geological Survey Open-File Report 2014-1213, 60 p, at http://pubs.usgs.gov/of/2014/1213/.

Bowen, Z.H., Aldridge, C.L., Anderson, P.J., Chong, G.W., Drummond, M.A., Homer, C., Johnson, R.C., Kauffman, M.J., Knick, S.T., Kosovich, J.J., Miller, K.A., Owens, T., Shafer, S., and Sweat, M.J., 2009, U.S. Geological Survey science strategy for the Wyoming Landscape Conservation Initiative: U.S. Geological Survey Scientific Investigations Report 2008-5195, 26 p., at http://pubs.usgs.gov/sir/2008/5195/.

Chong, Geneva, Miller, Brian, Morisette, Jeffrey, Steltzer, Heidi, Bern, Carleton, Talbert, Marian, Talbert, Colin, and Shory, Rick, 2015, Use of PhenoCam data in a multi-scale evaluation of Wyoming sagebrush phenology: 2015 North Central Climate Science Center Open Science Conference, May 20-22, 2015, Fort Collins, Colo., at http://nccsc.colostate.edu/conference/program.

Clause, K.J., and Randall, Jill, 2014, Sagebrush die-off report: Natural Resources Conservation Service, Pinedale, Wyo., and Wyoming Game and Fish Department, Pinedale, Wyo., 57 p. 
Damm, Phillip, and Randall, Jill, 2012, Wyoming Range mule deer habitat management plan—Big Piney-LaBarge area: Pinedale, Wyo., Wyoming Game and Fish Department, Pinedale Regional Office, $71 \mathrm{p}$.

D’Erchia, Frank, editor, 2008, Wyoming Landscape Conservation Initiative Science Workshop Proceedings, May 15-17, 2007: U.S. Geological Survey Scientific Investigations Report 2008-5073, $96 \mathrm{p}$.

Fedy, B.C., Doherty, K.E., Aldridge, C.L., O’Donnell, Michael, Beck, J.L., Bedrosian, Bryon, Gummer, D.L., Holloran, M.J., Johnson, G.D., Kaczor, N.W., Kirol, C.P., Mandich, C.A., Marshall, David, McKee, Gwyn, Olson, Chad, Pratt, A.C., Swanson, C.C., and Walker, B.L., 2014, Habitat prioritization across large landscapes, multiple seasons, and novel areas-An example using greater sage-grouse in Wyoming: Wildlife Monographs, v. 190, no. 1, p. 1-39, at doi: 10.1002/wmon.1014.

Garman, S.L., 2015, Forecasting and evaluating patterns of energy development in southwestern Wyoming: WLCI Fact Sheet 7, 2 p., at http://pubs.usgs.gov/wlci/fs/7/.

Garman, S.L., and McBeth, J.L., 2014, Digital representation of oil and natural gas well pad scars in southwest Wyoming: U.S. Geological Survey Data Series 800, 7 p., at http://dx.doi.org/10.3133/ds800.

Garman, S.L., and McBeth, J.L., 2015, Digital representation of oil and natural gas well pad scars in southwest Wyoming - 2012 update [abs.]: U.S. Geological Survey Data Series 934, at http://dx.doi.org/10.3133/ds934.

Girard, C.E., 2015, The effects of oil and natural gas development on water quality, aquatic habitat, and native fish in streams along the Wyoming Range: Laramie, Wyo., University of Wyoming, M.S. thesis, $101 \mathrm{p}$.

Hethcoat, M.G., and Chalfoun, A.D., 2015a, Energy development and avian nest survival in Wyoming, USA: A test of a common disturbance index: Biological Conservation, v. 184, p. 327-334, at doi:10.1016/j.biocon.2015.02.009.

Hethcoat, M.G., and Chalfoun, A.D., 2015b, Toward a mechanistic understanding of human-induced rapid environmental change: a case study linking energy development, nest predation, and nest predators: Journal of Applied Ecology v. 52, p. 1492-1499, DOI: 10.1111/1365-2664.12513.

Homer, C.G., Xian, George, Aldridge, C.L., Meyer, D.K., Loveland, T.R., and O’Donnell, M.S., 2015, Forecasting sagebrush ecosystem components and greater sage-grouse habitat for 2050: Learning from past climate patterns and Landsat imagery to predict the future: Ecological Indicators, v. 55, p. 131-145, at http://dx.doi.org/10.1016/j.ecolind.2015.03.002.

Kenney, T.A., 2010, Levels at gaging stations: U.S. Geological Survey Techniques and Methods 3-A19, 60 p., at http://pubs.usgs.gov/tm/tm3A19/.

Miller, B., Chong, G., Steltzer, H., Aikens, E.O., and others, 2015, What you see depends on your point of view: comparison of greenness indices across spatial and temporal scales and what that means for mule deer migration and fitness: American Geologists Union Fall Meeting, San Francisco, Calif., December 14-18, 2015, at https://agu.confex.com/agu/fm15/meetingapp.cgi/Paper/82807.

Monroe, A.P., Edmunds, D.R., and Aldridge, C.L., 2016, Effects of lek count timing on greater sagegrouse population trend estimates: Journal of Wildlife Management, v. 4, p. 667-668, DOI: 10.1002/jwmg.1050.

O’Donnell, M.S., Aldridge, C.L., Fedy, B.C., and Doherty, K.E., 2015, Wyoming greater sage-grouse habitat prioritization-A collection of multi-scale seasonal models and geographic information systems land management tools: U.S. Geological Survey Data Series 891, 28 p., at http://dx.doi.org/10.3133/ds891. 
Sauer, V.B., and Turnipseed, D.P., 2010, Stage measurement at gaging stations: U.S. Geological Survey Techniques and Methods book 3, chap. A7, 45 p. [Also available at http://pubs.usgs.gov/tm/tm3-a7/.] Sweet, S.K., Griffin, K.L., Steltzer, Heidi, Gough, Laura, and Boelman, N.T., 2015, Greater deciduous shrub abundance extends tundra peak season and increases modeled net $\mathrm{CO}_{2}$ uptake: Global Change Biology, v. 21, p. 2394-2409, at http://onlinelibrary.wiley.com/doi/10.1111/gcb.12852/abstract.

Turnipseed, D.P., and Sauer, V.B., 2010, Discharge measurements at gaging stations: U.S. Geological Survey Techniques and Methods book 3, chap. A8, 87 p., at http://pubs.usgs.gov/tm/tm3-a8/.

U.S. Geological Survey, variously dated, National field manual for the collection of water-quality data: U.S. Geological Survey Techniques of Water-Resources Investigations, book 9, chaps., A1-A9, unpaged, at http://pubs.water.usgs.gov/twri9A.

Wagner, R.J., Boulger, R.W., Jr., Oblinger, C.J., and Smith, B.A., 2006, Guidelines and standard procedures for continuous water-quality monitors - Station operation, record computation, and data reporting: U.S. Geological Survey Techniques and Methods 1-D3, 51 p. and 8 attachments, at http://pubs.water.usgs.gov/tm1d3.

Walker, R., and Walters, A.W., 2015, Population dynamics of three fishes in relation to energy development in headwater streams of the Wyoming Range: Society for Freshwater Science annual meeting, May 17-21, Milwaukee, Wisc. [Presentation].

Wheeler, J.D., and Eddy-Miller, C.A., 2005, Seepage investigation on selected reaches of Fish Creek, Teton County, Wyoming, 2004: U.S. Geological Survey Scientific Investigations Report 2005-5133, 20 p., at http://pubs.usgs.gov/sir/2005/5133/.

Wilson, A.B., 2015, Uranium in the Wyoming Landscape Conservation Initiative study area, southwestern Wyoming: U.S. Geological Survey Open-File Report 2014-1123, at http://dx.doi.org/10.3133/ofr20141123.

Wyckoff, T.B., 2015, Evaluating the influence of development on mule deer migrations: WyGISC Seminar Series, Laramie, Wyo., October 23, 2015.

Wyckoff, T.B., 2015, Identifying threshold levels of development that impede Wyoming ungulate migrations, Annual Wyoming Cooperative Fish and Wildlife Unit Partners Meeting, Cheyenne, Wyo., April 20, 2015 [Presentation].

Wyckoff, T.B., Kauffman, M.J., Sawyer, H., Albeke, S.E., and Garman, S.L., 2015, Evaluating the influence of development on ungulate migrations: The Wildlife Society Annual Conference, Winnipeg, Manitoba, October 21, 2015.

Wyoming Game and Fish Department, 2010, Wyoming State wildlife action plan: Cheyenne, Wyo., Wyoming Game and Fish Department, unpaged. 

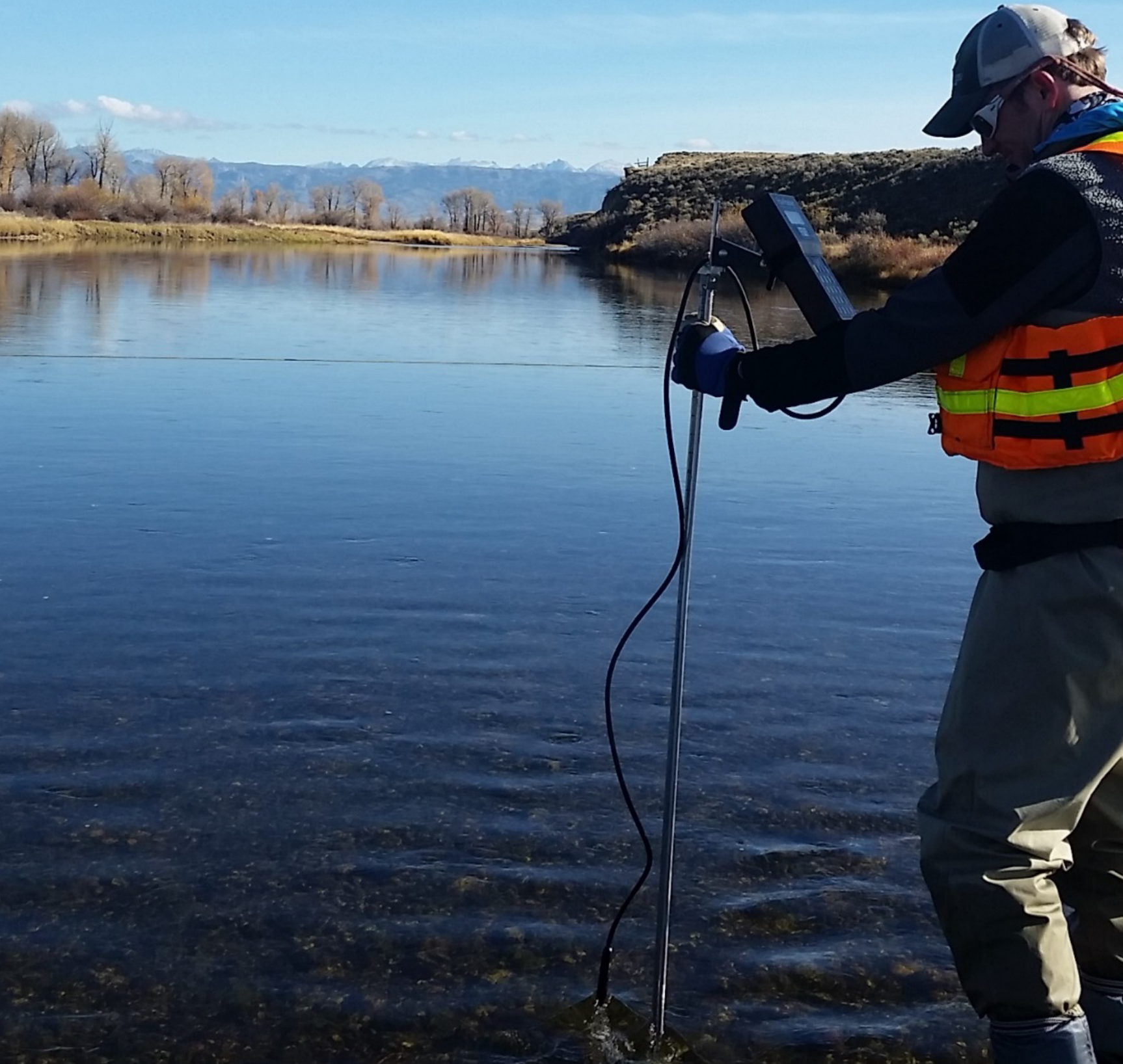